PNL-10839

UC-602

\title{
Sitewide Feasibility Study. Eielson Air Force Base, Alaska
}
G. V. Last
D. C. Lanigan
G. B. Josephson
L. M. Bagaasen

September 1995

\section{Prepared for}

the U.S. Department of Energy

under Contract DE-AC06-76RLO 1830

Pacific Northwest Laboratory

Richland, Washington 99352 


\section{DISCLAIMER}

This report was prepared as an account of work sponsored by an agency of the United States Government. Neither the United States Government nor any agency thereof, nor any of their employees, make any warranty, express or implied, or assumes any legal liability or responsibility for the accuracy, completeness, or usefulness of any information, apparatus, product, or process disclosed, or represents that its use would not infringe privately owned rights. Reference herein to any specific commercial product, process, or service by trade name, trademark, manufacturer, or otherwise does not necessarily constitute or imply its endorsement, recommendation, or favoring by the United States Government or any agency thereof. The views and opinions of authors expressed herein do not necessarily state or reflect those of the United States Government or any agency thereof. 


\section{DISCLAIMER}

Portions of this document may be illegible in electronic image products. Images are produced from the best available original document. 


\section{EXECUTIVE SUMMARY}

\section{INTRODUCTION}

The Sitewide Feasibility Study (FS) is required under the Comprehensive Environmental Response, Compensation, and Liability Act (CERCLA), the National Contingency Plan (NCP), and the Federal Facility Agreement (FFA) for Eielson Air Force Base (AFB). It is based on findings presented in the Sitewide Remedial Investigation (RI) Report (USAF 1995a), and the Sitewide Baseline Risk Assessment (BLRA) Report (USAF 1995b).

Under the FFA, 64 potential source areas were placed in one of six operable units, based on similar contaminant and environmental characteristics, or were included for evaluation under a Source Evaluation Report (SER). The sitewide RI was directed at contamination that was not confined to an operable unit (OU) or SER source area. The objectives of the sitewide RI were to:

- provide information about site characteristics to support individual OU RI/FS efforts and the sitewide RI/FS, including site hydrogeology and determination of background soil and groundwater characteristics;

- identify and characterize contamination that is not confined or attributable to a specific source area through sitewide monitoring of groundwater and surface water;

- evaluate cumulative risks to human health and the environment from contamination on a sitewide basis; and

- provide a mechanism for continued cohesive sitewide monitoring.

To ensure that offsite communities are not negatively affected by site contamination, several surface water bodies and the North Boundary wells were monitored for contamination. The North Boundary Wells were sampled to monitor groundwater quality downgradient of the developed portion of the base. The surface water bodies investigated included: Garrison Slough, French Creek, Moose Creek, Piledriver Slough, Flightline Pond, and Lily Lake.

Results from the sitewide remedial investigation and baseline risk assessment indicate that polychlorinated biphenyl (PCB) contamination found in Garrison Slough presents an increased risk to human health through the ingestion of contaminated fish. All other areas addressed by the sitewide investigation have been determined to present an acceptable risk to human health and the environment (USAF 1995b). Thus, this FS focuses on the evaluation of technologies and alternatives for remediation of the aquatic sediments and fish populations occupying Garrison Slough.

\section{GARRISON SLOUGH CONTAMINATION}

Garrison Slough runs through the developed portion of the base and is adjacent to 16 potential contaminant source areas. It receives most of the surface runoff from the developed portion of the base, and may also receive contaminated groundwater from several source areas.

Fuel-related volatile organics, chlorinated solvents, and pesticides were detected at low concentrations $\left(<2 \mu \mathrm{g} / \mathrm{L}\right.$ ) in surface water. Pesticides up to $11,000 \mu \mathrm{g} / \mathrm{kg}$ of $4,4^{\prime}-D D D$, diesel range 
organics (DRO) up to $38 \mathrm{mg} / \mathrm{kg}$, and PCBs up to $55,000 \mu \mathrm{g} / \mathrm{kg}$ were detected in sediments. Concentrations of metals in the surface water and sediment were generally within the ranges of background values for groundwater and soil on the base (PNL 1994a).

Sediment samples collected in 1994 confirmed the presence of PCBs (found in an earlier investigation), with the maximum concentration measured $300 \mathrm{~m}$ (328 yd) upstream of Arctic Avenue. PCBs were below detection limits in samples collected further upstream. Approximately $240 \mathrm{~m}$ (263 yd) downstream, the PCB concentration dropped by an order of magnitude to $3200 \mu \mathrm{g} / \mathrm{kg}$. Another $470 \mathrm{~m}(514$ yd) further downstream, the PCB concentration dropped another order of magnitude to $130 \mu \mathrm{g} / \mathrm{kg}$. The PCB concentration remained at this same order of magnitude near Transmitter Road. This PCB contamination appears to have originated from a point source just south of the Base Civil Engineering Maintenance Shop (perhaps from surface runoff or a past incidental spill).

Results from the BLRA indicate that ingestion and dermal contact with the sediment presents an acceptable risk. However, PCB concentrations in fish occupying lower Garrison Slough pose an excess cancer risk on the order of $10^{-3}$, using a recreational land-use scenario. Thus, this stretch of the slough is being considered for remedial action.

\section{REMEDIAL ACTION OBJECTIVES}

Remedial action objectives (RAOs) have been developed for lower Garrison Slough based on the general remediation goals defined by CERCLA, the NCP criteria for acceptable risk, and the applicable or relevant and appropriate regulatory requirements (ARARs). The primary goal of remediation is to reduce the potential risk to human health from the consumption of PCBcontaminated fish. This goal can be achieved by:

- Preventing ingestion of contaminated fish from lower Garrison Slough, and

- Reducing the highest concentrations and mass of PCBs available for uptake by water column organisms, including fish, so that fish tissue concentrations of PCBs will eventually achieve acceptable levels.

No direct relationship can be quantified between sediment PCB concentrations and resultant fish tissue concentrations in lower Garrison Slough. However, fish tissue samples with the highest levels of PCBs were collected from areas in the slough with the highest PCB sediment contamination. Thus, a preliminary remediation goal for sediment was developed based on removing most of the mass of PCBs. This approach assumes that removing or isolating the sediment with the highest PCB concentrations and reducing the overall mass available for uptake by water column organisms would, over time, lead to a reduction in the average PCB fish tissue concentration. The RAOs are shown in Table ES.1.

\section{Alternatives}

Potential remedial response actions, remedial technologies, and process options were screened to identify the most reasonable actions for fish and aquatic sediments. Alternatives were developed by combining the selected technologies for individual media into comprehensive cleanup alternatives. The alternatives were screened based on a preliminary evaluation of effectiveness, implementability, and cost. Five basic alternatives were retained for further evaluation. They 
Table ES.1. Remedial Action Objectives

\begin{tabular}{||l|l|l|l|l||}
\hline Medium & \multicolumn{1}{|c|}{$\begin{array}{c}\text { Contaminant of } \\
\text { Concern }\end{array}$} & \multicolumn{1}{|c|}{$\begin{array}{c}\text { Exposure } \\
\text { Route }\end{array}$} & \multicolumn{1}{|c|}{$\begin{array}{c}\text { Preliminary } \\
\text { Remediation Goal }\end{array}$} \\
\hline \hline Fish & $\begin{array}{l}\text { PCBs } \\
\text { (Aroclor 1260) }\end{array}$ & Food Chain & Human & $\begin{array}{l}0.69 \mu \mathrm{g} / \mathrm{kg}^{(\mathrm{a})} \\
\text { (wet weight) }\end{array}$ \\
\hline Sediment & $\begin{array}{l}\text { PCBs } \\
\text { (Aroclor 1260) }\end{array}$ & Food Chain & $\begin{array}{l}\text { Human } \\
\text { (through fish } \\
\text { intake) }\end{array}$ & $\begin{array}{l}\text { Reduce the peak concen- } \\
\text { trations and a prepon- } \\
\text { derance of the PCB mass }\end{array}$ \\
\hline \hline $\begin{array}{l}\text { (a) Based on a back calculation for the fish tissue concentration that would produce a total } \\
\text { excess cancer risk of less than 10-8 } \text { (recreational exposure). }\end{array}$ \\
\hline
\end{tabular}

include the No Action alternative, a Limited Action alternative, a containment alternative (In Situ Cappingl, and two removal alternatives (Dredge and Dispose, and Dredge and Treat). Each of these alternatives is briefly described in the following paragraphs.

\section{No Action Alternative}

The No Action alternative is required under the NCP to provide a baseline against which other alternatives can be compared. Under this alternative, no further remedial action would be taken. However, environmental monitoring of fish and sediment would be conducted to assess the progress of natural attenuation.

\section{Limited Action Alternative}

The Limited Action alternative would use institutional controls to limit current and future ingestion of contaminated fish, and engineering controls to inhibit the migration of fish into contaminated reaches of the slough. A fish advisory or Catch-and-Release-only restrictions would be promulgated be the Alaska State Department of Fish and Game. A rock dam would be constructed downstream from Arctic Avenue to prevent fish from migrating into the contaminated portion of the slough. Monitoring and annual maintenance would be performed to ensure the integrity of the rock dam. Fish and sediment concentrations and distributions would be monitored to track performance of this remedial action.

\section{In Situ Capping Alternative}

The In Situ Capping alternative would use temporary institutional controls to limit current ingestion of contaminated fish, and would cap a preponderance of the PCB sediment contamination to inhibit its bioaccumulation in the fish population. A temporary fish advisory or Catch-and-Release-only restrictions would be promulgated by the Alaska State Department of Fish and Game. When the PCB concentrations in the fish population have decreased to RAO levels, the fishing advisory/ restrictions would be lifted.

A 300-m (1000 ft) long stretch of lower Garrison Slough, immediately upstream of Arctic Avenue, would be lined with a multilayer cap to isolate PCB contaminated sediment from the ecosystem. This portion of the slough contains $\sim 80 \%$ of the mass of the PCB contamination found in the entire slough. Capping would be performed in late summer when surface water flows are their lowest, 
and the groundwater table is near its deepest. Surface water would be routed around the capping area to reduce the potential for sediment resuspension and transport, and to make installation of the liner less complicated. After minimal preparation of the stream bed (devegetation and contouring), a permeable geotextile liner would be installed, and covered by successive 10-15 cm (4-6 in.) thick layers of pea gravel; $5 \mathrm{~cm}$ diam. very coarse pebble $(2$ in. drain rock), and finally 5 to $15 \mathrm{~cm}$ diam. small cobble (2-6 in. rock). The complete liner is estimated to raise the bed of the slough 30 to $45 \mathrm{~cm} \mathrm{(12} \mathrm{to} 18 \mathrm{in}$.). Periodic maintenance would be required to maintain the integrity of the cap. Monitoring of fish and downstream sediment concentrations would be performed to ensure the performance of the remedial action.

\section{Dredge and Dispose Alternative}

The Dredge and Dispose alternative would use temporary institutional controls to limit current ingestion of contaminated fish, remove a preponderance of the PCB contamination, and dispose of the contaminated sediment on base. A temporary fish advisory or Catch-and-Release-only restrictions would be promulgated, as in the In Situ Capping alternative.

A preponderance of PCB contamination in the sediment would be removed by mechanically dredging approximately $300 \mathrm{~m}(1000 \mathrm{ft})$ of Garrison Slough immediately upstream of Arctic Avenue. This portion of the slough contains $-80 \%$ of the mass of the PCB contamination. Dredging activities would be performed in late summer when surface water flows are their lowest, and the groundwater table is near its deepest. Surface water would be routed around the targeted dredging area to reduce the potential for sediment resuspension and transport, and to reduce the amount of water picked up during the dredging operation. A large backhoe would excavate the sediment to a depth of approximately $0.6 \mathrm{~m}(2 \mathrm{ft})$ plus a $10 \%$ over dig. This operation would produce an estimated $660 \mathrm{~m}^{3}$ (860 cu yd) of dredged material which would be placed into dump trucks. The dredged sediment would then be hauled to an on-base landfill and disposed directly to an unlined trench, covered with native soils, and revegetated. The use of a hydraulic dredge was also evaluated, but would produce a high water-to-solids ratio, necessitating the treatment of large amounts of water. Monitoring of fish and downstream sediment concentrations would be performed to ensure the performance of the remedial action.

\section{Dredge and Treat Alternative}

The Dredge and Treat alternative would use temporary institutional controls to limit current ingestion of contaminated fish, remove a preponderance of the PCB contamination, and treat the contaminated sediment on base. A temporary fish advisory or Catch-and-Release-only restrictions would be promulgated as in previous alternatives.

A preponderance of PCB contamination in the sediment would be removed, as in the Dredge and Dispose alternative. The dredged material would be hauled to an existing on-base land farming facility. The dredge material would be evenly spread over a $15 \mathrm{~cm}(12$ in.) thick bed of soil amendments (straw or sawdust) and inoculated with white rot fungus (Phanerocheate Chrysosporium) and nutrients. The sediment, soil amendments, and nutrients would then be tilled and evenly mixed. The addition of soil amendments is estimated to increase the volume of the waste materials by a factor of 2. Land farming would degrade the PCBs to carbon dioxide over several months to years. Following treatment, the clean soil would be left in place. Monitoring of fish and downstream sediment concentrations would be performed to ensure the performance of the remedial action. 


\section{EVALUATION}

A detailed analysis of the remedial alternatives was conducted to evaluate each potential alternative against the seven NCP criteria. A comparative analysis was also made using the five NCP balancing criteria. A visual presentation of the comparative analysis is shown in Table ES.2. The estimated cost for each alternative is presented in Table ES.3.

The individual analyses indicated the No Action alternative would not achieve the RAOs, at least not for tens of years (via natural attenuation).

The Limited Action alternative would rely on institutional controls to meet the RAO for fish tissue. However, it would not meet the RAO for sediment (except through natural attenuation). The rock dam would essentially eliminate the upper reaches of the slough for spawning and other productive use.

Table ES.2. Comparison of Remedial Action Alternatives Using the Five Balancing Criteria

\begin{tabular}{|c|c|c|c|c|c|}
\hline Criterion & No Action & $\begin{array}{l}\text { Limited } \\
\text { Action }\end{array}$ & $\begin{array}{l}\text { In Situ } \\
\text { Capping }\end{array}$ & $\begin{array}{c}\text { Dredge } \\
\text { and } \\
\text { Dispose }\end{array}$ & $\begin{array}{c}\text { Dredge } \\
\text { and } \\
\text { Treat }\end{array}$ \\
\hline $\begin{array}{l}\text { Long-Term } \\
\text { Effectiveness anc } \\
\text { Permanencey }\end{array}$ & & & & & \\
\hline $\begin{array}{l}\text { Reduction of } \\
\text { Toxicity, Mobility, } \\
\text { and Volume } \\
\text { Through } \\
\text { Treatment }\end{array}$ & & & & & \\
\hline $\begin{array}{l}\text { Short-Term } \\
\text { Effectiveness }\end{array}$ & & & & & \\
\hline Implementability & NA & & & & \\
\hline Cost & & & & & \\
\hline
\end{tabular}


Table ES.3. Summary of Estimated Costs

\begin{tabular}{|c|c|c|c|c|}
\hline Alternative & $\begin{array}{c}\text { Capital } \\
\text { Cost }\end{array}$ & $\begin{array}{l}\text { Present Worth of } \\
\text { Annual } \\
\text { Operations and } \\
\text { Maintenance Cost }{ }^{(a)}\end{array}$ & $\begin{array}{l}\text { Present Worth } \\
\text { of Annual } \\
\text { Monitoring } \\
\text { Cost }^{(a)}\end{array}$ & $\begin{array}{l}\text { Total } \\
\text { Present } \\
\text { Worth } \\
\text { Cost }^{(\bullet)}\end{array}$ \\
\hline NO ACTION & $\$ 0$ & $\$ 0$ & $\$ 98,000$ & $\$ 98,000$ \\
\hline $\begin{array}{l}\text { LIMITED } \\
\text { ACTION }\end{array}$ & $\$ 11,000$ & $\$ 31,000$ & $\$ 98,000$ & $\$ 140,000$ \\
\hline $\begin{array}{l}\text { IN SITU } \\
\text { CAPPING }\end{array}$ & $\$ 182,000$ & $\$ 33,000$ & $\$ 75,000$ & $\$ 290,000$ \\
\hline $\begin{array}{l}\text { DREDGE AND } \\
\text { DISPOSE }\end{array}$ & $\$ 164,000$ & $\$ 0$ & $\$ 27,000$ & $\$ 191,000$ \\
\hline $\begin{array}{l}\text { DREDGE AND } \\
\text { TREAT }\end{array}$ & $\$ 139,000$ & $\$ 51,000$ & $\$ 27,000$ & $\$ 217,000$ \\
\hline
\end{tabular}

(a) Present worth, assuming 30 years at 5 percent.

In Situ Capping would effectively meet the RAOs over the short term by isolating the contaminants in situ, and inhibiting the mobility of the PCBs into the food chain. However, it would require continual monitoring and annual maintenance. Thus, its long-term effectiveness is uncertain and relative costs are high. In addition, it would destroy the existing stream bed and local ecosystem and raise the base level of the stream.

Both removal alternatives, Dredge and Dispose and Dredge and Treat, would effectively meet the RAOs by removing $\sim 80 \%$ of the PCB contamination from the slough. Dredging would have a short-term adverse affect on the stream bed and the local ecosystem. Only the Dredge and Treat alternative would permanently reduce the volume and toxicity of the PCBs (via biological dechlorination). 


\title{
LIST OF ACRONYMS
}

\author{
AAC Alaska Administrative Code \\ ADEC Alaska Department of Environmental Conservation \\ AFB Air Force Base \\ ARAR Applicable or relevant and appropriate requirements \\ AWOC Ambient water quality criteria \\ BTEX benzene, toluene, ethylbenzene, and xylene \\ BLRA Baseline Risk Assessment \\ C Centigrade \\ CE Civil Engineers \\ CERCLA Comprehensive Environmental Response, Compensation, and Liability Act \\ CFR Code of Federal Regulations \\ DCE Dichloroethylene \\ DDT Dichlorodiphenyltrichloroethane \\ DRO diesel range organics \\ EPA Environmental Protection Agency \\ FDA Food and Drug Administration \\ FFA Federal Facility Agreement \\ FNSB Fairbanks North Star Borough \\ FS Feasibility Study \\ IRIS Integrated Risk Information System \\ IRP Installation Restoration Program \\ KEPG potassium polyethylene glycol \\ MCL maximum contaminant level \\ NCP National Contingency Plan \\ NOAA National Oceanic and Atmospheric Administration \\ NPL National Priorities List \\ O\&M Operations and Maintenance \\ OSHA Occupational Safety and Health Administration \\ OU Operable Unit \\ OUUU Ozone, Ultraviolet, Ultrasonic Water process \\ PAH polynuclear aromatic hydrocarbons \\ PCB polychlorinated biphenyl \\ PEL permissible exposure limits \\ PNL Pacific Northwest Laboratory \\ PRG Preliminary Remediation Goal \\ RAO Remedial Action Objectives \\ RCRA Resource Conservation and Recovery Act \\ RI/FS Remedial Investigation/Feasibility Study \\ SARA Superfund Amendments and Reauthorization Act \\ SER Source Evaluation Report \\ SOC Sediment Quality Criteria \\ TBC To Be Considered \\ TCE Trichloroethylene \\ TCLP Toxicity Characteristic Leaching Procedure \\ TSCA Toxic Substances Control Act \\ USAF United States Air Force \\ VOC Volatile Organic Compound
}


-

• 


\section{CONTENTS}

Executive Summary $\ldots \ldots \ldots \ldots \ldots \ldots \ldots \ldots \ldots \ldots \ldots \ldots \ldots \ldots \ldots \ldots$

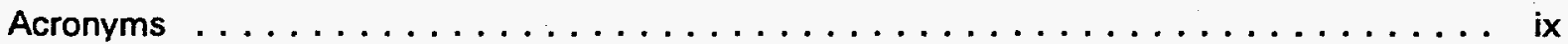

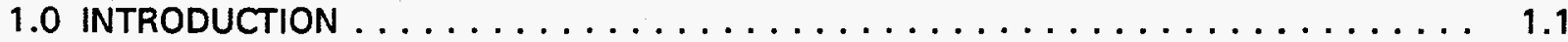

1.1 SITEWIDE BACKGROUND AND HISTORY $\ldots \ldots \ldots \ldots \ldots \ldots \ldots \ldots \ldots \ldots \ldots$

1.2 NATURE AND EXTENT OF CONTAMINATION $\ldots \ldots \ldots \ldots \ldots \ldots \ldots \ldots \ldots \ldots$

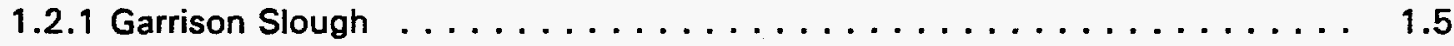

1.2 .2 French Creek . . . . . . . . . . . . . . . . . . . 1.6

1.2.3 Moose Creek and Piledriver Slough $\ldots \ldots \ldots \ldots \ldots \ldots \ldots \ldots \ldots \ldots \ldots$

1.2.4 Flightline Pond and Lily Lake . . . . . . . . . . . . . . . . . . . 1.7

1.3 SITE CHARACTERISTICS AND SPECIAL CONSIDERATIONS . . . . . . . . . . . 1.7

1.4 SCOPE OF THE SITEWIDE FEASIBILITY STUDY $\ldots \ldots \ldots \ldots \ldots \ldots \ldots \ldots \ldots$

2.0 DEVELOPMENT OF REMEDIAL ACTION OBJECTIVES $\ldots \ldots \ldots \ldots \ldots \ldots \ldots$

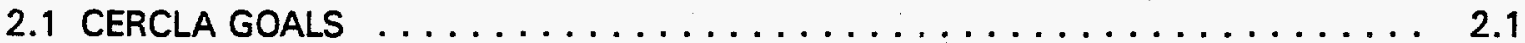

2.2 FINDINGS OF THE BASELINE RISK ASSESSMENT $\ldots \ldots \ldots \ldots \ldots \ldots \ldots \ldots .2$

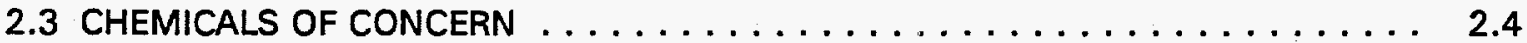

2.4 APPLICABLE OR RELEVANT AND APPROPRIATE REQUIREMENTS $\ldots \ldots \ldots \ldots .2 .5$

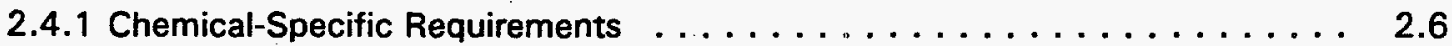

2.4.2 Location-Specific Requirements . . . . . . . . . . . . . . 2.9

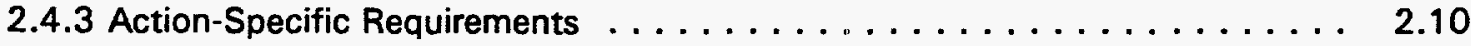

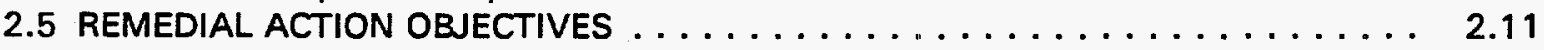

2.6 TARGET AREA FOR REMEDIAL ACTION $\ldots \ldots \ldots \ldots \ldots \ldots \ldots \ldots \ldots \ldots$

3.0 IDENTIFICATION AND SCREENING OF REMEDIAL TECHNOLOGIES $\ldots \ldots \ldots \ldots$

3.1 RESPONSE ACTIONS AND TECHNOLOGIES FOR REMEDIATING THE

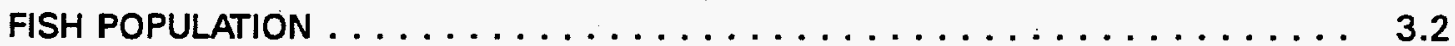

3.2 RESPONSE ACTIONS AND TECHNOLOGIES FOR REMEDIATING AQUATIC

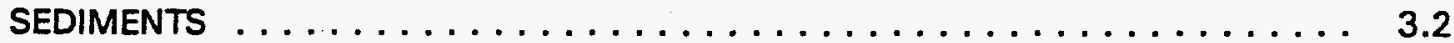

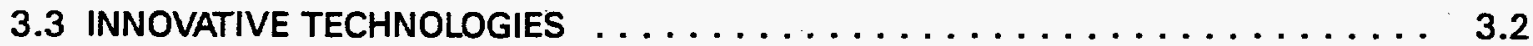

3.3.1 Algal Mats . . . . . . . . . . . . . . . . . . 3.2

3.3.2 Ozone, Ultraviolet, Ultrasonics, and Ultrapure Water . . . . . . . . . 3.3

3.3.3 In Situ Reduction . . . . . . . . . . . . . . . . . . 3.3

4.0 PRELIMINARY DEVELOPMENT AND EVALUATION OF ALTERNATIVES $\ldots \ldots \ldots \ldots$

4.1 PROCESS FOR THE DEVELOPMENT OF ALTERNATIVES $\ldots \ldots \ldots \ldots \ldots \ldots \ldots$

4.2 GENERAL REMEDIAL ACTION ALTERNATIVES $\ldots \ldots \ldots \ldots \ldots \ldots \ldots \ldots \ldots \ldots$

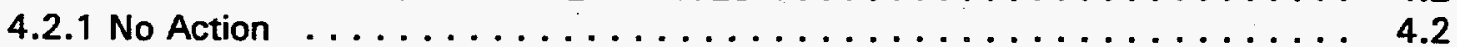

4.2 .2 Limited Action $\ldots \ldots \ldots \ldots \ldots \ldots \ldots \ldots \ldots \ldots \ldots \ldots . \ldots \ldots . . \ldots \ldots$

4.2 .3 In Situ Capping . . . . . . . . . . . . . . . . . . . . 4.6

4.2.4 Divert Stream . . . . . . . . . . . . . . . . . . . 4.6

4.2.5 Dredge and Dispose . . . . . . . . . . . . . . . . 4.7

4.2.6 Dredge and Treat $\ldots \ldots \ldots \ldots \ldots \ldots \ldots \ldots \ldots \ldots \ldots \ldots . \ldots \ldots$

4.3 EVALUATION OF ALTERNATIVES $\ldots \ldots \ldots \ldots \ldots \ldots \ldots \ldots \ldots \ldots \ldots \ldots$

5.0 DETAILED ANALYSIS OF ALTERNATIVES $\ldots \ldots \ldots \ldots \ldots \ldots \ldots \ldots \ldots \ldots$ 
5.1 DETAILED DEVELOPMENT OF ALTERNATIVES FOR GARRISON SLOUGH $\ldots \ldots$

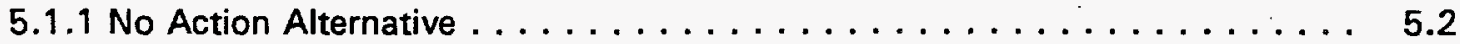

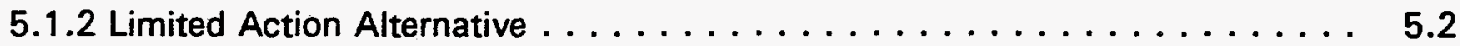

5.1 .3 In Situ Capping Alternative . . . . . . . . . . . . . . . . . 5.3

5.1 .4 Dredge and Dispose Alternative $\ldots \ldots \ldots \ldots \ldots \ldots \ldots \ldots \ldots \ldots$

5.1 .5 Dredge and Treat Alternative . . . . . . . . . . . . . . . . 5.8

5.1 .6 Summary of the Alternatives for Garrison Slough . . . . . . . . . . . 5.10

5.2 INDIVIDUAL EVALUATION OF ALTERNATIVES $\ldots \ldots \ldots \ldots \ldots \ldots \ldots \ldots \ldots \ldots$

5.3 COMPARATIVE EVALUATION OF ALTERNATIVES $\ldots \ldots \ldots \ldots \ldots \ldots \ldots \ldots \ldots$

6.0 REFERENCES $\ldots \ldots \ldots \ldots \ldots \ldots \ldots \ldots \ldots \ldots \ldots \ldots \ldots \ldots \ldots \ldots \ldots$

APPENDIX A - ASSUMPTIONS AND CALCULATIONS USED IN THE DEVELOPMENT AND EVALUATION OF ALTERNATIVES $\ldots \ldots \ldots \ldots \ldots \ldots \ldots \ldots \ldots$

APPENDIX B - REMEDIAL ACTION ALTERNATIVE COST ESTIMATES $\ldots \ldots \ldots \ldots$. . . . B.3 


\section{FIGURES}

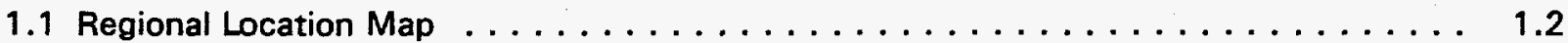

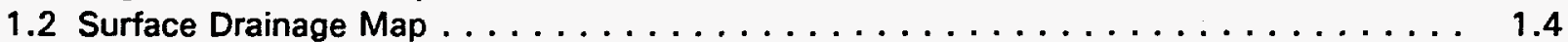

1.3 Surface Water and Sediment Sampling Locations (1994). . . . . . . . . . . . . . . . 1.8

2.1 Relationship Between Sediment and Fish Concentrations in Garrison Slough,

Based on 1994 Sediment and Fish Tissue Sampling $\ldots \ldots \ldots \ldots \ldots \ldots \ldots \ldots$

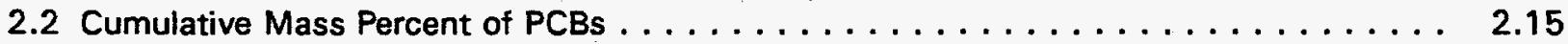

3.1 Initial Screening of Technologies and Process Options for Remediation of Fish . . . . . 3.5

3.2 Evaluation of Process Options for Remediation of the Fish Population . . . . . . . . 3.7

3.3 Initial Screening of Technologies and Process Options for Remediation of

Aquatic Sediments . . . . . . . . . . . . . . . . . . . . . 3.10

3.4 Evaluation of Process Options for Remediation of Aquatic Sediments . . . . . . . . 3.20

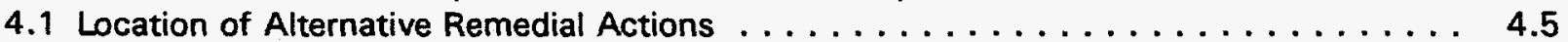

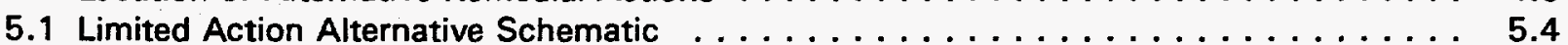

5.2 In Situ Capping Alternative Schematic . . . . . . . . . . . . . . . . . . . . . 5.5

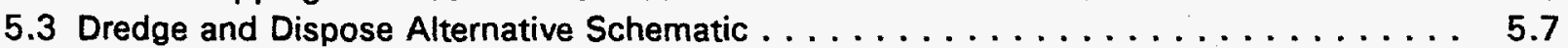

5.4 Land Farming Alternative Schematic $\ldots \ldots \ldots \ldots \ldots \ldots \ldots$ 


\section{TABLES}

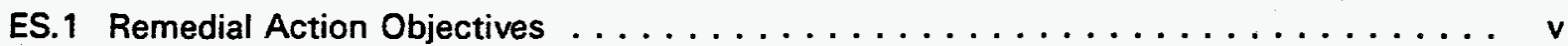

ES.2 Comparison of Remedial Action Alternatives Using the Five Balancing Criteria . . . . . vii

ES.3 Summary of Estimated Costs . . . . . . . . . . . . . . . . . viii

2.1 Summary of Baseline Risk Assessment Results (USAF 1995b) . . . . . . . . . 2.3

2.2 Cancer Risk and Hazard Index at Lower Garrison Slough (USAF 1995b) . . . . . . . 2.4

2.3 Chemicals of Concern for Garrison Slough . . . . . . . . . . . . . . . . . 2.5

2.4 EPA Ambient Water Quality Criteria for Contaminants Identified in Surface Water at Eielson AFB . . . . . . . . . . . . . . . . . .

2.5 Alaska Water Quality Criteria $\ldots \ldots \ldots \ldots \ldots \ldots \ldots \ldots \ldots \ldots \ldots \ldots \ldots \ldots \ldots$

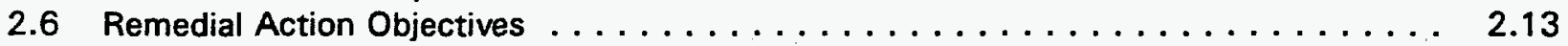

3.1 Response Actions and Technologies for Remediation of the Fish Population . . . . . 3.4

3.2 Response Actions and Technologies for Remediation of Aquatic Sediments . . . . . 3.8

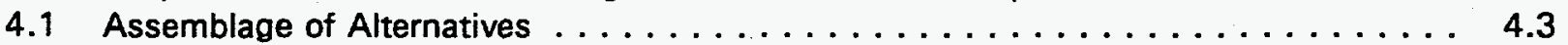

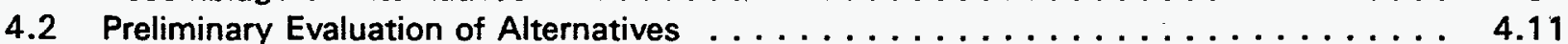

5.1 NCP Criteria for Evaluating Alternatives $\ldots \ldots \ldots \ldots \ldots \ldots \ldots \ldots \ldots \ldots \ldots \ldots$

5.2. Primary Components in Alternatives for Garrison Slough . . . . . . . . . . . . . 5.10

5.3 Individual Analysis of the Garrison Slough No Action Alternative . . . . . . . . . 5.12

5.4 Individual Analysis of the Garrison Slough Limited Action Alternative . . . . . . . . . 5.13

5.5 Individual Analysis of the Garrison Slough In Situ Capping Alternative . . . . . . . 5.15

5.6 Individual Analysis of the Garrison Slough Dredge and Dispose Alternative . . . . . 5.18

5.7 Individual Analysis of the Garrison Slough Dredge and Treat Alternative . . . . . . 5.21

5.8 Comparative Analysis of the Garrison Slough Alternatives $\ldots \ldots \ldots \ldots \ldots \ldots .24$ 


\subsection{INTRODUCTION}

The Sitewide Feasibility Study (FS) is required under the Comprehensive Environmental Response, Compensation, and Liability Act (CERCLA), the National Contingency Plan (NCP), and the Federal Facility Agreement (FFA) for Eielson Air Force Base (AFB).

The remedial investigation/feasibility study (RI/FS) process provides an opportunity for early selection of final remedies for specific source areas. The sitewide RI/FS is a streamlined set of documents prepared in response to the request from the U.S. Air Force (USAF), U.S. Environmental Protection Agency (EPA), and Alaska Department of Environmental Conservation (ADEC) Remedial Project Managers for a narrowly focused evaluation of contamination that is not confined or attributed to a specific operable unit or other source area evaluation group.

The sitewide FS is based on the findings presented in the following documents:

- Surface Water and Sediment Investigation Draft Report (USAF 1994d)

- Screening Baseline Risk Assessment (USAF 1994a)

- Biological Risk Assessment (USAF 1995d)

- Technical Memo: "Preliminary Assessment of PCB Sediment Contamination in Garrison Slough" (a)

- Sitewide Remedial Investigation (RI) Report (USAF 1995a)

- Sitewide Baseline Risk Assessment (BLRA) Report (USAF 1995b)

\subsection{SITEWIDE BACKGROUND AND HISTORY}

Eielson AFB encompasses approximately 8000 hectares $(19,770$ acres $)$ in interior Alaska, $160 \mathrm{~km}$ $(99$ mi) south of the Arctic Circle (Figure 1.1). In carrying out its defense mission, contamination of the soils and groundwater at the base has resulted from the storage and handling of fuels, oils, and solvents, plus the operation of landfills. Initially this contamination was evaluated under the U.S. Air Force Installation Restoration Program (IRP). In 1982, the IRP was initiated with a record search to identify past disposal sites containing contaminants that may pose a hazard to human health or the environment.

Under the IRP, the U.S. Air Force identified 64 potential areas of contamination at Eielson AFB. These potential source areas include old landfills, storage and disposal areas, fueling system leaks, and spill areas.

(a) Technical Memo. "Preliminary Assessment of PCB Sediment Contamination in Garrison Slough, Eielson Air Force Base, Alaska." Prepared by the Pacific Northwest Laboratory, Richland, Washington, for the U.S. Air Force Environmental Restoration Program, Eielson Air Force Base, Alaska. Pacific Northwest Laboratory is operated by Battelle Memorial Institute for the U.S. Department of Energy under Contract DE-AC06-76RLO 1830. 


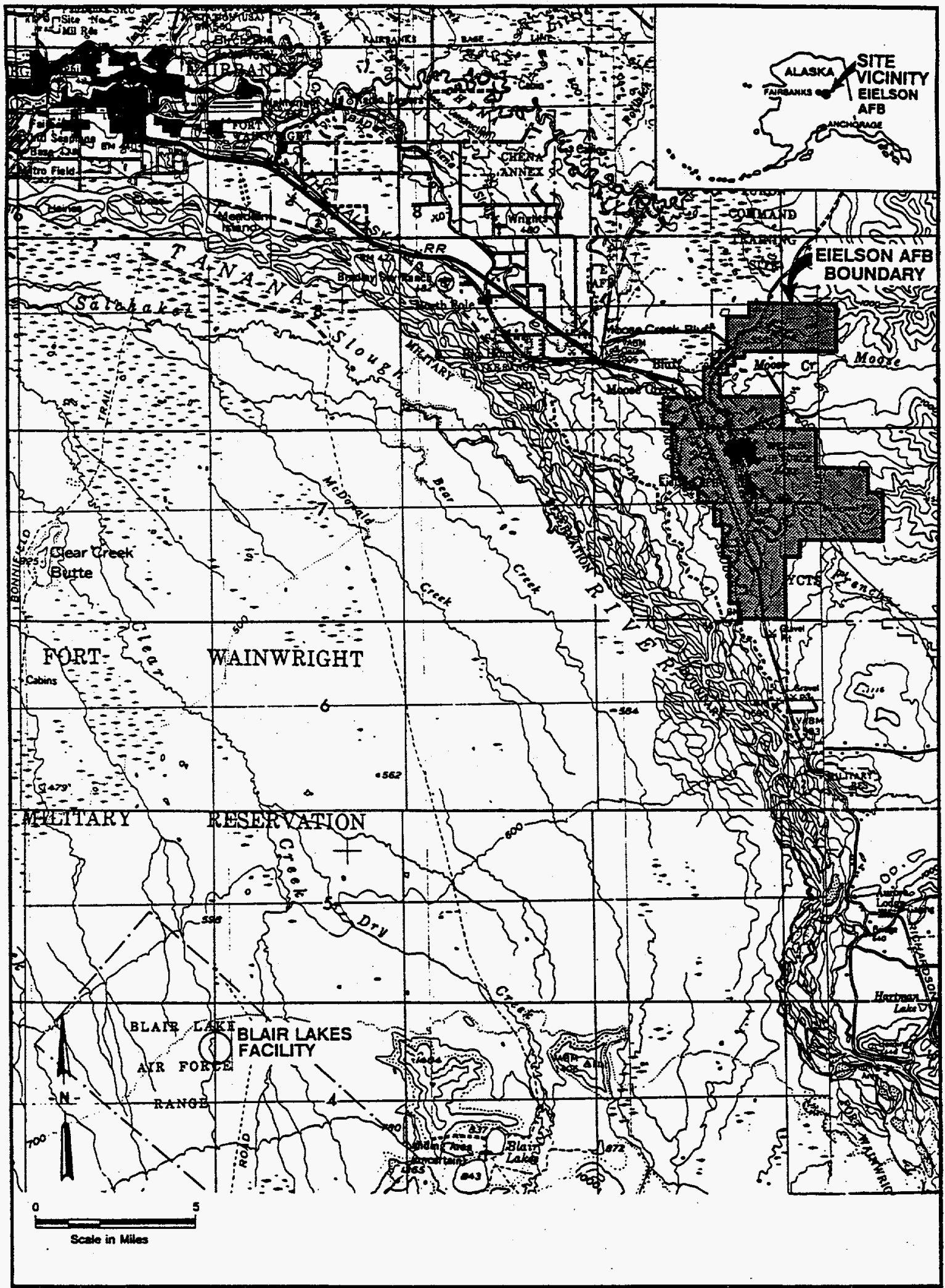

Figure 1.1. Regional Location Map 
Eielson AFB was listed on the National Priorities List (NPL) (54 Fed. Reg. 48184) on November 21, 1989 by the EPA. This listing designated the facility as a federal Superfund site subject to the remedial response requirements of CERCLA, as amended by the Superfund Amendments and Reauthorization Act (SARA).

In May 1991, the U.S. Air Force, the State of Alaska, and the EPA entered into an FFA (EPA et al. 1991) that established the procedural framework and schedulle for developing, implementing, and monitoring CERCLA response actions. Under the FFA, the 64 potential source areas were placed in one of six operable units (OUs), based on similar contaminant and environmental characteristics, or were included for evaluation under a Source Evaluation Report (SER).

The sitewide remedial investigation (RI) of Eielson AFB investigated contamination that was not confined to an OU or SER source area. Sitewide issues will be addressed in a Sitewide Record of Decision. The objectives of the sitewide RI were to:

- provide information about site characteristics to support individual OU RI/FS efforts and the sitewide RI/FS, including site hydrogeology and determination of background soil and groundwater characteristics;

- identify and characterize contamination that is not confined or attributable to a specific source area through sitewide monitoring of groundwater and surface water;

- evaluate cumulative risks to human health and the environment from contamination on a sitewide basis; and

- provide a mechanism for continued cohesive sitewide monitoring.

The main base is located in the Tanana River Valley, about $5 \mathrm{~km}(3 \mathrm{mi})$ east of the river. Tributaries flowing through Eielson AFB include: Piledriver Slough to the west, Moose Creek to the east, French Creek to the northeast and Garrison Slough, which flows through the developed portion of the base (Figure 1.2).

To ensure that offsite communities are not negatively affected by site contamination, several surface water bodies and the North Boundary wells have been monitored for contamination. The North Boundary Wells are sampled annually to monitor groundwater quality downgradient of the developed portion of the base. The surface water bodies included in this assessment are:

- Garrison Slough

- French Creek

- Moose Creek

- Piledriver Slough

- Flightline Pond

- Lily Lake 


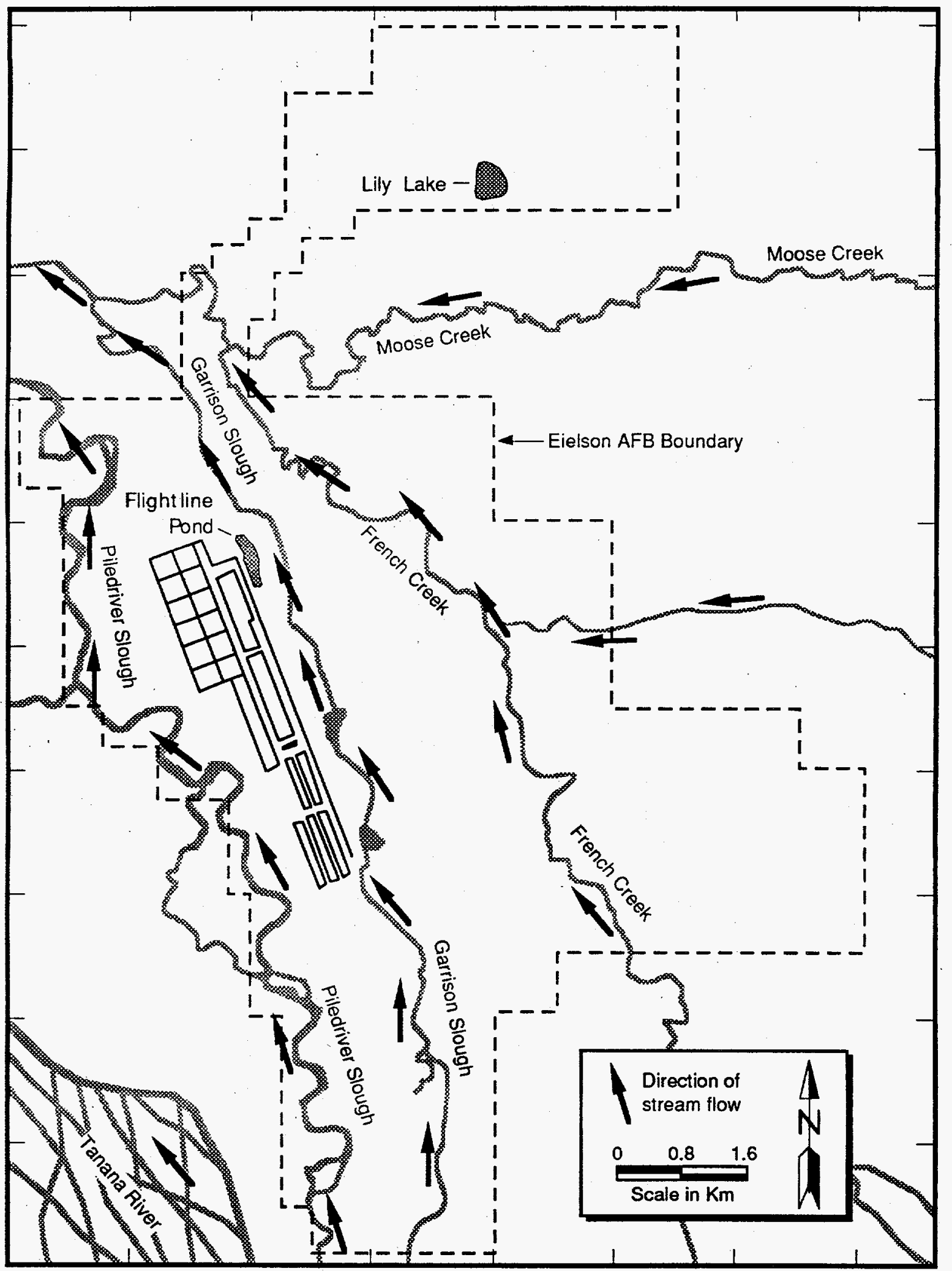

Figure 1.2. Surface Drainage Map 


\subsection{NATURE AND EXTENT OF CONTAMINATION}

The sitewide RI investigated contamination in groundwater, surface water, sediment, and aquatic biota. Contamination in excess of natural background levels was not identified in groundwater at the downgradiant (north) edge of the base (USAF 1992; USAF 1994c; USAF 1995c).

Surface water bodies at or in the vicinity of Eielson AFB cross OU boundaries and may have been affected by contaminants from past base activities. Garrison Slough is the most likely surface water body to have been affected by contamination because it is near 16 potential contaminant source areas, and because it receives most of the surface runoff from the developed portion of the base. Garrison Slough may also receive contaminated ground water from several source areas.

Consequently, past investigations of surface water and sediment quality have focused on Garrison Slough. Few water samples were collected from French Creek, Piledriver Slough, or other surface water bodies during the 1988 through 1990 IRP investigations. Surface water and sediment at selected locations have been sampled by the U.S. Air Force's Bioenvironmental Engineering Services at Eielson AFB since April, 1992. Additional information about the surface water and sediment quality was collected in 1993 (USAF 1994d) and 1994(b) (USAF 1995a) to assess the risk to human health and the environment. That investigation was performed in conjunction with the biological risk assessment (USAF 1994e), and included Garrison Slough, French Creek, Moose Creek, Piledriver Slough, Flightline Pond, and Lily Lake (USAF 1994d).

Results from these investigations indicate that Garrison Slough has been the most affected by base activities. The other surface water bodies show only traces of contamination. Concentrations of metals in water and sediment samples were within the ranges of background values for groundwater and soil at Eielson AFB. A brief description of the nature and extent of contamination found in surface water bodies at or in the vicinity of Eielson AFB is presented in following paragraphs.

\subsubsection{Garrison Slough}

Garrison Slough shows the greatest impact from base activities. Fuel-related volatile organics, chlorinated solvents, and pesticides were detected in surface water. Pesticides, diesel range organics (DRO), and polychlorinated biphenyls (PCBs) were detected in sediments. Concentrations of metals in water and sediment were generally within the ranges of background values for groundwater and soil on the base (USAF 1994d).

Fuel-Related Compounds. Fuel-related compounds (benzene and ethylbenzene) were detected at low concentrations (less than or equal to $2.6 \mu \mathrm{g} / \mathrm{L}$ ) in surface water samples from the entire length of Garrison Slough. The most likely source of these compounds is contaminated groundwater discharging to the slough from one or more adjacent source areas (e.g., LF03/FT09, ST48) (USAF 1994a).

(a) Technical Memo. "Preliminary Assessment of PCB Sediment Contamination in Garrison Slough, Eielson Air Force Base, Alaska." Prepared by the Pacific Northwest Laboratory, Richland, Washington for the U.S. Air Force Environmental Restoration Program, Eielson Air Force Base, Alaska. 
Chlorinated Solvents. Trichloroethylene (TCE) was detected in all water samples from Garrison Slough, except at sampling station GSOO (Figure 1.3). The maximum concentration (0.8 $\mu \mathrm{g} / \mathrm{L}$ ) was detected at station GS06, near the fire training area, in 1992. Cis-1,2-DCE was detected at all stations except GSO4 and GSO6, with the maximum concentration $(2.2 \mu \mathrm{g} / \mathrm{L})$ detected at GSO5. Possible sources of these compounds are contaminated groundwater discharging to the slough from source areas LFO3, ST18, and ST48.

Diesel Range Organics. DROs were detected in sediment samples with concentrations ranging from $14 \mathrm{mg} / \mathrm{kg}$ to $38 \mathrm{mg} / \mathrm{kg}$ at four of seven sampling stations. Potential sources for DRO include surface runoff from roads, the runway, and adjacent source areas.

Pesticides. Low concentrations of pesticides (4,4'-DDD, 4,4'-DDE, and delta-BHC) were detected in surface water from Garrison Slough at a maximum concentration of $0.052 \mu \mathrm{g} / \mathrm{L}$. The pesticides 4,4'-DDT, 4,4'-DDD, 4,4'-DDE, endosulfan sulfate, and delta-BHC were detected in sediment samples at a maximum concentration of $170 \mu \mathrm{g} / \mathrm{kg}$. Fish tissue samples also contained detectable concentrations of pesticides, including DDT isomers, its metabolites, hexachlorobenzene, and dieldrin. The pesticides were probably introduced by the routine application of pesticides at the base.

Polychlorinated Biphenyls. PCBs with a maximum concentration of $7650 \mu \mathrm{g} / \mathrm{kg}$ were detected in 6 of 11 sediment samples collected near Arctic Avenue in 1990 (HLA 1991). Sediment samples collected in 1994 confirmed the presence of PCBs, with a maximum concentration of $55,000 \mu \mathrm{g} / \mathrm{kg}$ measured at sampling station GS12 near Building 2350 (Figure 1.3)(a). PCBs were not detected upstream of station GS12. Approximately $240 \mathrm{~m}$ ( 260 yd) downstream, the PCB concentration dropped by an order of magnitude to $3200 \mu \mathrm{g} / \mathrm{kg}$ (at GS07). At GS09, approximately $470 \mathrm{~m}$ (503 yd) further downstream, the PCB concentration dropped another order of magnitude to $130 \mu \mathrm{g} / \mathrm{kg}$. The PCB concentration was on the same order of magnitude $(230 \mu \mathrm{g} / \mathrm{kg})$ at Transmitter Road (GSO6). This PCB contamination appears to originate (perhaps from surface runoff or an incidental spill) from a point source just south of Building 2350, which houses a vehicle maintenance shop. Aroclor 1260 was above detection limits in fish tissue samples collected from throughout Garrison Slough, with the highest concentrations ( $3000 \mu \mathrm{g} / \mathrm{kg}$ wet weight) collected from lower Garrison Slough. Aroclor 1260 was also detected in invertebrates collected from lower Garrison Slough.

\subsubsection{French Creek}

Surface water samples from French Creek showed traces of pesticides (4,4'-DDD, 4,4'-DDE, and dieldrin). Methylene chloride was detected at a concentration of less than $1 \mu \mathrm{g} / \mathrm{L}$ in one sample; its presence is probably due to laboratory contamination. DRO were detected at a concentration of $11 \mathrm{mg} / \mathrm{kg}$ in the sediment sample collected adjacent to source area LFO2.

One of four fish tissue samples collected from French Creek near Quarry Road, and two of four samples from lower French Creek contained detectable levels of PCB (Aroclor 1260). The respective maximum concentrations were 28.9 and $24.6 \mu \mathrm{g} / \mathrm{kg}$ wet weight. Aroclor 1260 was the

(a) Technical Memo. "Preliminary Assessment of PCB Sediment Contamination in Garrison Slough, Eielson Air Force Base, Alaska". Prepared by the Pacific Northwest Laboratory, Richland, Washington, for the U.S. Air Force Environmental Restoration Program, Eielson Air Force Base, Alaska. 
principal contributor to the total cancer risk for the locations 4E-05 and 5E-05 (USAF 1995b). DDT isomers and its metabolites were also detected in fish tissue samples from French Creek.

\subsubsection{Moose Creek and Piledriver Slough}

Moose Creek and Piledriver Slough appear to be almost free of contamination. No contaminants were detected in surface water from Moose Creek (collected downstream of its confluence with French Creek). Only a trace of tetrachloroethylene $(0.071 \mu \mathrm{g} / \mathrm{L})$ was detected in surface water from Piledriver Slough (sampling station PS01). The tetrachloroethylene may have derived from source area LF01, although it was not detected in groundwater collected from a monitoring well located between LFO1 and the slough.

DRO and diethylphthalate were detected in the Moose Creek sediment sample at concentrations of $12 \mathrm{mg} / \mathrm{kg}$ and $460 \mu \mathrm{g} / \mathrm{kg}$, respectively. The source of DRO may be upstream sediment or the adjacent roadway. The diethylphthalate is probably a laboratory contaminant; phthalate esters are used as plasticizers and are common laboratory contaminants.

One of four fish tissue samples collected from Piledriver Slough contained detectable levels of PCBs (Aroclor 1260 ); $17.6 \mu \mathrm{g} / \mathrm{kg}$ wet weight. This sample was the principal contributor to the total cancer risk of 3E-05 (USAF 1995b). The source of PCBs in the one fish tissue sample from Piledriver Slough has not been identified.

DDT isomers, its metabolites, and hexachlorobenzene were also detected in fish tissue samples from Piledriver Slough, as well as from upper Moose Creek (excluding hexachlorobenzene).

\subsubsection{Flightline Pond and Lily Lake}

The only contaminant detected in the water sample from Flightline Pond was a trace of the pesticide delta-BHC. The sediment from Flightline Pond contained DRO at a concentration of $41 \mathrm{mg} / \mathrm{kg}$ and 10 PAHs at a maximum concentration of $2600 \mu \mathrm{g} / \mathrm{kg}$ (pyrene). The hydrocarbons probably originated from jet exhaust from the runway south of the pond. No contaminants were detected in the water sample from Lily Lake (USAF 1995a). The sediment sample contained $11 \mathrm{mg} / \mathrm{kg}$ DRO and 5 PAHs at a maximum concentration of $1400 \mu \mathrm{g} / \mathrm{kg}$ (pyrene) (USAF 1995a).

\subsection{SITE CHARACTERISTICS AND SPECIAL CONSIDERATIONS}

Eielson AFB is located within the Fairbanks North Star Borough (FNSB) approximately $40 \mathrm{~km}$ (25 mi) southeast of Fairbanks and $26 \mathrm{~km}(16 \mathrm{mi})$ southeast of the city of North Pole, Alaska, along the Richardson Highway (Figure 1.1). Approximately 1477 hectares (3650 acres) of the base are improved or partially improved with the remaining land encompassing forest, wetlands, lakes, and ponds. The base is bounded on the east and south by Fort Wainwright, a U.S. Army installation, and on the west and north by private and public land. The base is isolated from major urban areas with the adjacent public and private land zoned for general use. The approximate population of the FNSB, Fairbanks, and North Pole is $82,000,32,000$, and 1600 , respectively. Other communities near Eielson AFB include Moose Creek, which abuts the northern border of the base, and the Salcha area, which abuts the southern border of the base. 


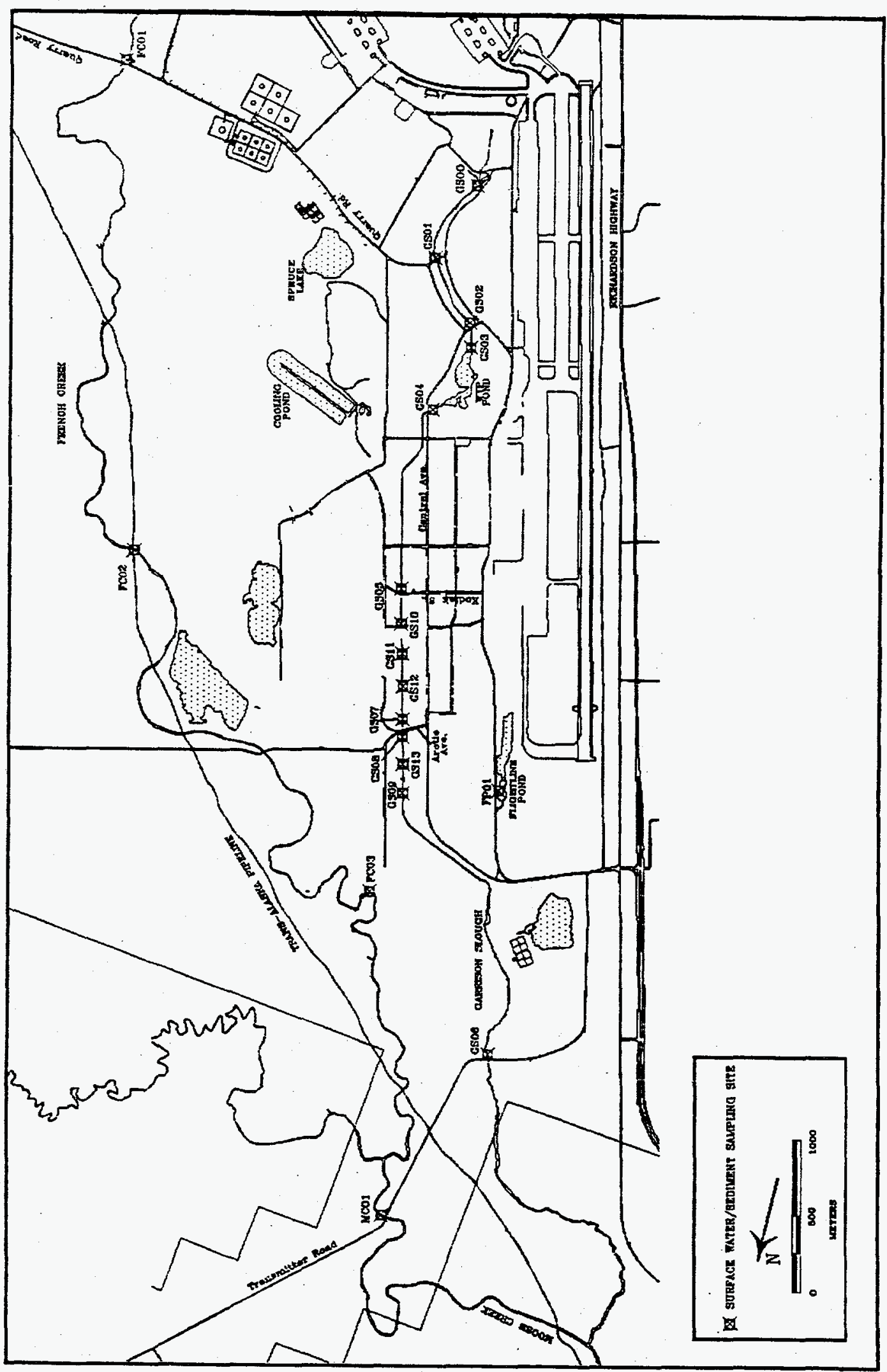

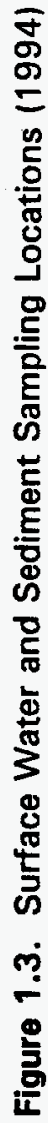


The main base is located in the Tanana River Valley, about $5 \mathrm{~km}$ ( $3 \mathrm{mi}$ ) east of the river. Regional drainage is northwestward into the Tanana River, which flows into the Yukon River. Tributaries flowing through Eielson AFB include: Piledriver Slough to the west, Moose Creek to the east, and French Creek to the northeast. Garrison Slough flows from the south to north through the developed portion of the base (Figure 1.3).

The climate is characterized by large diurnal and seasonal temperature variations, low precipitation, and low humidity. Average summer temperatures range between 7 and $16^{\circ}$ Centigrade (C) (44.6 and $60.8^{\circ} \mathrm{F}$.

Average winter temperatures range between -26 and $-13^{\circ} \mathrm{C}\left(-14.8\right.$ and $\left.-8.6^{\circ} \mathrm{F}\right)$. The extreme temperatures recorded since 1944 are a high of $33^{\circ} \mathrm{C}\left(91.4^{\circ} \mathrm{F}\right)$ in June and $-53^{\circ} \mathrm{C}\left(-63.4^{\circ} \mathrm{F}\right)$ in January. The average annual precipitation is $36 \mathrm{~cm}(14.2 \mathrm{in}$.$) , which includes 180 \mathrm{~cm}(70.9 \mathrm{in}$.) of snow. Average monthly precipitation ranges from $1.3 \mathrm{~cm}(0.5 \mathrm{in}$.$) to 6.4 \mathrm{~cm}(2.5 \mathrm{in}$.$) . The$ greatest rainfall usually occurs in July and August.

The developed portion of the base, which has been constructed on fill material, is underlain by a shallow, unconfined aquifer comprised of 60 to $90 \mathrm{~m}$ (65.6 to $98.4 \mathrm{yd}$ ) of loose alluvial sands and gravel overlying relatively low-permeability bedrock. The aquifer is characterized by high transmissivities and relatively flat groundwater gradients. Depth to the top of the unconfined aquifer ranges between 1.5 and $4.5 \mathrm{~m}$ (1.6 to $4.9 \mathrm{yd})$. The groundwater generally flows to the northnorthwest with the direction of flow locally influenced by Garrison Slough and groundwater extraction from the base supply wells. Garrison Slough is believed to be lower than the water table throughout the year over most of the slough's length, acting as a drain for the shallow aquifer (PNL 1993bl.

Groundwater is the only source of potable water at the base and in the nearby communities. The water contains high background concentrations of metals, including arsenic $(<5$ to $10 \mu \mathrm{g} / \mathrm{l})$, iron $(<20$ to $9,000 \mu \mathrm{g} / \mathrm{l})$, magnesium $(4,000$ to $20,000 \mu \mathrm{g} / \mathrm{l})$, and manganese $(<10$ to $4,000 \mu \mathrm{g} / \mathrm{l})$ (USAF 1992). Potable water in the main base water distribution system is treated to remove iron and sulfide. Groundwater is also the principal water source for various other industrial, domestic, agricultural, and firefighting uses.

Eielson AFB facilities are actively used by the Alaskan Air Command in support of the strategic defense mission of the USAF. Site contamination is largely the result of past fuel spills and leaks from fuel loading, unloading, storage, and distribution activities. These fuel handling activities remain vital to the ongoing mission of the base and will actively continue as part of future base operations. Remediation in active areas will be coordinated, to the extent feasible, with ongoing base activities, including maintenance and construction.

It is also extremely important that fuel handling activities do not continue to serve as a source of release to the environment. Any active leaks need to be identified and corrected before beginning remediation of contaminated soils, floating fuel, or groundwater. For the purpose of preparation of the sitewide FS, it has been assumed that active fuel handling and storage activities will be conducted in accordance with applicable requirements.

\subsection{SCOPE OF THE SITEWIDE FEASIBILITY STUDY}

The sitewide FS is a streamlined feasibility study that focuses on the evaluation of technologies that provide the most viable alternatives for remediation of aquatic sediments and fish populations in 
lower Garrison Slough. The alternatives proposed in this FS are designed to address PCB contaminated sediments and fish populations as described in Section 1.2.

All other areas addressed by the sitewide remedial investigation have been determined to present an acceptable risk to human health and the environment (USAF 1995b). 


\subsection{DEVELOPMENT OF REMEDIAL ACTION OBJECTIVES}

This section presents the development of RAOs for the contaminated portions of Garrison Slough. The RAOs have been developed using the general remediation goals defined by CERCLA, the findings presented in the Surface Water and Sediment Investigation Draft Report (USAF 1994d), the Preliminary Assessment of PCB Sediment Contamination in Garrison Slough ${ }^{\text {(a) }}$, the Sitewide RI Report (USAF 1995a), the Screening Baseline Risk Assessment (USAF 1994a), the Biological Risk Assessment (USAF 1995d), the Baseline Risk Assessment (USAF 1995b), and applicable or relevant and appropriate regulatory requirements (ARARs).

\subsection{CERCLA GOALS}

General remediation goals for cleanup of releases of hazardous substances have been defined by CERCLA and are implemented through the requirements of the NCP. The NCP establishes an evaluation process for selection of remedies that are protective of human health and the environment, that maintain protection over time, and that minimize untreated waste. Remedial actions, where hazardous substances remain on site, must also attain the requirements promulgated under federal or state statutes that are applicable or relevant and appropriate. The ARARs may apply to remediation of a specific media (soils, surface water, or groundwater) or may apply to a specific action. CERCLA Section 121 (d) states that a remedial action will attain the standard of control established under the Safe Drinking Water Act. EPA has included the expectation that contaminated groundwaters will be returned to their beneficial uses wherever practicable, within a time frame that is reasonable for the circumstances of the site. If groundwater can be used for drinking water, CERCLA remedies should, where practicable, restore the groundwater to attain drinking water standards.

The objectives for the remedial action are developed early in the remedy selection process. The RAOs specify the contaminants and media of concern, the potential exposure pathways, and the preliminary remediation goals. The preliminary remediation goals (PRGs) identify acceptable exposure levels that will be protective of human health and the environment. The goals are developed through consideration of potential health and environmental risk and the identified ARARs.

The purpose of the remedy selection process is to implement remedies that eliminate, reduce, or control risks to human health and the environment [40 CFR 300.430(a)(1)]. The NCP identifies the following as acceptable risk to human populations:

- For noncarcinogens, an acceptable exposure is one to which human populations, including sensitive subgroups such as children and pregnant women, may be exposed without adverse effects during a lifetime or a part of a lifetime, incorporating an adequate margin of safety.

(a) Technical Memo. "Preliminary Assessment of PCB Contamination in Garrison Slough, Eielson Air Force Base, Alaska." Prepared for the U.S. Air Force Environmental Restoration Program, by the Pacific Northwest Laboratory, Richland, Washington. 
- For carcinogens, EPA has set a remedial goal for total risk that represents an excess upper bound lifetime cancer risk to an individual of between $10^{-4}$ and $10^{-6}$.

\subsection{FINDINGS OF THE BASELINE RISK ASSESSMENT}

The Sitewide Screening Baseline Risk Assessment (USAF 1994a) and the Sitewide Baseline Risk Assessment (USAF 1995b) provide an evaluation of the potential current and future risks from contaminants in surface water bodies at or in the vicinity of Eielson AFB.

Risk estimates were calculated using a recreational land-use scenario that was developed for the OU 3, 4, and 5 BLRA (USAF 1994b). This conservative scenario considers a sensitive subgroup (children) wading, playing, and fishing in surface water bodies and along their banks. Assuming these recreational activities for the land use, the following exposure pathways were considered:

- Ingestion of surface water

- Dermal contact with surface water

- Incidental ingestion of sediments

- Dermal contact with sediments

- Ingestion of fish.

Recreational land-use has been divided into two exposure scenarios - current and future. The current recreational child is assumed to be on-base for three years, which is consistent with movement of dependents. The future recreational child is assumed to play on-base for 12 years.

The recreational scenario provides for 60 days per year of exposure at surface water bodies. This assumes that a child spends 30 days fishing and 30 days playing in sediments. The figure of 30 days per year is used to represent children spending about 20 percent of their available summertime days at the slough. On the days spent fishing, fish are caught, taken home, and eaten by the child ( 300 grams per day). While at the surface water body, the child drinks $0.5 \mathrm{~L}$ of the surface water per day. It was assumed that children will be exposed to surface water sediments on their hands, arms, feet, and lower legs, representing surface areas averaging $2756 \mathrm{~m}^{2}$ for 6-year-old children and $4800 \mathrm{~m}^{2}$ for 12-year-old children.

The excess cancer risk and the Hazard Index for each surface water body are presented in Table 2.1. This table presents the values for both the current and future recreational land-use exposure scenarios. In addition, this table indicates the percentage of the risk due to the PCB concentrations in fish tissue. This table indicates that the highest excess cancer risk and hazard index values are associated with Garrison Slough, primarily lower Garrison Slough. A large percentage of these risk values (on the order of 80 to $90 \%$ ) is due to the concentration of PCBs in fish tissue samples. Table 2.2 summarizes the cancer risk and hazard index for lower Garrison Slough and indicates the primary exposure pathway is through the ingestion of fish.

Thus, the sitewide FS is focused towards remediating the source of PCBs found in lower Garrison Slough (USAF 1995a), and towards reducing/removing the primary exposure pathway (ingestion of fish). 
Table 2.1. Summary of Baseline Risk Assessment Results (USAF 1995b)

\begin{tabular}{|c|c|c|c|c|c|c|}
\hline \multirow[b]{2}{*}{ Site } & \multicolumn{2}{|c|}{$\begin{array}{c}\text { Current Recreational } \\
\text { Land Use }\end{array}$} & \multicolumn{2}{|c|}{$\begin{array}{c}\text { Future Recreational } \\
\text { Land Use }\end{array}$} & \multicolumn{2}{|c|}{ PCB Contribution } \\
\hline & $\begin{array}{l}\text { Total } \\
\text { Hazard } \\
\text { Index }\end{array}$ & $\begin{array}{c}\text { Total } \\
\text { Cancer } \\
\text { Risk }\end{array}$ & $\begin{array}{l}\text { Total } \\
\text { Hazard } \\
\text { Index }\end{array}$ & $\begin{array}{c}\text { Total } \\
\text { Cancer } \\
\text { Risk }\end{array}$ & Cancer & $\begin{array}{l}\text { Hazard } \\
\text { Index }\end{array}$ \\
\hline \multicolumn{7}{|c|}{ Background } \\
\hline Chatanika River & $<1 \mathrm{E}-07$ & $<1 \mathrm{E}-02$ & $<1 E-07$ & $<1 E-02$ & $0 \%$ & $0 \%$ \\
\hline Upper French Creek & $1 \mathrm{E}-06$ & $2 \mathrm{E}-02$ & $3 E-06$ & $1 \mathrm{E}-02$ & $0 \%$ & $0 \%$ \\
\hline \multicolumn{7}{|c|}{ Offsite Monitoring } \\
\hline Piledriver Slough & $9 E-06$ & $1 E+00$ & $3 E-05$ & 90E-01 & $85 \%$ & $99 \%$ \\
\hline Grayling Lake & $2 E-07$ & $<1 \mathrm{E}-02$ & $6 \mathrm{E}-07$ & $<1 E-02$ & $0 \%$ & $0 \%$ \\
\hline Hidden Lake & $3 E-07$ & $<1 \mathrm{E}-02$ & $1 \mathrm{E}-06$ & $<1 \mathrm{E}-02$ & $0 \%$ & $0 \%$ \\
\hline 28 Mile Pit & $<1 \mathrm{E}-07$ & $<1 \mathrm{E}-02$ & $2 \mathrm{E}-07$ & $<1 E-02$ & $0 \%$ & $0 \%$ \\
\hline \multicolumn{7}{|c|}{ Garrison Slough } \\
\hline Upper & $6 \mathrm{E}-05$ & $7 E+00$ & $2 E-04$ & $6 E+00$ & $81 \%$ & $98 \%$ \\
\hline Middle & $5 E-05$ & $3 E+00$ & $2 E-04$ & $2 E+00$ & $31 \%$ & $90 \%$ \\
\hline Lower & $1 E-03$ & $2 E+02$ & $4 E-03$ & $2 E+02$ & $98 \%$ & $100 \%$ \\
\hline Transmitter Road & $4 \mathrm{E}-07$ & $1 E-02$ & $3 E-07$ & $1 E-02$ & $0 \%$ & $0 \%$ \\
\hline $\begin{array}{l}\text { Moose Creek } \\
\text { Confluence }\end{array}$ & $9 E-05$ & $1 E+01$ & $3 E-04$ & $1 E+01$ & $94 \%$ & $99 \%$ \\
\hline \multicolumn{7}{|c|}{ French Creek } \\
\hline Quarry Road & $1 \mathrm{E}-05$ & $2 E+00$ & 4E-05 & $1 E+00$ & $91 \%$ & $99 \%$ \\
\hline $\mathrm{FCO} 2$ & $1 \mathrm{E}-04$ & $4 E+00$ & $5 \mathrm{E} 07$ & $<1 E-02$ & $0 \%$ & $0 \%$ \\
\hline Lower & $2 E-05$ & $2 E+00$ & $5 E-05$ & $2 E+00$ & $73 \%$ & $86 \%$ \\
\hline \multicolumn{7}{|c|}{ Other On-Site Surface Water } \\
\hline Flightline Pond & $3 E-07$ & $<1 \mathrm{E}-02$ & $1 E-06$ & $<1 E-02$ & $0 \%$ & $0 \%$ \\
\hline Lily Lake & $<1 \mathrm{E}-07$ & $<1 \mathrm{E}-02$ & $1 E-06$ & $<1 E-02$ & $0 \%$ & $0 \%$ \\
\hline Upper Moose Creek & $2 \mathrm{E}-06$ & $1 \mathrm{E}-01$ & $8 E-06$ & $8 E-02$ & $0 \%$ & $0 \%$ \\
\hline \multicolumn{7}{|c|}{ Groundwater } \\
\hline North Boundary Wells & $<1 E-07$ & $<1 \mathrm{E}-02$ & $<1 E-07$ & $<1 E-02$ & $0 \%$ & $0 \%$ \\
\hline $\begin{array}{l}\text { The contribu } \\
\text { totals. }\end{array}$ & $m$ & ct & & re subtra & & \\
\hline
\end{tabular}


Table 2.2. Cancer Risk and Hazard Index at Lower Garrison Slough (USAF 1995b)

\begin{tabular}{|c|c|c|c|c|c|c|}
\hline \multirow{3}{*}{ Exposure Pathway } & \multicolumn{6}{|c|}{ Land Use Scenario } \\
\hline & \multicolumn{2}{|c|}{ Current Recreational } & \multicolumn{2}{|c|}{ Future Recreational } & \multicolumn{2}{|c|}{ Future Residential } \\
\hline & $\begin{array}{l}\text { Cancer } \\
\text { Risk }\end{array}$ & $\begin{array}{l}\text { Hazard } \\
\text { Index }\end{array}$ & $\begin{array}{l}\text { Cancer } \\
\text { Risk }\end{array}$ & $\begin{array}{l}\text { Hazard } \\
\text { Index }\end{array}$ & $\begin{array}{l}\text { Cancer } \\
\text { Risk }\end{array}$ & $\begin{array}{l}\text { Hazard } \\
\text { Index }\end{array}$ \\
\hline Ingestion of fish & 1E-03 & $2 E+02$ & $4 \mathrm{E}-03$ & $2 \mathrm{E}+02$ & NC & NC \\
\hline Ingestion of surface water & $<1 \mathrm{E}-07$ & $<1 \mathrm{E}-02$ & $<1 \mathrm{E}-07$ & $<1 \mathrm{E}-02$ & NC & NC \\
\hline $\begin{array}{l}\text { Dermal contact with } \\
\text { surface water }\end{array}$ & $<1 \mathrm{E}-07$ & $<1 \mathrm{E}-02$ & $<1 \mathrm{E}-07$ & $<1 \mathrm{E}-02$ & NC & NC \\
\hline Ingestion of sediments & $1 \mathrm{E}-05$ & $2 E+00$ & 3E-05 & $1 E+00$ & NC & $\mathrm{NC}$ \\
\hline $\begin{array}{l}\text { Dermal contact with } \\
\text { sediments }\end{array}$ & $4 \mathrm{E}-06$ & $6 E-01$ & $1 E-05$ & $5 \mathrm{E}-01$ & NC & NC \\
\hline Ingestion of groundwater & NA & NA & NA & NA & NA & NA \\
\hline $\begin{array}{l}\text { Dermal contact with } \\
\text { groundwater }\end{array}$ & NA & NA & NA & NA & NA & NA \\
\hline $\begin{array}{l}\text { Summation for all exposure. } \\
\text { pathways }\end{array}$ & 1E-03 & $2 E+02$ & 4E-03 & $2 E+02$ & NA & NA \\
\hline $\begin{array}{l}\text { Summation - site } \\
\text { background metals }\end{array}$ & $1 \mathrm{E}-03$ & $2 E+02$ & 4E-03 & $2 E+02$ & NA & NA \\
\hline \multicolumn{7}{|c|}{$\begin{array}{l}\text { Note: The reasonable maximum exposure case is used for future residential land use scenario. } \\
\text { NC: Not analyzed because the pathway was not considered complete under this land use } \\
\text { NA: Chemical data for this medium was not available. }\end{array}$} \\
\hline
\end{tabular}

\subsection{CHEMICALS OF CONCERN}

Site contamination at Eielson AFB is due to past base activities that dictate, in turn, the potential contaminants of concern. The principal contaminants of concern are:

- Benzene, toluene, ethylbenzene, and xylene (BTEX) and lead, which are components of fuels that have been leaked or spilled

- Chlorinated solvents that have been leaked, spilled, or discarded

- PAHs that have resulted from the incomplete combustion of hydrocarbons

- Pesticides that have been applied at the base

- PCBs that have been used and stored at the base.

Elevated levels of inorganic chemicals (such as, arsenic, manganese) have been noted in the soils and waters of the base. The OU 2 BLRA (USAF 1993) presents evidence indicating these elevated levels are not due to base activities. Thus, they have not been considered in this FS. 
The chemicals of concern for the Garrison Slough area based on recent findings. Those chemicals presented in the Surface Water and Sediment Investigation Draft Report (USAF 1994d), the RI (USAF 1995a), the Screening Baseline Risk Assessment - (USAF 1994a), and the Biological Risk Assessment (USAF 1995d) are summarized in Table 2.3. However, based on the Baseline Risk Assessment (USAF 1995b) PCBs in sediment and fish are the real risk drivers and, thus, are the only target contaminants to be further evaluated for remediation.

\subsection{APPLICABLE OR RELEVANT AND APPROPRIATE REQUIREMENTS}

SARA requires that remedial actions at Superfund sites achieve a cleanup level that protects human health and the environment. In addition, cleanups must attain legally the ARARs, which are promulgated under federal or state law, unless a waiver is warranted.

Nonpromulgated advisories or guidance are referred to as to-be-considered criteria (TBCs) that may also be incorporated into the evaluation of potential remedies. Superfund remedies are not required to meet TBCs, but they may be used in the selection of remedies in the absence of applicable or sufficiently protective ARARs.

There are three general types of ARARs: chemical-specific, location-specific, and action-specific. Chemical-specific ARARs are usually health- or risk-based concentration limits for specific hazardous substances in various environmental media (such as, water and soils). Location-specific ARARs impose restrictions on certain types of activities, based on site characteristics. Action-specific ARARs are requirements triggered by the type of remedial activities under consideration. Federal and state environmental laws often do not neatly fall into a single category.

The sitewide RI has identified contaminants in surface water, sediment, and aquatic biota at Eielson AFB. The nature and magnitude of the risks to human health and the environment from the contaminants are evaluated in the sitewide biological and human health BLRAs.

Potential chemical, location, and action-specific ARARs for remedial actions considered in this FS are discussed as follows.

Table 2.3. Chemicals of Concern for Garrison Slough

\begin{tabular}{|l|l|l||}
\hline \multicolumn{1}{|c|}{ Sediment } & \multicolumn{1}{|c|}{ Surface Water } & \multicolumn{1}{c|}{ Fish } \\
\hline \hline PCBs & Pesticides & PCBs \\
\hline Pesticides & & Pesticides \\
\hline & & PAHs \\
\hline
\end{tabular}




\subsubsection{Chemical-Specific Requirements}

Chemical-specific ARARs for groundwater, surface water, and petroleum-contaminated soils identified for Eielson AFB are described in the following paragraphs.

Groundwater. At Eielson AFB, the aquifer system is used as a drinking water supply. Drinking water standards apply to the point of use and not to the aquifer. However, the federal 140 CFR $141)$ and state (18 ACC 80 ) drinking water standards may be considered relevant and appropriate to the aquifer. Drinking water standards are listed in Table 2.4. The only MCLs that are typically exceeded by groundwater at Eielson AFB are those for manganese and iron. High manganese, arsenic, and iron concentrations are typical of background conditions for Eielson AFB and the Fairbanks area (USAF 1995a).

Groundwater is protected in accordance with the Alaska Water Quality Standard (18 ACC 70). Groundwater is protected for Class (1)(A), water supply Standards for toxic and deleterious substances, petroleum hydrocarbons, and oil and grease are identified in Table 2.5.

Surface Water. Section 304 of the Clean Water Act required EPA to establish criteria for water quality that will lead to the protection of human health and aquatic life. These criteria were derived from the evaluation of the latest scientific knowledge on the kind and extent of all identifiable effects of a contaminant in water, including effects on invertebrates, fish, wildlife, plants, and humans.

The EPA ambient water quality criteria (AWOC) for contaminants identified in surface water during the sitewide RI are listed in Table 2.4. Table 2.4 also includes the highest surface water concentrations measured at Eielson AFB in 1993 and 1994. Arsenic and manganese exceeded the human health criteria at all locations except Piledriver Slough and Flightline Pond, and iron exceeded the freshwater chronic AWOC and human health criteria everywhere except at Piledriver Slough and Flightline Pond. As noted previously, iron, manganese, and arsenic concentrations are typical of background conditions at Eieison AFB. The detection limits for some metals (antimony, cadmium, and silver) exceeded some of the AWOC.

Benzene slightly exceeded the value for the protection of human health (consumption of water and organisms) at one location (GSO1) in one year (1993). Other Volatile Organic Compounds (VOCs) were below AWOC. Where detected, the pesticides 4,4'-DDD and 4,4'-DDE exceeded the human health AWOC. The pesticide 4,4'-DDD was detected at six Garrison Slough and two French Creek stations, and 4,4'-DDE was detected at four Garrison Slough stations (USAF 1995a). Dieldrin exceeded the freshwater chronic AWOC and the human health criteria at FCO2 in 1993. Dieldrin was not detected at this site in 1994 (detection limit [DL] $=0.1 \mu \mathrm{g} / \mathrm{L}$ ).

The State of Alaska has promulgated water quality criteria for specific classes of protected water use, and has adopted a nondegradation policy for waters of higher quality than the criteria (18 AAC 70). The Alaska water quality standards that pertain to the contaminants of concern identified in surface water at Eielson AFB are listed in Table 2.5. Surface waters at Eielson AFB are protected for Classes (1)(A) Water Supply, (1)(B) Water Recreation, and (1)(C) Growth and Propagation of Fish, Shellfish, Other Aquatic Life, and Wildlife. For most classes of water use, concentrations of toxic and deleterious substances may not exceed Alaska drinking water standards, or where those standards do not exist, EPA water quality criteria (Table 2.4). Surface waters at Eielson AFB do not exceed drinking water standards, with the exception of arsenic, iron, and manganese (secondary standards). EPA human health water quality criteria are exceeded for 
Table 2.4. EPA Ambient Water Quality Criteria for Contaminants Identified in Surface Water at Eielson AFB

\begin{tabular}{|c|c|c|c|c|c|c|c|}
\hline \multirow[b]{4}{*}{ Contaminant } & \multirow[b]{4}{*}{$\begin{array}{c}\text { Maximum } \\
\text { Concentration }\left(\mu_{\theta} / L\right)\end{array}$} & \multirow[b]{4}{*}{ Location, Yoar } & \multicolumn{4}{|c|}{ Concentration $\left(\mu_{g} / L\right)$} & \multirow[b]{4}{*}{$\begin{array}{l}\text { Drinking Water } \\
\text { Standard }(\mathrm{MCL})^{\text {(t) }}\end{array}$} \\
\hline & & & \multicolumn{2}{|c|}{ Freshwater Aquatic Life Criteriald } & \multirow{2}{*}{\multicolumn{2}{|c|}{$\begin{array}{c}\begin{array}{c}\text { Human Health, } 10^{-6} \text { Risk for } \\
\text { Carcinogens }\end{array} \\
\text { National Toxice Rule }\end{array}$}} & \\
\hline & & & \multirow[b]{2}{*}{ Acute } & \multirow[b]{2}{*}{ Chronic } & & & \\
\hline & & & & & $\begin{array}{l}\text { Water and } \\
\text { Organisms }\end{array}$ & $\begin{array}{l}\text { Organisms } \\
\text { Only }\end{array}$ & \\
\hline Antimony & $<69.4$ & NA & NA ${ }^{\text {ld }}$ & NA & 14 & 4300 & 6 \\
\hline Arsenic & 17 & GSO2, 1993 & 360 (As III) & 190 (As III) & 0.018 & 0.14 & 50 \\
\hline Barium & 210 & GSO0, 1993 & NA & NA & 2000 (MCL) & NA & 2000 \\
\hline Beryllium & 1.4 & MC01, 1993 & NA & NA & $W^{191}$ & $w$ & 4.0 \\
\hline Cadmium & $<4.7$ & NA & 1.79 & 0.66 & w & $w$ & 5.0 \\
\hline Chromium & 6.1 & FCBG, 1993 & $\begin{array}{l}984(\mathrm{Cr} \text { III) } \\
16(\mathrm{Cr} \text { VII } \\
\end{array}$ & $\begin{array}{l}117(\mathrm{Cr} I I I) \\
11(\mathrm{Cr} \mathrm{VII})\end{array}$ & $w$ & $w$ & 100 \\
\hline Copper & 3.8 & FCBG, 1993 & 9.22 & 6.64 & 1300 & NA & $\begin{array}{l}1300^{(4)} \\
1000 \mathrm{SMCL}^{(1)}\end{array}$ \\
\hline Iron & 8200 & GSO2, 1993 & NA & 1000 & 300 (SMCL) & NA & $300 \mathrm{SMCL}$ \\
\hline Lead & 0.91 & GSOO, 1993 & 33.78 & 1.32 & $w$ & $w$ & $16^{14}$ \\
\hline Manganese & 1800 & GSO0, 1993 & NA & NA & 50 (SMCL) & 100 (marine) & $50 \mathrm{SMCl}$ \\
\hline Nickol & $<17.9$ & NA & 789 & 87.71 & 610 & 4600 & NA \\
\hline Silver & 2.9 & FCO3, 1993 & 1.23 & NA & NA & NA & $100 \mathrm{SMCL}$ \\
\hline Zinc. & 8.7 & GSO5, 1993 & 65.04 & 68.91 & NA & NA & $5000 \mathrm{SMCL}$ \\
\hline Benzene & 1.8 & GSO1, 1993 & NA & NA & 1.2 & 71 & 5.0 \\
\hline TCE & 0.75 & GSO5, 1994 & NA & NA & 2.7 & 81 & 5.0 \\
\hline Mothylene Chloride & 0.94 & FCO2, 1993 & NA & NA & 4.7 & 1600 & 5.0 \\
\hline Totrachloroethylene & 0.071 & PSO1, 1993 & NA & NA & 0.8 & 8.85 & 5.0 \\
\hline Dieldrin & 0.028 & FCO2, 1993 & 2.6 & 0.0018 & 0.00014 & 0.00014 & NA \\
\hline 4,4'-DDD & 0.062 & eso1, 1893 & NA & NA & 0.00083 & 0.00084 & NA \\
\hline 4,4'-DDE & 0.0035 & GSO3, 1993 & NA & NA & 0.00059 & 0.00059 & NA \\
\hline $\begin{array}{l}\text { (a) EPA Region IV To } \\
\text { (b) } \mathrm{MCL}=\text { Maximum } \\
\text { (c) } \mathrm{NA}=\text { Not applice } \\
\text { (d) } \mathrm{W}=\text { Criteria with } \\
\text { (o) Action level: cone } \\
\text { (f) } \mathrm{SMCL} \text { = Seconde }\end{array}$ & $\begin{array}{l}\text { ance Spreadsheet, Jant } \\
\text { nant Level, federal } 140 \\
\text { National Toxics Rule. } \\
\text { allowable in not more t }\end{array}$ & $\begin{array}{l}\text { N } 1996 . \\
R \text { 141) and state I } \\
\text { an } 10 \% \text { of the sam }\end{array}$ & AAC 80) drint & vater standards. & & & \\
\hline
\end{tabular}


Table 2.5. Alaska Water Quality Criteriaa ${ }^{(8)}$

\begin{tabular}{|c|c|c|c|}
\hline (1) $F$ & Fresh Water Uses & Toxic and Other Deloterious Organic and Inorganic Substances & Petraleum Hydrocarbons, Oils and Grease \\
\hline (A) & $\begin{array}{l}\text { Water Supply } \\
\text { (i) drinking, culinary, and food } \\
\text { procossing }\end{array}$ & $\begin{array}{l}\text { Substances may not exceed Alaska Drinking Water Standards (18 AAC 80) or, where } \\
\text { those standards do not exist, EPA Quality Criteria for Water. }\end{array}$ & $\begin{array}{l}\text { May not cause a visible sheen upon the surface of } \\
\text { the water. May not exceed concentrations that } \\
\text { individually or in combination impart odor or taste } \\
\text { as determined by organoleptic tests. }\end{array}$ \\
\hline (A) & $\begin{array}{l}\text { Water Supply } \\
\text { (ii) agriculture, including irrigation } \\
\text { and stock wotering }\end{array}$ & $\begin{array}{l}\text { Same as }(1)(A)(i) \text { where contact with a product destined for human consumption is } \\
\text { present. Same as (1)(C) or Federal Water Pollution Control Administration, Water } \\
\text { Quality Criteria(WOC/FWPCA), as applicable to substances for stockwaters; } \\
\text { concentrations for irrigation waters may not exceed WOC/FWPCA or WOC } 11972 \text {. }\end{array}$ & $\begin{array}{l}\text { May not cause a visible sheen upon the surface of } \\
\text { the water. }\end{array}$ \\
\hline (A) & $\begin{array}{l}\text { Water Supply } \\
\text { (iii) aquaculture }\end{array}$ & Same as (1)(C). & $\begin{array}{l}\text { Total aqueous hydrocarbons (TAqH) in the water } \\
\text { column may not exceed } 16 \mu \mathrm{g} / \mathrm{l} \text {. There may be no } \\
\text { concentrations of petroleum hydrocarbons, animal } \\
\text { fats, or vegetable oils in shoreline or bottom } \\
\text { sediments that cause deleterious effects to aquatic } \\
\text { life. Surface waters and adjoining shorelines must } \\
\text { be virtually free from floating oil, film, sheen, or } \\
\text { discoloration. }\end{array}$ \\
\hline (A) & $\begin{array}{l}\text { Water Supply } \\
\text { (iv) industrial }\end{array}$ & Substances that pose hazards to worker contact may not be present. & May not make the water unfit or unsafe for the use. \\
\hline (B) & $\begin{array}{l}\text { Water Recreation } \\
\text { (i) contact recreation }\end{array}$ & Same as (1)(A)(i). & $\begin{array}{l}\text { May not cause a film, sheen, or discoloration on the } \\
\text { surface or floor of the water body or adjoining } \\
\text { shorelines. Surface waters must be virtually free } \\
\text { from floating oils. }\end{array}$ \\
\hline (B) & $\begin{array}{l}\text { Water Recreation } \\
\text { (ii) socondary recreation }\end{array}$ & Substances that pose hazards to incidental human contect may not be present. & Same as (1)(B)(i) \\
\hline (C) & $\begin{array}{l}\text { Growth and Propagation of Fish, } \\
\text { Shellfish, Other Aquatic Lifo, and } \\
\text { Wildlife }\end{array}$ & $\begin{array}{l}\text { Individual substances may not exceed criteria in EPA, Quality Criteria for Water or, if } \\
\text { those criteria do not exist, may not exceed the Primary Maximum Contaminant Levels } \\
\text { of the Alaska Drinking Water Standards (18 AAC 80). If those criteria are absent, or if } \\
\text { the department finds that the criteria are not appropriate for sensitive resident Alaskan } \\
\text { species, the department will, in its discretion, est ablish in regulation chronic and acute } \\
\text { criteria to protect sensitive and blologically important life stages of resident Alaskan } \\
\text { species, using mothods approved by EPA or altemate methods approved by the } \\
\text { department. There may be no concentrations of toxic substances in water or in } \\
\text { shoreline or bottom sediments, that, singly or in combination, cause, or reasonably can } \\
\text { be expected to cause, toxic effects on aquatic life, except as authorized by this } \\
\text { chapter. Substances may not be present in concentrations that individually or in } \\
\text { combination impart undesirable odor or taste to fish or other aquatic organisms, as } \\
\text { determined by either bioassay or organoleptic tests. }\end{array}$ & Same as (1)(A)(iii) \\
\hline
\end{tabular}


4,4-DDD, and 4,4'-DDE. The criteria for petroleum hydrocarbons, oil, and grease for all classes of water use in Garrison Slough are violated at some locations, where a visible sheen is present on the water.

Sediment. No chemical-specific ARARs for the contaminants of concern in freshwater sediment currently exist. The State of Alaska has established cleanup standards for leaks and spills of petroleum products from storage tanks. These standards are also used by ADEC as numeric guidance for the cleanup of petroleum products from other types of releases (18 AAC 75). The guidance includes numeric soil cleanup target levels for diesel range hydrocarbons $(100 \mathrm{mg} / \mathrm{kg})$ and gasoline range hydrocarbons $(100 \mathrm{mg} / \mathrm{kg})$, benzene $(0.1 \mathrm{mg} / \mathrm{kg})$ and total benzene, toluene, ethylbenzene, and xylene (BTEX) $(10 \mathrm{mg} / \mathrm{kg})$. The highest concentration of petroleum hydrocarbons detected in sediment at Eielson AFB in 1993 and 1994 was $41 \mathrm{mg} / \mathrm{kg}$ diesel range hydrocarbons in Flightline Pond, which is well below the ADEC target cleanup level.

Fish. No chemical-specific ARARs are defined for the contaminants of concern in aquatic biota. The Food and Drug Administration (FDA) action levels for the marketability of fish may be a TBC for the protection of human health. These levels are used as guidance to determine whether contaminated food should be removed from the marketplace. Sport fishing is common on Eielson AFB.

The action level for total DDT is $5 \mathrm{mg} / \mathrm{kg}$ wet weight (FDA Guideline 7420.08, 1978). The highest fish tissue total DDT concentration was about $2 \mathrm{mg} / \mathrm{kg}$ wet weight (USAF 1995a). No action level exists for PCBs or any PAH. The FDA, however, has established a temporary tolerance level for $P C B$ residues in food for human consumption until these contaminants are eliminated from the environment (21 CFR 109.30). The temporary tolerance level for PCB residues in the edible portion of fish and shellfish is $2 \mathrm{mg} / \mathrm{kg}$. PCBs in two grayling caught in lower Garrison Slough exceeded this level at 2.4 and $3.0 \mathrm{mg} / \mathrm{kg}$.

\subsubsection{Location-Specific Requirements}

The following location-specific requirements may apply to any action taken to remediate contaminated fish or sediments.

Floodplain or Stream. For activities on a floodplain, action must be taken to avoid adverse effects, minimize potential harm, and restore and preserve natural and beneficial values (40 CFR 6, Appendix A). Eielson AFB is located on the floodplain of the Tanana River.

Under the Fish and Wildlife Coordination Act, if any activity requires diversion, channeling, or other modification of a stream or river and affects fish or wildlife, action must be taken to protect the fish or wildlife (40 CFR 6.302).

Wetlands. Designated wetlands are protected under the Clean Water Act. Any remedial activities conducted in wetland areas must be implemented in a manner that avoids adverse effects, minimizes potential harm, and preserves and enhances the wetlands to the extent possible. Although permit requirements are waived under CERCLA, excavation or fill would require special planning and could require wetland replacement, if a significant area were affected. 


\subsubsection{Action-Specific Requirements}

Action-specific requirements for the treatment, storage, and disposal of PCB-contaminated material are derived from two sets of regulations: the Toxic Substances Control Act (TSCA) PCB regulations (40 CFR 761), and the Resource Conservation and Recovery Act (RCRA) land disposal restrictions (40 CFR 268).

TSCA requirements do not apply to PCBs at concentrations less than $50 \mathrm{ppm}$; however, PCBs can not be diluted to escape TSCA requirements. Response actions and clean up levels under CERCLA should evaluate the form and concentration of PCB contamination "as found" at the site (EPA $1990)$. Therefore, TSCA should apply to only a small stretch $(\sim 50 \mathrm{~m}$ [160 ft]) of Garrison Slough, where the sediment concentration equals or exceeds $50 \mathrm{mg} / \mathrm{kg}$.

Disposal of Non-Liquid PCB Waste With Concentrations Greater Than or Equal to $50 \mathrm{ppm}$ : Nonliquid PCB waste in the form of soil, rags, or other debris, with concentrations of $50 \mathrm{ppm}$ or greater are to be disposed of:

- in an incinerator (40 CFR 761.70);

- treated by an equivalent method (40 CFR 761.60(e)); or

- in a chemical waste landfill (40 CFR 761.75).

A special allowance is made under TSCA for dredge materials that contain PCBs with concentrations of $50 \mathrm{ppm}$ or greater. If, based on technical, environmental, and economic considerations, it can be shown that disposal in an incinerator or chemical waste landfill is not reasonable or appropriate and that an alternative disposal method will provide adequate protection to health and the environment, this alternate disposal method will meet the substantive requirements of TSCA (EPA, 1990; 40 CFR 761.60(a)). Since these showings are integral components of any remedy selected at a Superfund site, Superfund actions involving PCBcontaminated dredged material generally will be consistent with TSCA (EPA, 1990).

Storage For Disposal: If any contaminated sediments are stored prior to permanent disposal, those PCBs at concentrations of $50 \mathrm{ppm}$ or greater must be disposed of within one year after being placed in storage (40 CFR 761.65). The storage facility must comply with the following criteria (40 CFR 761.65(b)):

- adequate roof and walls to prevent rain water from reaching stored PCBs;

- adequate floor with continuous $15 \mathrm{~cm}(6 \mathrm{in.})$ high curbing;

- no drain valves, floor drains, expansion joints, etc. that would permit liquids to escape from the curbed area;

- floors and curbing of continuous smooth and impervious materials; and

- not located below the 100-year flood water elevation.

However, contaminated soil, rags, and debris may be temporarily stored (up to 30 days) in an area that does not comply with these facility criteria (40 CFR 761.65(c)). An interim remedy waiver under CERCLA could also be invoked to waiver. some of these requirements. 
On-site Disposal or Containment: General requirements for chemical waste landfills used for the disposal of PCBs (i.e., $\geq 50$ ppm) include the following (40 CFR 761.75):

- Located in thick, relatively impermeable formation, such as large clay pans, or on soil with high clay and silt content, or use of a synthetic membrane liner.

- Bottom of the landfill liner system or natural in-place soil barrier at least $15 \mathrm{~m}(50 \mathrm{ft})$ above the historical high groundwater table.

- Adequate surface water controls. If located below the 100-year floodwater elevation, diversion

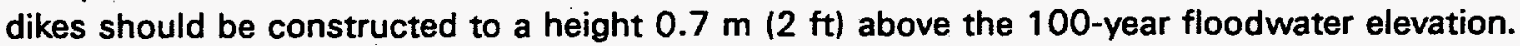

- Located in an area of moderate to low relief to minimize erosion and mass wasting.

- Surface water monitoring at a minimum of three points.

- Leachate collection/monitoring system.

- Fencing.

Where superfund remedial action will leave PCBs in place or where PCB-contaminated material is excavated, treated, and re-disposed at concentrations that still pose a threat, capping consistent with RCRA chemical waste landfill requirements is generally appropriate (EPA 1990). Long-term management control for PCB-contaminated material generally will also parallel RCRA closures. However, it may be appropriate to waive certain TSCA chemical waste landfill requirements 440 CFR 761.75), such as liners, when containing existing waste disposal sites.

PCB contaminated RCRA hazardous waste (as defined by 40 CFR 261) may be subject to land disposal restrictions if:

- the concentration of PCBs in liquid hazardous waste is greater than or equal to $50 \mathrm{ppm}$; or

- the total concentration of Halogenated Organic Compounds (HOCs) in non-liquid hazardous waste exceeds $1000 \mathrm{ppm}$.

The total concentration of HOCs in sediment from Garrison Slough would not exceed 1000 ppm; therefore, land disposal restriction should not apply.

\subsection{REMEDIAL ACTION OBJECTIVES}

RAOs are media-specific objectives developed from CERCLA remedial action goals, consideration of potential risk, and regulatory requirements. The BLRA (USAF 1995b) calculated the excess cancer risk to humans from the ingestion of PCB contaminated fish from the lower reach of Garrison Slough may be on the order of $10^{-3}$. Thus, this stretch of the slough is being considered for remedial action.

A strong spatial relationship exists between PCB concentrations in sediment and in fish at Garrison Slough (Figure 2.1). The highest sediment concentrations were measured near Arctic Avenue, and the highest fish tissue concentrations were measured in fish caught in the same reach of the 


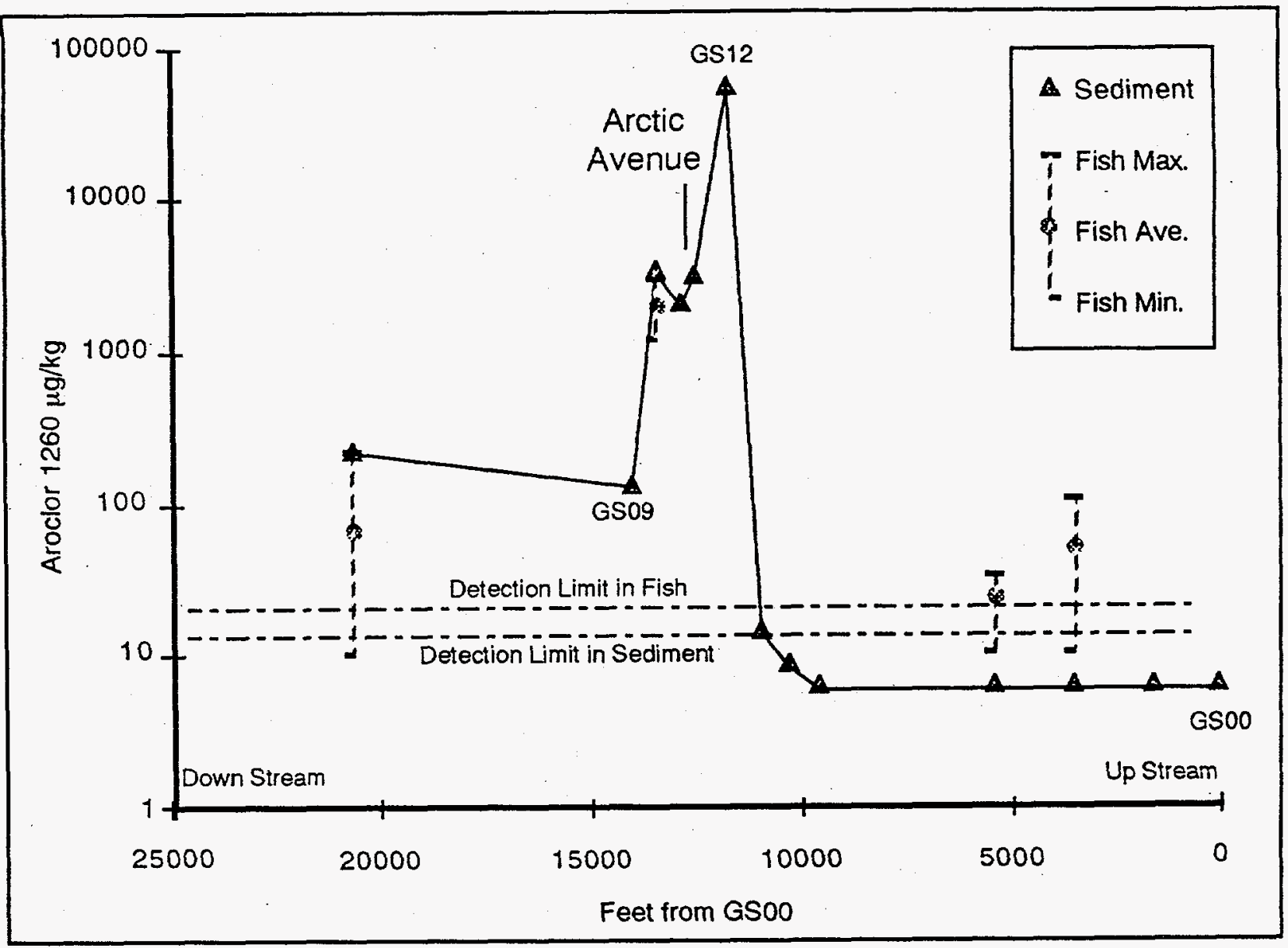

Figure 2.1. Relationship Between Sediment and Fish Concentrations in Garrison Slough, Based on 1994 Sediment and Fish Tissue Sampling.

slough. Both sediment and tissue concentrations were orders of magnitude lower at other sampling locations within the slough. Additionally, concentrations of PCBs in fish tissue were approaching background levels in tributary streams upstream of the Garrison Slough-Moose Creek confluence. PCBs were detected in invertebrates only from lower Garrison Slough (USAF, 1995a). Therefore, it is assumed a complete bioaccumulation pathway exists from the sediment to the fish in lower Garrison Slough, and the high tissue concentrations in fish are a direct result of exposure of fish and their food source to the contaminated sediment. The uptake of PCBs by fish may occur through incidental ingestion of contaminated sediment while feeding, gill exchange with surface waters, and ingestion of contaminated water and prey. Although PCBs were not detected in surface water samples, they may be present at concentrations below the detection limit and contribute to their bioaccumulation in fish. Because fish inhabiting Garrison Slough will presumably continue to accumulate PCBs from accumulated sediment either directly or indirectly (prey and interstitial/surface water), both the fish and the sediments are the focus for development of RAOs.

State of Alaska or federal freshwater sediment cleanup criteria for PCBs do not currently exist. In its guidance for PCB-contaminated sites, EPA (1990) uses the equilibrium partitioning approach to 
derive sediment quality criteria ( $\mathrm{SOC}$ ) that will achieve the chronic ambient water quality criteria of $.014 \mu \mathrm{g} / \mathrm{L}$ in interstitial water (EPA 1990). EPA recommends, if the sediment concentration at a site exceeds the SOC value, water column species should be monitored to determine if prey contain unacceptable contaminant levels. The Air Force has monitored water column species in lower Garrison Slough, and it appears the PCB levels in fish tissue may pose an unacceptable risk to human health. EPA guidance, however, does not suggest a method for determining a cleanup criterion if unacceptable contaminant levels in water column species are found. In addition, EPA points out that an established cleanup concentration, based on total PCB, may show little relationship to biological phenomena because not all PCB congeners have the same toxicological effects.

No direct relationship can be established between sediment PCB concentration and resultant fish tissue concentration in lower Garrison Slough. Any relationship would be time, concentration, and species dependent, and the relative importance of each variable is not known. Therefore, it is not possible to derive a reliable site-specific sediment cleanup criterion that could translate into fish tissue concentrations that would not present an unacceptable risk to human health.

Another approach to developing a preliminary remediation goal for sediment is to reduce the mass of PCBs available for fish uptake. This approach assumes that removing or isolating the sediment with the highest PCB concentrations and reducing the overall mass available for uptake by water column organisms would, over time, lead to a reduction in the average concentration of PCBs in the fish population. Because of the long half-life of PCBs in aquatic organisms (approximately 8 years [De Boer et al. 1994]], a reduction in average fish tissue concentrations for the general population may not be evident until fish with high body burdens either die or migrate out of the system.

The primary goal of remediation is to reduce the potential risk to human health from the consumption of PCB-contaminated fish. This goal can be achieved by:

- Preventing ingestion of contaminated fish from Lower Garrison Slough

- Reducing the highest concentrations and mass of PCBs available for uptake by water column organisms, including fish, so that concentrations of PCBs in the area's fish population will eventually achieve acceptable tissue concentrations.

To achieve the remediation goal and meet the general goals of the CERCLA program, RAOs were developed to define media-specific contaminant concentrations or mass reduction goals. Table 2.6 presents these RAOs.

Table 2.6. Remedial Action Objectives

\begin{tabular}{||l|l|l|l|l|}
\hline Medium & \multicolumn{1}{|c|}{$\begin{array}{c}\text { Contaminant of } \\
\text { Concern }\end{array}$} & \multicolumn{1}{|c|}{$\begin{array}{c}\text { Exposure } \\
\text { Route }\end{array}$} & \multicolumn{1}{|c|}{ Receptor } & \multicolumn{1}{|c|}{$\begin{array}{c}\text { Preliminary } \\
\text { Remediation Goal }\end{array}$} \\
\hline \hline Fish & $\begin{array}{l}\text { PCBs } \\
\text { (Aroclor 1260) }\end{array}$ & Food Chain & Human & $\begin{array}{l}0.69 \mu \mathrm{\mu} / \mathrm{kg} \\
\text { (wet weight) }\end{array}$ \\
\hline Sediment & $\begin{array}{l}\text { PCBs } \\
\text { (Aroclor 1260) }\end{array}$ & Food Chain & $\begin{array}{l}\text { Human (through } \\
\text { fish uptake) }\end{array}$ & $\begin{array}{l}\text { Reduce the peak } \\
\text { concentrations and a } \\
\text { preponderance of the } \\
\text { PCB mass }\end{array}$ \\
\hline
\end{tabular}


The PRG for fish was developed based on a back calculation for the fish tissue concentration that would produce a total excess cancer risk of less than $10^{-6}$. This calculation used a recreational exposure scenario (for example, ingestion of fish by an adolescent [300 grams of fish, 30 times/year for 12 years]; using a body weight of $22.6 \mathrm{~kg}$ and a life span of 70 years [USAF 1995a]).

The peak concentrations and mass reduction goal is based on the strong spatial relationship between sediment PCB concentrations, invertebrate concentrations, and fish tissue concentrations. Conceptually, the accumulation of PCBs in fish is through their ingestion of contaminated sediment, prey, or surface water, and/or gill exchange. As Figure 2.1 shows, the major contamination peak (and a preponderance of the PCB mass) lies upstream of Arctic Avenue. A plot of the cumulative mass percentage vs. distance from the start of $P C B$ contamination (Figure 2.2) using recently acquired sampling results ${ }^{(a)}$ indicates that approximately $80 \%$ of the PCB mass lies upstream from Arctic Avenue. At this point, the cumulative mass curve flattens out, indicating that less PCB mass is present for a given distance of the slough, and suggesting less return on the investment per the remediation dollars. Arctic Avenue is also a logical and convenient geographic barrier for cessation of remedial actions. Thus, for the purposes of this focused feasibility study, the RAO will be considered to be achieved by remediating the relatively short $(300-\mathrm{m}[1000-\mathrm{ft}])$ stretch of the slough just upstream of Arctic Avenue (Figure 1.3). Many assumptions and extrapolations are involved in defining this preliminary remediation goal; thus, any remediation scheme that may be adopted will require verification and, if necessary, further remediation.

\subsection{TARGET AREA FOR REMEDIAL ACTION}

An evaluation of the potential media, contaminants of concern, and areas to be targeted for remedial action was conducted based on:

- nature and extent of contamination described in the Surface Water and Sediment Investigation Draft Report (PNL 1994a), the technical memo: "Preliminary Assessment of PCB Sediment Contamination in Garrison Slough ${ }^{(b)}$," the Sitewide Remedial Investigation (RI) Report (USAF 1995a) (summarized in Section 1.2), and recent (Spring 1995) sediment sampling(a).

- findings in the Screening Baseline Risk Assessment (PNL 1994b), Biological Risk Assessment (PNL 1994c), and Sitewide Baseline Risk Assessment (USAF 1995b) (summarized in Section 2.2).

- chemical specific ARARs (outlined in Section 2.4)

- RAOs and PRGs (presented in Section 2.5).

(a) Personal communication with Steve McNiel (Eielson Air Force Base), via telephone and FAX on May 17 and 18, 1995.

(b) Technical Memo. "Preliminary Assessment of PCB Sediment Contamination in Garrison Slough, Eielson Air Force Base, Alaska". Prepared by the Pacific Northwest Laboratory, Richland, Washington, for the U. S. Air Force Environmental Restoration Program, Eielson Air Force Base, Alaska. 


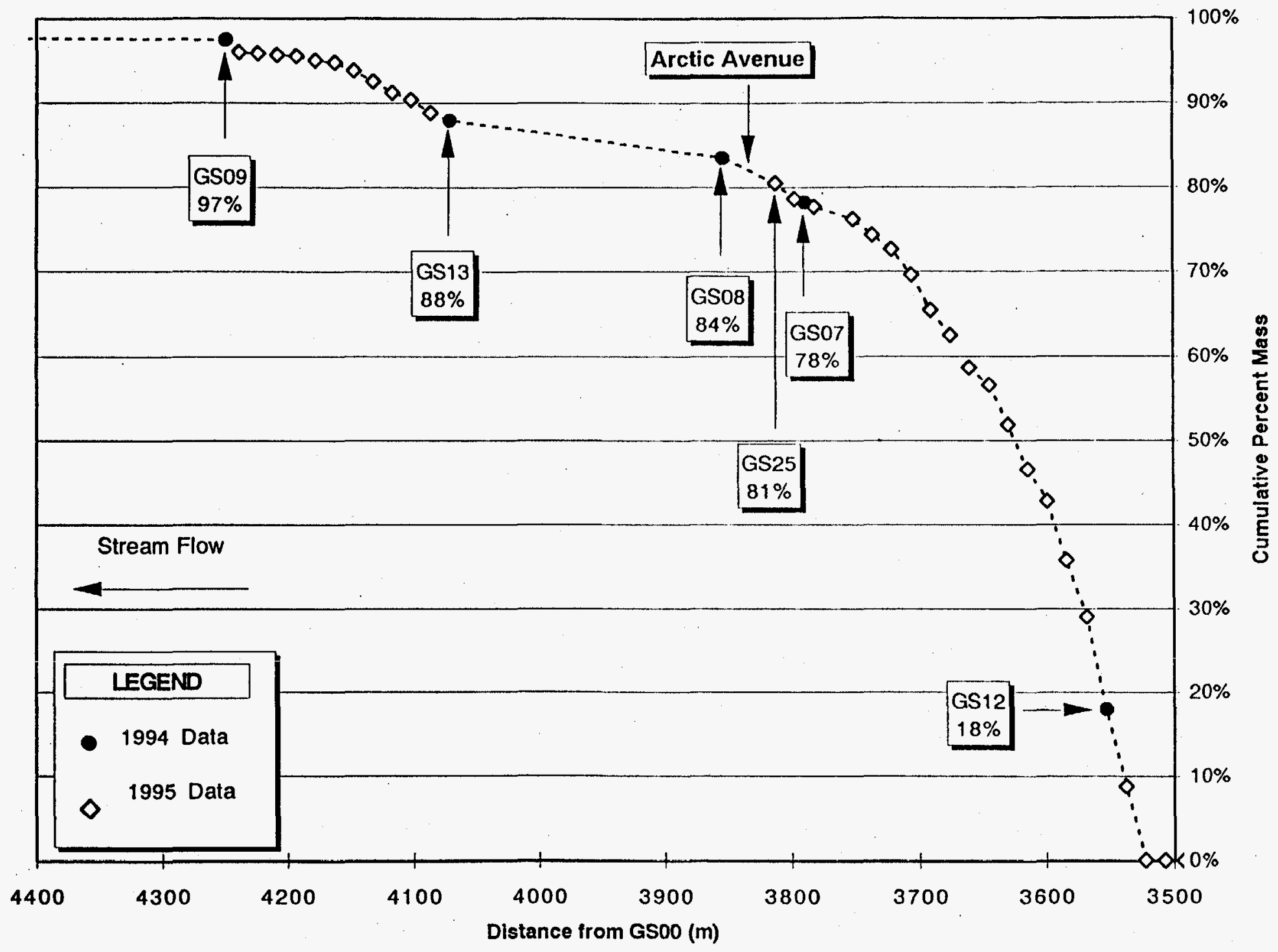

Figure 2.2. Cumulative Mass Percent of PCBs (includes recent [Spring 1995] sediment sampling data [open diamonds] received from Steve McNiel [Eielson Air Force Base], via telephone and FAX on May 17 and 18, 1995; refer to Appendix A). 
As indicated in the previous section, both fish and sediment are targeted for remedial action. The area of principal threat is located in the lower portion of Garrison Slough, just upstream of Arctic Avenue (Figure 2.1). This 300-m (1000-ft) stretch of the slough contains most of the contamination $(80 \%)$ present in bottom sediment. Assuming a stream channel $3.3 \mathrm{~m}(10 \mathrm{ft})$ wide filled with $0.6 \mathrm{~m}(2 \mathrm{ft})$ of contaminated sediment, would result in a volume estimate of $600 \mathrm{~m}^{3}$ $\left(780 \mathrm{yd}^{3}\right)$.

Many assumptions and extrapolations have been made regarding the impacts of remediating a relatively short distance of Garrison Slough on the reduction of PCB concentrations in fish tissue samples. Any remediation scheme that may be adopted for lower Garrison Slough will require verification and, if necessary, further remediation. 


\subsection{IDENTIFICATION AND SCREENING OF REMEDIAL TECHNOLOGIES}

The purpose of this section is to identify, develop, and evaluate a focused range of potentially applicable response actions, remedial technologies, and process options for Garrison Slough. Garrison Slough was selected for possible remediation because of potential human health risk from current and future unrestricted access and exposure to PCBs through the ingestion of contaminated fish.

The potential response actions, technologies, and process options identified in this section focus on those that are most viable for remediation of aquatic sediments and fish populations contaminated with PCBs and located in an active industrial area within the subarctic environment. The physical characteristics of the site, as well as ongoing base activities, greatly influence the effectiveness and implementability of many of the potential response actions and remedial technologies. The following site-specific factors are considered in the technology screening:

- The subarctic environment will generally reduce the rate of most natural or man induced biodegradation, and will limit certain types of excavation or dredging to a short field season. Surface water and sediment freezing may either hinder or facilitate certain types of excavation or spread of contamination. This situation will also strongly affect the type and design of surface caps that can be installed.

- Seasonally altered surface water flow rates affect stream erosion and resuspension of contaminated sediments.

- Garrison Slough is thought to be lower than the water table throughout the year over most of the slough's length (except perhaps near the water treatment plant [WTP] pond), and thus receives water from and acts as a drain for the shallow aquifer (PNL 1993b).

- The strong sorption characteristics of PCBs and the long-term presence of surface water overlying these contaminated sediments limits the viability of in situ sorption or leaching technologies.

- The lack of permitted hazardous waste incinerators which could receive PCB contaminated soil within Alaska markedly increases the cost of incineration alternatives because of the high mobilization or transportation costs.

- No permitted Toxic Substances Control Act/Resource Conservation and Recovery Act (TSCA/RCRA) chemical waste landfills are located in Alaska. The absence of chemical waste landfills will markedly increase the cost of transportation and disposal.

This screening process focuses on identifying possible remedial technologies and process options to achieve the RAOs. A range of general response actions is reviewed and possible remedial technologies are identified for actions that seem most applicable to source reduction in aquatic sediments and fish populations in Garrison Slough.

The range of actions for sediment and fish remediation includes those actions that eliminate the need for long-term management, those that, use treatment as the primary component, and those that to the extent feasible, focus on containment. Only the lower portion of Garrison Slough, which 
is contaminated with PCBs, is considered in this FS. No other sites investigated as part of the sitewide RI/FS have been determined as posing an unacceptable risk to human health or the environment (USAF 1995b, USAF 1994e).

\subsection{RESPONSE ACTIONS AND TECHNOLOGIES FOR REMEDIATING THE FISH POPULATION}

Fish residing in lower Garrison Slough were found to contain PCB (Aroclor 1260) contamination in concentrations that pose a human health risk on the order of $10^{-3}$ excess cancers (USAF 1995b). Potential response actions, remedial technology types, and process options appropriate for meeting the remedial action objective for the fish population are presented in Table 3.1.

From this initial identification of possible response actions and remedial technologies, a limited set of technologies and process options was developed. An initial screening based on the technical feasibility of the potential technologies and process options is shown in Figure 3.1. Those technologies and process options not eliminated during this initial screening were then further evaluated for their effectiveness, implementability, and relative cost. This evaluation is shown in Figure 3.2.

\subsection{RESPONSE ACTIONS AND TECHNOLOGIES FOR REMEDIATING AQUATIC SEDIMENTS}

Aquatic sediment in Garrison Slough is believed to be the primary source of PCB (Aroclor 1260) contamination in the fish population. A point source for the PCB contamination appears to be located approximately $300 \mathrm{~m}(1000 \mathrm{ft})$ upstream of Arctic Avenue. Potential response actions, remedial technology types, and process options appropriate for meeting the remedial action objective for these aquatic sediments and the fish population are presented in Table 3.2.

From this initial identification of possible response actions and remedial technologies for aquatic sediments, a limited set of technologies and process options was developed. An initial screening based on the technical feasibility of the potential technologies and process options is shown in Figure 3.3. The technologies and process options not eliminated in this initial screening were then further evaluated for their effectiveness, implementability, and relative cost. This evaluation is presented in Figure 3.4. Those technologies/process options identified as being innovative, and thus not fully proven, were to be included in this second evaluation. Instead, they are discussed separately.

\subsection{INNOVATIVE TECHNOLOGIES}

Three innovative technologies/process options were identified for possible consideration in meeting the RAOs for sediment. A brief description of each follows.

\subsubsection{Algal Mats}

Microbial (algal) mats are natural heterotrophic communities dominated by cyanobacteria (blue-green algae). These complex laminated structures can be cultured by enriching a water surface with ensiled grass clippings. Specific microbes can then be cultured within the constructed 
cyanobacteria/silage mixture to address a specific remediation task. Bender (1993) has shown that constructed mats can degrade a wide variety of organic contaminants, including PCBs, in water or soil.

The effectiveness of this technology in meeting the RAO for sediment is uncertain, especially in an arctic environment. Some treatability studies would be necessary. However, the advantage of this technology is that it can work in place, without removal of the sediments, and without adversely affecting the stream's ecosystem. Depending on the efficiency, significant cost savings could be achieved using this technology.

\subsubsection{Ozone, Ultraviolet, Ultrasonics, and Ultrapure Water}

The Ozone, Ultraviolet, Ultrasonics, and Ultrapure Water process is a 2-stage system. First, the PCBs are removed from the sediment slurry $(30-40 \%$ solids) using ultrapure water as the solvent. Then the aqueous solution is treated with ozone, ultraviolet energy, and ultrasonics to oxidize the PCBs and transform them into carbon dioxide, water and harmless salts. The size of systems tested thus far have ranged from 0.03 to $15 \mathrm{~m}^{3} / \mathrm{hr}\left(1 \mathrm{ft}^{3} / \mathrm{hr}\right.$ to $27 \mathrm{cu} \mathrm{yd} / \mathrm{hr}$ ) (Boeve 1989).

One advantage of this system is that it can remediate the dredge materials directly, without dewatering. Another potential advantage is that it promises to produce no solvent or other waste streams that must be treated. However, treatability studies should be performed to determine the efficiency of the extraction and degradation rates, and to ensure that no harmful byproducts are produced.

\subsubsection{In Situ Reduction}

Reductive dechlorination of PCBs has been demonstrated to achieve performance levels that are considered equivalent to incineration for ex situ treatment. However, in situ application has not been proven. Detailed treatability studies would be required to demonstrate that concentration reductions can be achieved on a consistent basis for the site-specific conditions present at Eielson AFB.

As with most other in situ treatment technologies/process options considered for sediments of Garrison Slough, the stream would first have to be diverted, and perhaps the groundwater table lowered to dewater the sediments, prior to application of the technology. Thus, the use of this technology is not considered further in the development of remedial options. 
Table 3.1. Response Actions and Technologies for Remediation of the Fish Population

\begin{tabular}{|c|c|c|c|}
\hline $\begin{array}{c}\text { Remedial Action } \\
\text { Objective }\end{array}$ & $\begin{array}{l}\text { General Response } \\
\text { Actions }\end{array}$ & $\begin{array}{c}\text { Remedial } \\
\text { Technologies }\end{array}$ & Process Options \\
\hline \multirow{10}{*}{$\begin{array}{l}\text { Prevent } \\
\text { ingestion of fish } \\
\text { tissue having a } \\
\text { PCB } \\
\text { concentration } \\
\text { greater than } \\
0.69 \mu \mathrm{g} / \mathrm{mg} \text { (wet } \\
\text { weight) }\end{array}$} & No Action & No Action & No Action \\
\hline & \multirow[t]{2}{*}{ Institutional Controls } & Access Restrictions & Warning Signs and Fences \\
\hline & & Fishing Advisory/Restrictions & State Fishing Advisory/Restrictions \\
\hline & \multirow[t]{2}{*}{ Containment/lsolation } & \multirow[t]{2}{*}{ Fish Controls } & Fish Screens \\
\hline & & & Fish Control Dam \\
\hline & \multirow[t]{2}{*}{ Removal } & Collect and Remove Fish & Electroshock, Nets, Diversion \\
\hline & & Poison and Remove Fish & $\begin{array}{l}\text { Poison (Rotenone, Antimycin), } \\
\text { Nets, Diversion }\end{array}$ \\
\hline & $\begin{array}{l}\text { Ex-situ Treatment (in } \\
\text { conjunction with } \\
\text { removal) }\end{array}$ & Thermal Treatment & Incineration \\
\hline & \multirow[t]{2}{*}{$\begin{array}{l}\text { Disposal (in } \\
\text { conjunction with } \\
\text { removal) }\end{array}$} & \multirow[t]{2}{*}{ Landfill } & Chemical Waste Landfill \\
\hline & & & Solid Waste Landfill \\
\hline
\end{tabular}


GENERAL RESPONSE

REMEDIAL

PROCESS

TECHNOLOGY

OPTION

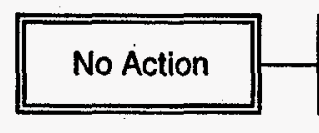

No Action
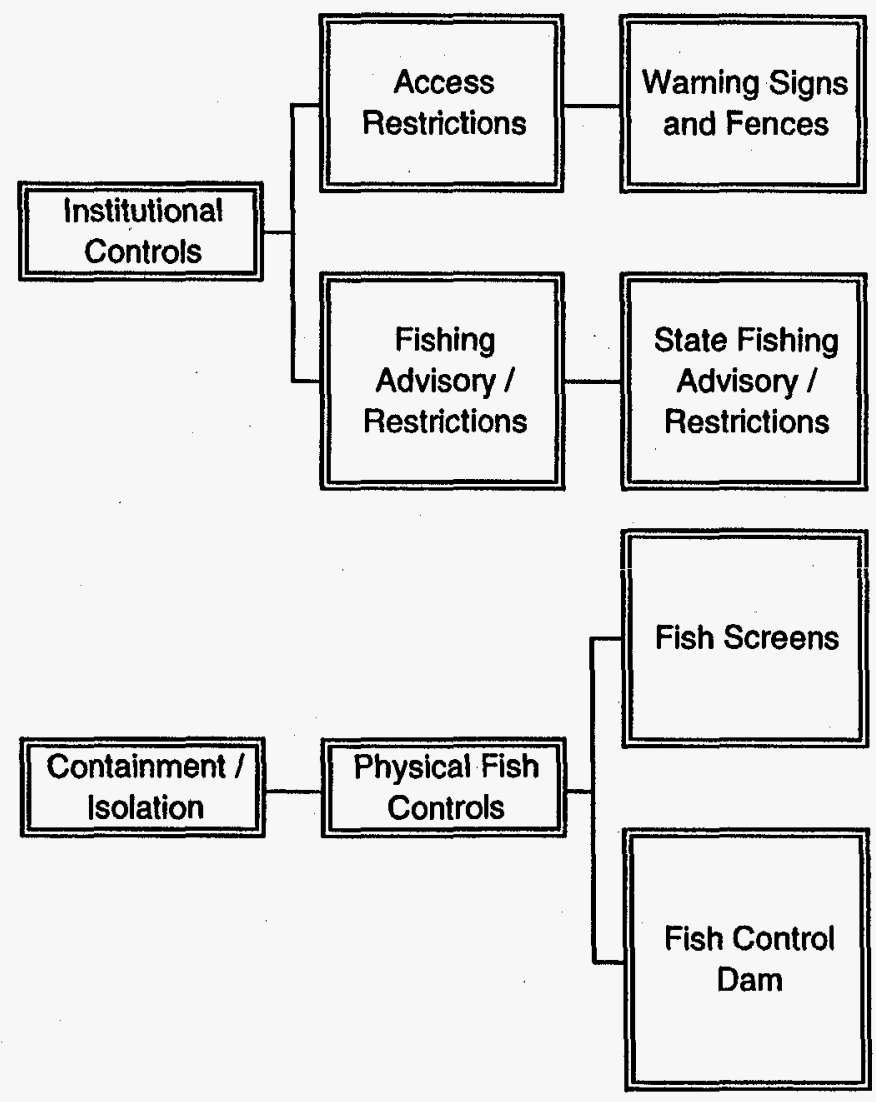

DESCRIPTION

No remedial actions. Includes continued monitoring.

Warning signs and security fences strategically placed along lower

Garrison Slough to restrict base and/or public fishing.

Advisory, restrictions, and limitations (eg. "Catch and Release") placed on fishing in lower Garrison Slough and other water bodies inhabited by contaminated fish.

Screens would be strategically placed across lower Garrison Slough to prevent contaminated fish from migrating offsite, and to prevent uncontaminated fish from migrating into contaminated areas.

A coffer dam would be constructed downstream of the contamination to prevent upstream migration of fish. Would prevent exposure of fish to the source of contamination.

\section{SCREENING COMMENTS}

Required under the NCP. Does not reduce risk.

Would reduce the risk of ingesting contaminated fish.

Would reduce the risk of ingesting contaminated fish. Would require State Department of Fish and Game action.

Reduces long-term human health risk due to ingestion of fish. Fish screens would likely clog with debris and require periodic maintenance. Effectiveness during high flows

Reduces long-term risk due to ingestion of fish. Would require some maintenance, though less than screens, since debris could flow over dam. Effectiveness during high flows uncertain.

Figure 3.1. Initial Screening of Technologies and Process Options for Remediation of Fish 


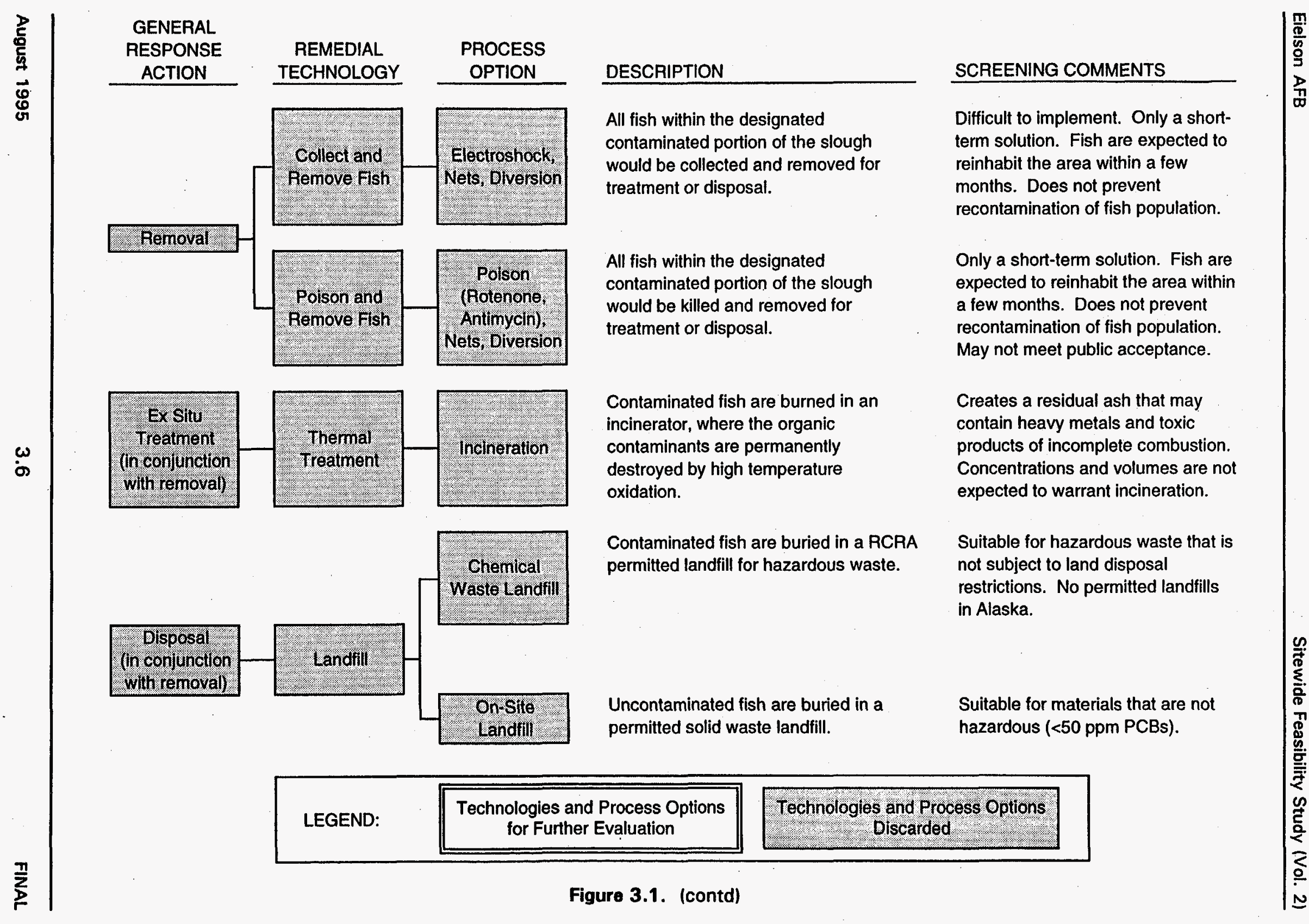


GENERAL

RESPONSE

ACTION

TECHNOLOGY
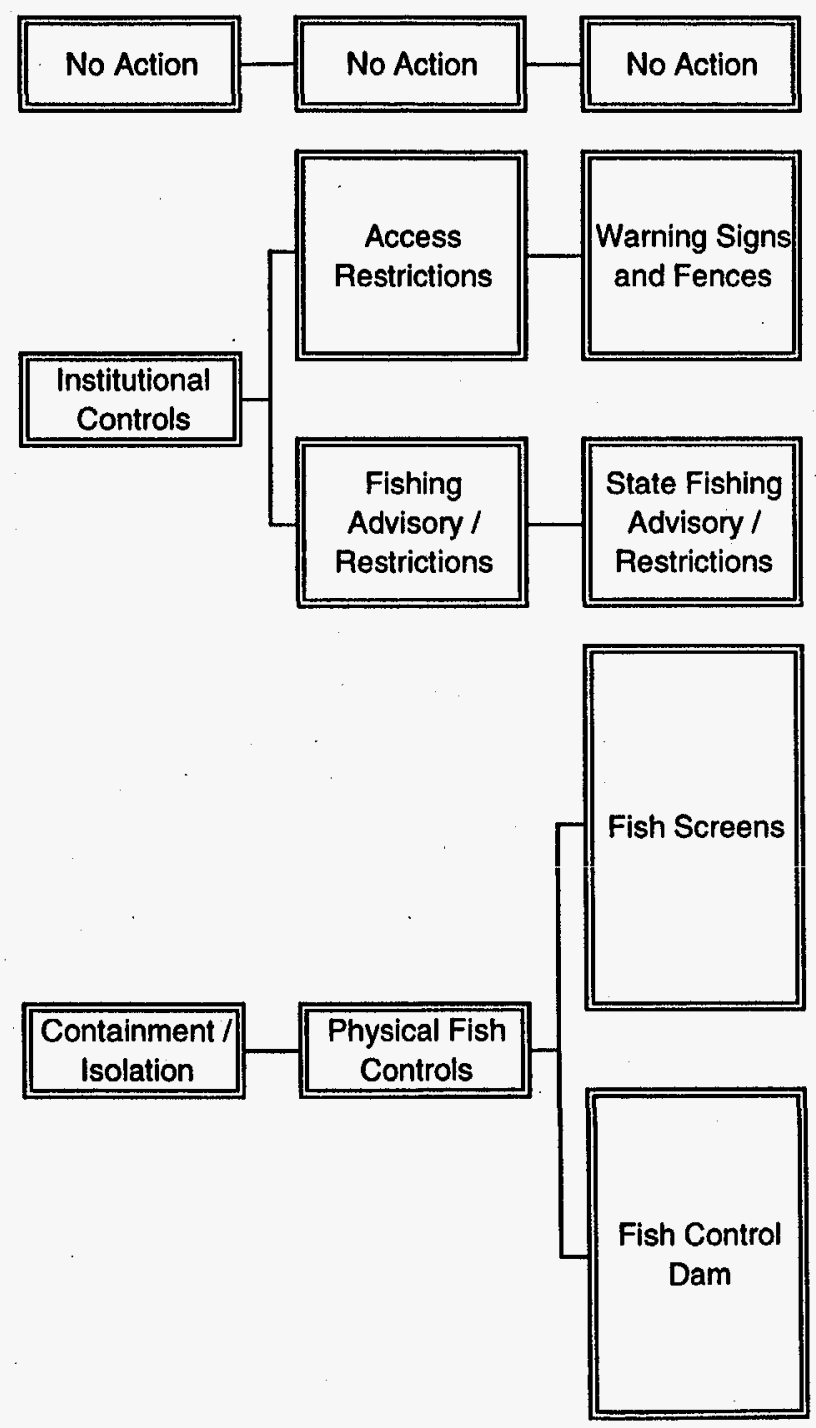

EFFECTIVENESS

Does not achieve remedial

objective.

Effective only for fish within the controlled area. Does not adequately address fish migration.

Effective.

Should be fairly effective over the long term (eg. one generation of fish); by reducing bioaccumulation of PCBs in uncontaminated adult fish downstream of screen. Prevents downstream migration of contaminated population.

Fairly effective over the long term (one fish generation), by reducing bioaccumulation of PCBs in uncontaminated fish downstream of dam. Has little short term effect on existing contaminated population.

\section{IMPLEMENTABILITY}

Easily Implemented;

acceptability uncertain.

Fairly easy to implement on base. Implementation off base

is uncertain. Difficult to

implement for entire migration

route.

Easy to implement on base; implementation and acceptability off base uncertain.

Fairly easy to implement. May require permitting/approval from State Department of Fish and Game, Corps of

Engineers, NOAA, etc.

Implementation may also

impact potential salmon

spawning areas.

Fairly easy to implement. May require permitting/approval from State Department of Fish and Game, Corps of

Engineers, NOAA, etc.

Implementation may also

impact potential salmon

spawning areas. $\cos T$

None.

Very low capital; very low

maintenance.

ssentially no capital; very low maintenance.

Low capital; low maintenance.

Figure 3.2. Evaluation of Process Options for Remediation of the Fish Population

Low capital; very low maintenance. 
Table 3.2. Response Actions and Technologies for Remediation of Aquatic Sediments

\begin{tabular}{|c|c|c|c|}
\hline $\begin{array}{l}\text { Remedial Action } \\
\text { Objective }\end{array}$ & $\begin{array}{c}\text { General Response } \\
\text { Actions }\end{array}$ & $\begin{array}{c}\text { Remedial } \\
\text { Technologies }\end{array}$ & $\begin{array}{l}\text { Process } \\
\text { Options }\end{array}$ \\
\hline \multirow{27}{*}{$\begin{array}{l}\text { Reduce the Peak } \\
\text { Concentrations and a } \\
\text { Preponderance }(80 \%) \\
\text { of the PCB Mass }\end{array}$} & No Action & No Action & No Action \\
\hline & \multirow[t]{3}{*}{ Institutional Controls } & \multirow[t]{3}{*}{$\begin{array}{l}\text { Access and Use } \\
\text { Restrictions }\end{array}$} & $\begin{array}{l}\text { Deed Notice on Land Use } \\
\text { Restrictions }\end{array}$ \\
\hline & & & $\begin{array}{l}\text { Warning Signs and } \\
\text { Fences }\end{array}$ \\
\hline & & & Base Regulations \\
\hline & \multirow[t]{14}{*}{ Containment//solation } & $\begin{array}{l}\text { Sedimentation } \\
\text { Controls }\end{array}$ & $\begin{array}{l}\text { Sedimentation basins and } \\
\text { diversion controls }\end{array}$ \\
\hline & & \multirow[t]{4}{*}{ Line Stream Bottom } & Culvert \\
\hline & & & Concrete \\
\hline & & & Synthetic Liner \\
\hline & & & Multilayer Porous Cap \\
\hline & & \multirow[t]{2}{*}{ Divert Stream } & Bypass Culvert/Pipeline \\
\hline & & & Excavate New Channel \\
\hline & & \multirow{7}{*}{$\begin{array}{l}\text { Cap Old Channel (in } \\
\text { conjunction with } \\
\text { diverting stream) }\end{array}$} & Native Soil \\
\hline & & & Asphalt \\
\hline & & & Clay \\
\hline & & & Concrete \\
\hline & & & Synthetic Membrane \\
\hline & & & Multilayer Cap \\
\hline & & & Chemical Sealants \\
\hline & In Situ Treatment & Biodegradation & Algal Mats ${ }^{(\omega)}$ \\
\hline & \multirow{8}{*}{$\begin{array}{l}\text { In Situ Treatment (in } \\
\text { conjunction with } \\
\text { either permanent or } \\
\text { temporary stream } \\
\text { diversion) }\end{array}$} & Physical Processes & Solidification (Grouting) \\
\hline & & \multirow[t]{4}{*}{ Chemical Processes } & Oxidation \\
\hline & & & Reduction \\
\hline & & & Hydrolysis \\
\hline & & & Carbon Adsorption \\
\hline & & Biodegradation & Bioreclamation \\
\hline & & \multirow[t]{2}{*}{ Thermal Processes } & In situ Vitrification \\
\hline & & & Thermal Evaporation \\
\hline
\end{tabular}


Table 3.2. (contd)

\begin{tabular}{|c|c|c|c|}
\hline $\begin{array}{l}\text { Remedial Action } \\
\text { Objective }\end{array}$ & $\begin{array}{c}\text { General Response } \\
\text { Actions }\end{array}$ & $\begin{array}{c}\text { Remedial } \\
\text { Technologies }\end{array}$ & $\begin{array}{l}\text { Process } \\
\text { Options }\end{array}$ \\
\hline & \multirow[t]{2}{*}{ Removal } & \multirow[t]{2}{*}{ Excavation } & Mechanical Dredging \\
\hline & & & $\begin{array}{l}\text { Hydraulic Vacuum } \\
\text { Dredging }\end{array}$ \\
\hline & \multirow{16}{*}{$\begin{array}{l}\text { Ex Situ Treatment (in } \\
\text { conjunction with } \\
\text { removal) }\end{array}$} & \multirow{2}{*}{$\begin{array}{l}\text { Solidification/ } \\
\text { Stabilization }\end{array}$} & Macroencapsulation \\
\hline & & & Micorencapsulaton \\
\hline & & \multirow[t]{2}{*}{ Physical Treatment } & $\begin{array}{l}\text { Soil Washing / Solids } \\
\text { Classification }\end{array}$ \\
\hline & & & Dewatering \\
\hline & & \multirow[t]{2}{*}{ Biological Treatment } & $\begin{array}{l}\text { Land } \\
\text { Farming/Composting }\end{array}$ \\
\hline & & & Bioreactors \\
\hline & & \multirow[t]{5}{*}{ Thermal Treatment } & $\begin{array}{l}\text { Low-Temperature } \\
\text { Thermal }\end{array}$ \\
\hline & & & $\begin{array}{l}\text { High-Temperature } \\
\text { Incineration (Haz. Waste } \\
\text { Regulated) }\end{array}$ \\
\hline & & & $\begin{array}{l}\text { Low-Temperature } \\
\text { Incineration }\end{array}$ \\
\hline & & & Pyrolysis \\
\hline & & & Steam Stripping \\
\hline & & \multirow[t]{5}{*}{ Chemical Treatment } & $\begin{array}{l}\text { Solvent Washing / } \\
\text { Extraction }\end{array}$ \\
\hline & & & Molten Solids Processing \\
\hline & & & Dechlorination \\
\hline & & & $\begin{array}{l}\text { Ozone-ultraviolet } \\
\text { exposure }{ }^{(b)}\end{array}$ \\
\hline & & & $\begin{array}{l}\text { Radiolytically induced } \\
\text { decomposition }\end{array}$ \\
\hline & \multirow{3}{*}{$\begin{array}{l}\text { Disposal (in } \\
\text { conjunction with } \\
\text { removal and } \\
\text { pretreatment) }\end{array}$} & \multirow[t]{2}{*}{ Landfill } & Chemical Waste Landfill \\
\hline & & & On-Site Landfill \\
\hline & & Use as fill & Fill Material \\
\hline \multicolumn{4}{|c|}{$\begin{array}{l}\text { Information taken from: } \\
\text { ReOpt (White and Bryant 1993) } \\
\text { (a) Bender and Phillips, Clark Atlanta University, Atlanta, Georgia. (Bender 1993). } \\
\text { (b) Excalibur Enterprises, Inc., New York, New York. (Boeve 1989). }\end{array}$} \\
\hline
\end{tabular}




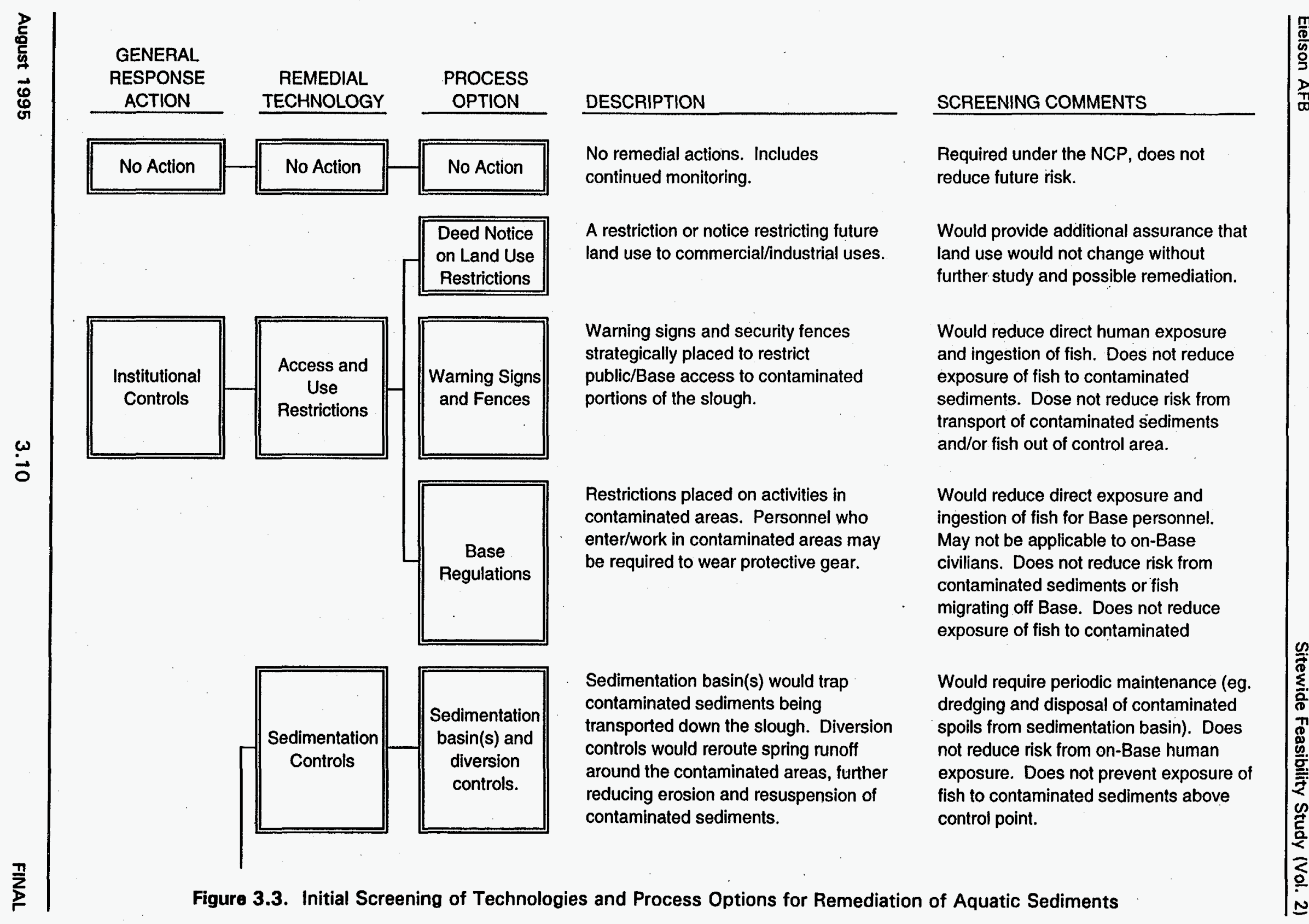

No remedial actions. Includes

A restriction or notice restricting future land use to commercial/industrial uses.

Warning signs and security fences strategically placed to restrict public/Base access to contaminated portions of the slough

Restrictions placed on activities in contaminated areas. Personnel who enter/work in contaminated areas may e required to wear protective gear.

Sedimentation basin(s) would trap contaminated sediments being ported down the slough. controls would reroute spring runof contaminated sediments. 


\section{REMEDIAL PROCESS} TECHNOLOGY OPTION
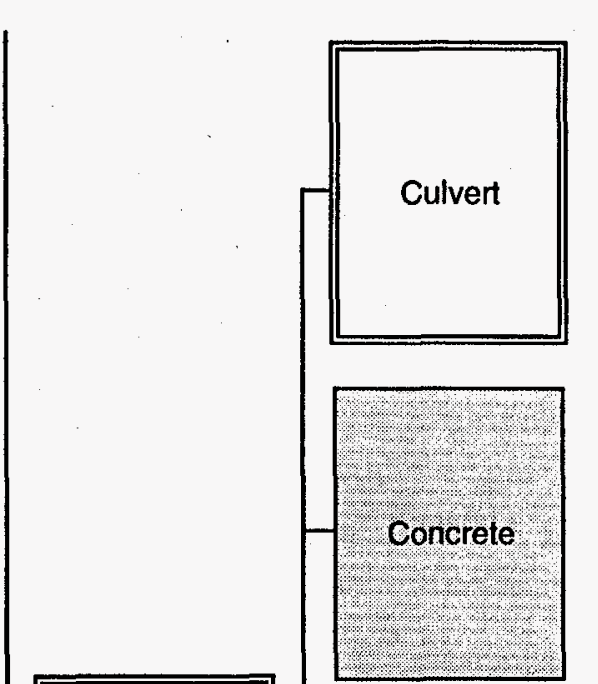

Line Stream Bottom

\section{DESCRIPTION}

Contaminated sediments would be isolated from the ecosystem and human exposure by placing a half culvert in the stream channel and backfilling.

Contaminated sediments would be isolated from the ecosystem and human exposure by lining the stream bottom and banks with concrete.
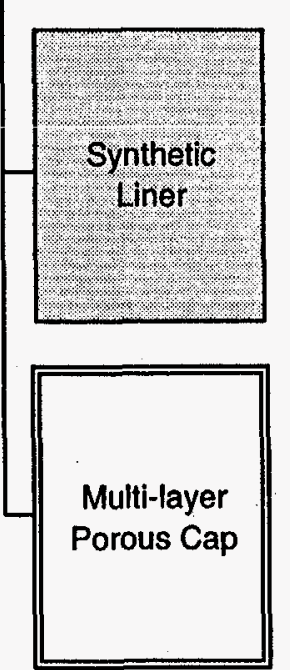

Contaminated sediments would be isolated from the ecosystem and human exposure by lining the stream bottom and banks with a combination of clay, sand, gravel, and cobbles.
Contaminated sediments would be isolated from the ecosystem and human exposure by lining the siream bottom and banks with a synthetic liner.

Figure 3.3. (contd)

\section{SCREENING COMMENTS}

Implementation may be difficult. May require modification of existing channel

(eg. contaminated sediments removed or regraded) and resuspension of sediments. Would have severe impacts on the local ecosystem. Requires maintenance.

Implementation may be difficult in rerouting water and regrading the slough bottom; may have to lower water table to implement. Would have severe impacts on the local ecosystem. Contamination would remain in place. Requires maintenance.

Implementation may be difficult in rerouting water and regrading the slough bottom. May have to lower water table to implement. Would have severe localized impacts on the ecosystem. Contamination would remain in place. Requires maintenance.

Implementation should be relatively straightforward. Contaminated sediments may be resuspended during installation. May require maintenance. Will raise stream bed which may adversely affect its hydraulic flow impacting the ecosystem. 


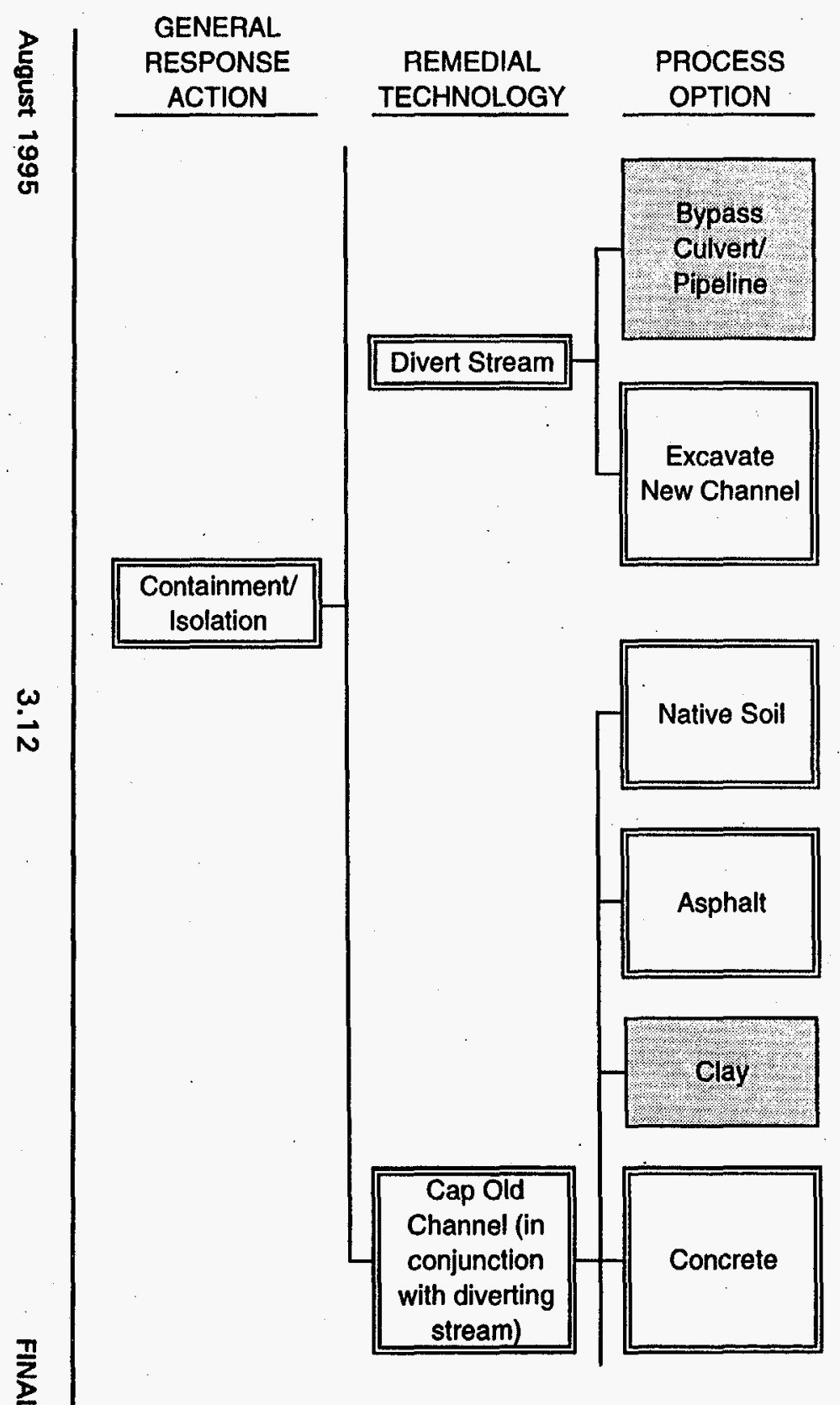

\section{DESCRIPTION}

A culvert/pipeline would be installed to bypass the contaminated portion of the stream to prevent exposure of fish to contaminated sediment and to prevent transport of sediment.

A new stream channel would be excavated to bypass the contaminated portion of the stream to isolate contaminants from fish and eliminate migration of contaminated sediments.

The old stream banks would be scraped into the old channel which would then be backfilled with native soils to isolate contaminants from humans.

The old stream channel would be backfilled with native soils and capped with asphalt or asphaltic concrete to isolate the contaminants from humans.

Backfill old channel and place clay cap over the contaminated area.

The old stream channel would be backfilled with native soils and capped with concrete to isolate the contaminants from humans and fish.

\section{SCREENING COMMENTS}

May not be room to route the bypass. Would essentially destroy the ecosystem corridor between the lower and upper portions of the slough.

May not be room to route the bypass. Would have severe short-term impacts on the local ecosystem.

Easily implemented. Native soils contain high percentages of sand and gravel.

Provides some protection against inadvertent intrusion. Requires maintenance.

Not suitable for highly industrialized areas or areas with severe freeze and thaw cycle.

Provides protection against inadvertent intrusion. Surface must be prepared. Not suitable for area subject to settling. Requires maintenance.

Figure 3.3. (contd) 


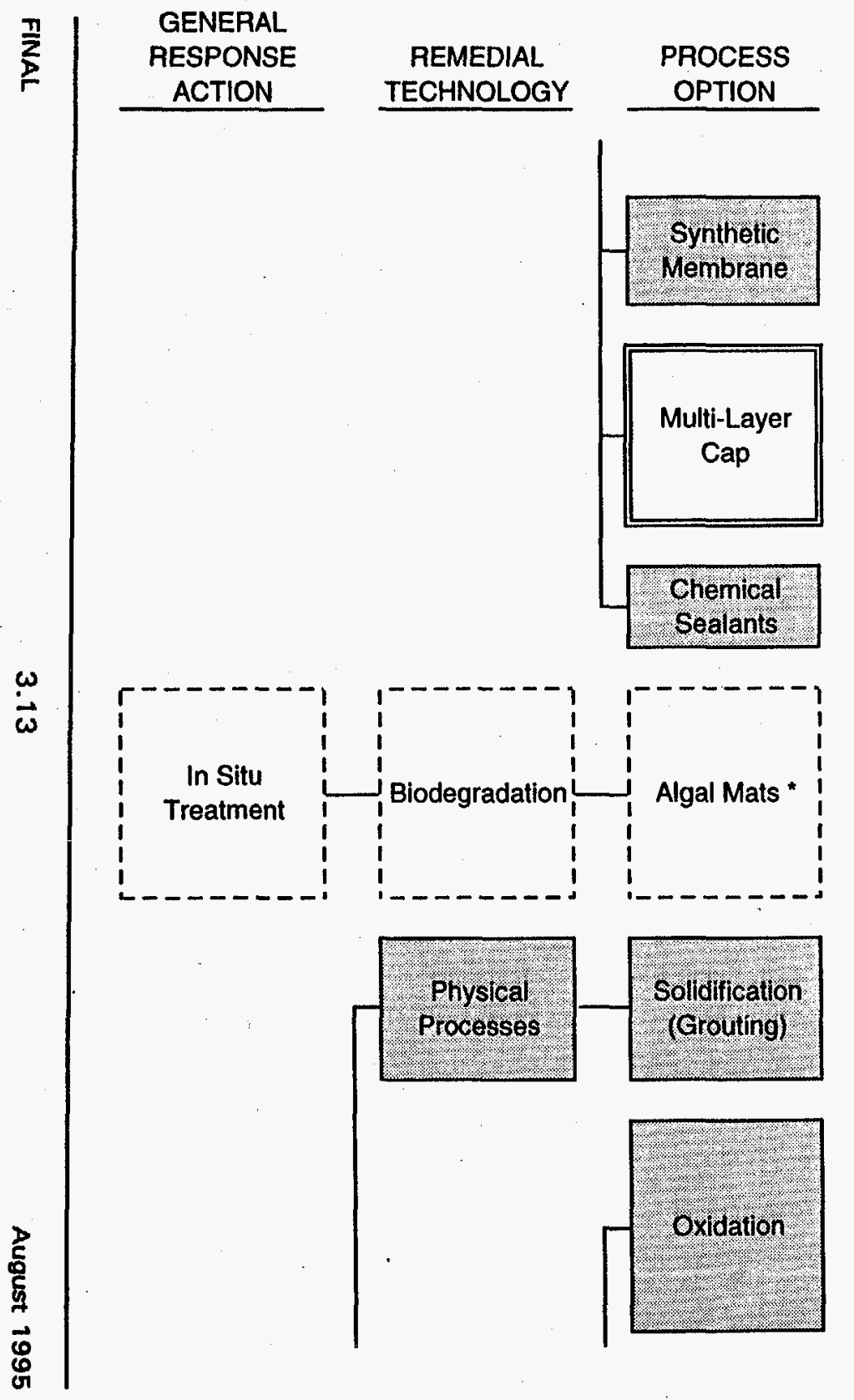

DESCRIPTION

Backfill old channel and install a synthetic liner over the contaminated area.

The old stream channel would be backfilled with native soils and covered with a synthetic liner and a clay and/or soll cap to isolate contaminants from humans.

Spray fixative over the contaminated sediments.

Microbial mats, dominated by cyanobacteria, would be constructed over the contaminated sediments to form a natural autotrophic community harboring the desired cultured microbes for degradation of PCBs.

Contaminated sediments are solidified in place by mixing them or injecting them with some form of solidifying agent (eg, cement, clay, synthetics, etc.)

Oxidizing agents (eg. ozone, hydrogen peroxide) are added to the contaminated soil to raise the oxidation state.

Figure 3.3. (contd)
Difficult to maintain integrity of liner in active industrial area. Requires maintenance.

Will require cold weather engineering.

Requires maintenance.

Difficult to maintain seal coating in active industrial area.

Still in the development stage. Uncertain of the kinetics with PCBs and applicability in an arctic environment. Requires treatability testing.

May be difficult to implement if below water table. Benefit uncertain. Does not prevent direct exposure to humans.

Not a solution in itself; used to assist microbial degradation. Requires addition and control of reagents. May result in contamination of the groundwater by chemical breakdown products. May require lowering of water table. 


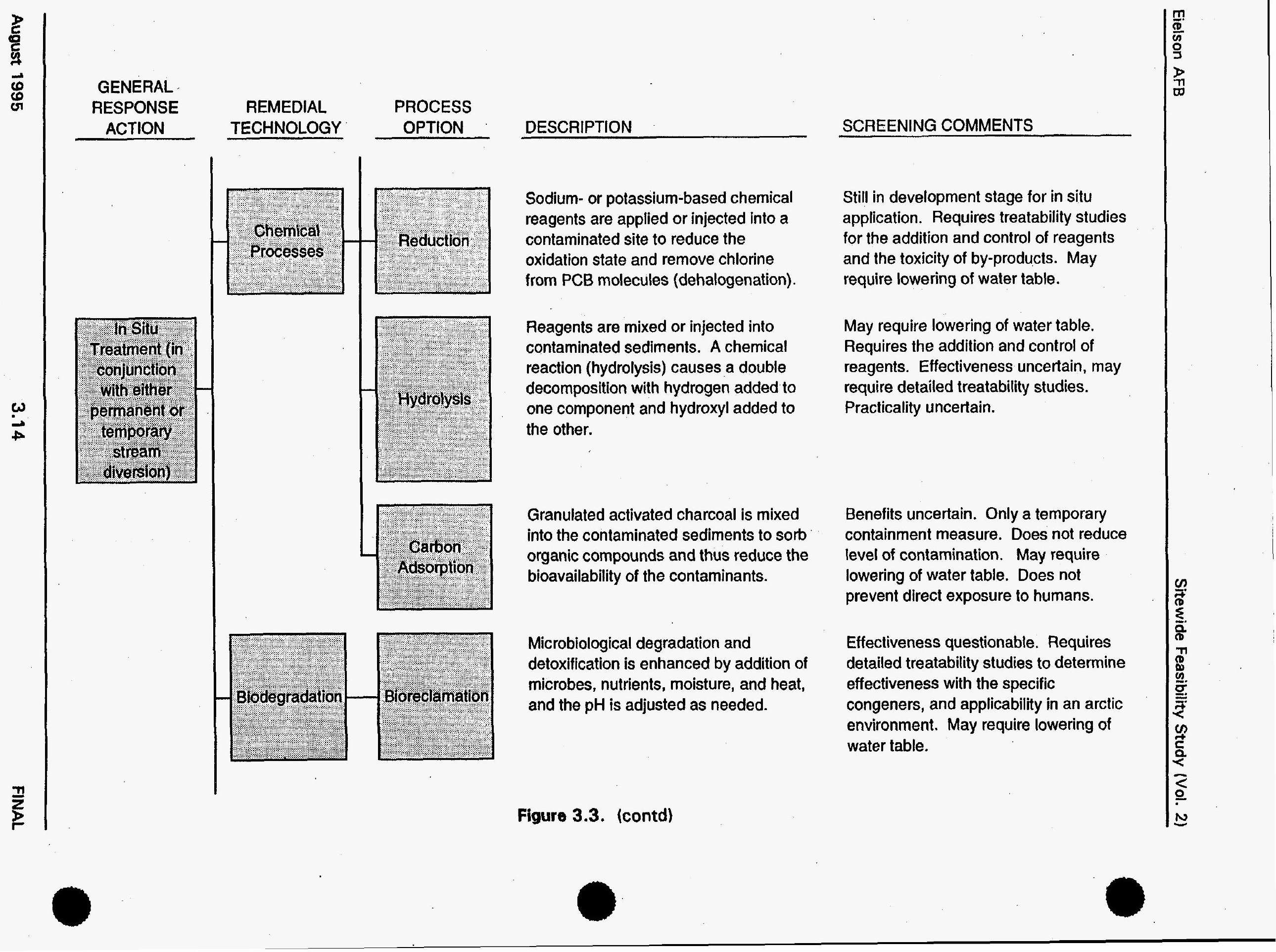




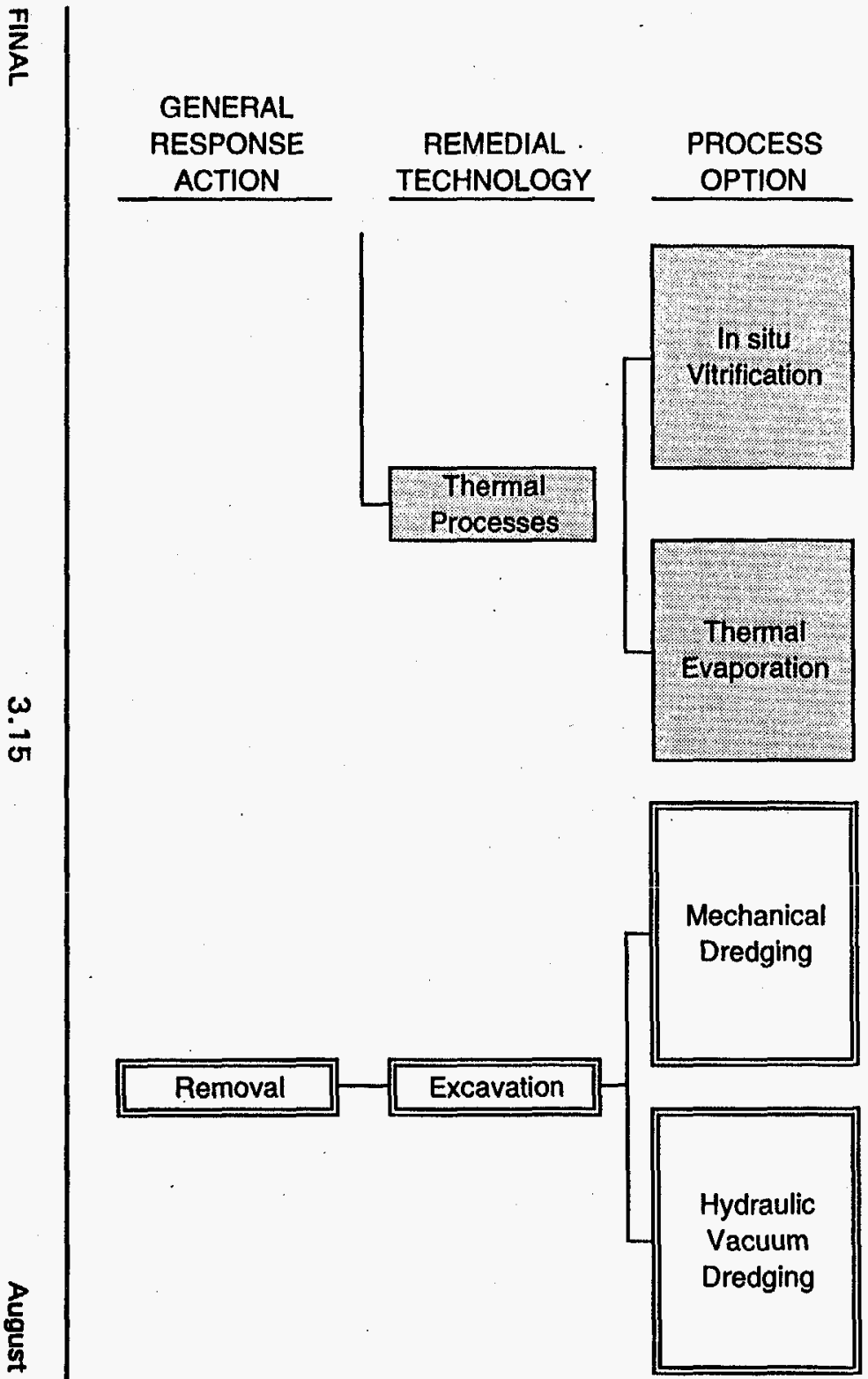

\section{DESCRIPTION}

Contaminated soils are converted in place into durable glass and crystalline product by extreme heat caused by passing an electrical current among four electrodes embedded into the contaminated soils.

Electrodes are placed over surface, or in vertical or horizontal boreholes.

Electromagnetic energy in radio

frequency band is applied to the electrodes to cause rapid heating of the soil by molecular excitation.

Contaminated sediments are mechanically removed from the stream bottom via clam shell, backhoe, or other mechanism.

Contaminated sediments are hydraulically vacuumed from the stream bottom.

Figure 3.3. (contd)

\section{SCREENING COMMENTS}

Experimental process option; not proven in saturated sediments. Probably not cost effective for long narrow sources of low concentrations. Can not be implemented without lowering water table.

Experimental process option. Probably not cost effective for long narrow sources of low concentrations.

Practicality uncertain; may require lowering of water table.

Suitable for small areas. Difficult through moving/standing water or saturated sediments. Difficult to control accuracy of excavation. Will cause

substantial resuspension of sediments. Would have severe short-term impacts on the local ecosystem.

Suitable for small areas. Accuracy of excavation is good. Causes little resuspension of sediments. Produces large volumes of waste water. Can leave coarse sediments behind. Would have some short term impacts on the local ecosystem. 


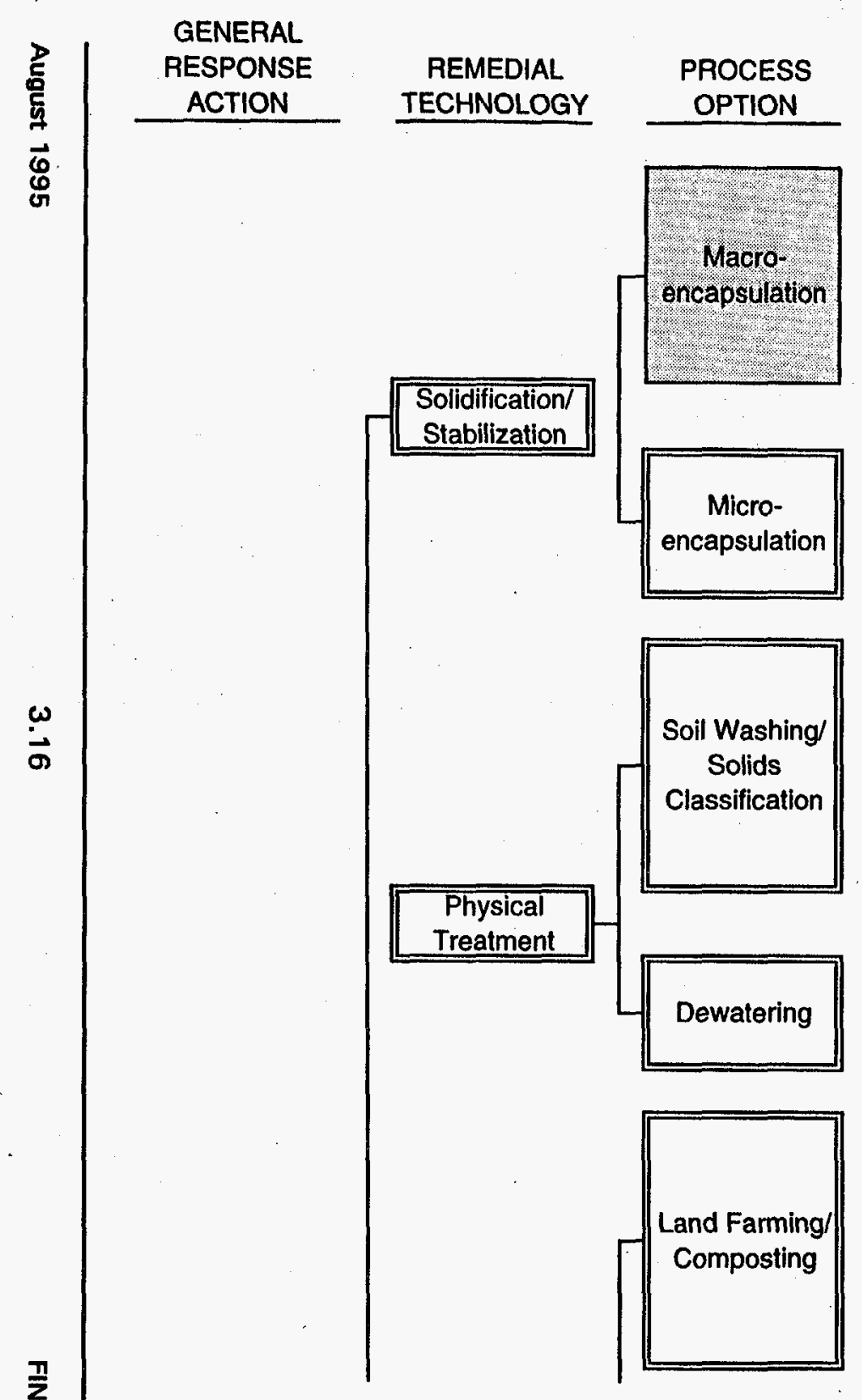

Contaminated waste is placed in an inert jacket or container (welded polyethylene, fiberglass, spray on resins)

Contaminated sediments are mixed or incorporated into a

solidification/stabilizing matrix such as cement, polymers, or asphalt.

Uses screens and cyclone separators to segregate contaminated sediments by size, thus reducing the volume, and preparing a uniform composite for treatment or disposal. May be washed with a detergent to remove contaminant from the coarse fraction.

Removes residual water from saturated sediments, either by drying or use of an absorbent agent.

Excavated sediments are spread in layers or placed in piles or cells. Microorganisms (white rot fungus) are added with soil amendments (wood chips) and nutrients to degrade the PCBs.

Figure 3.3. (contd)
Used when waste materials are difficult to stabilize, are extremely hazardous, or reactive. For stable on-site storage and stable waste containers for land disposal. Not necessary for Garrison Slough contaminants.

Used as a pretreatment prior to on-site storage or land disposal. Benefits uncertain. Increases volume.

Reduces volume of contaminated sediments. Generates liquid wastes, and potentially contaminated residuals. Used as a pretreatment.

Used as a pretreatment prior to further treatment or disposal.

Should be effective over several summers. Treatment and isolation facilities already exists on-site. A low cost large volume treatment option. No continued operator attendance required. Effectiveness in an arctic environment unproven. 
GENERAL

RESPONSE

REMEDIAL

PROCESS TECHNOLOGY OPTION

DESCRIPTION

SCREENING COMMENTS

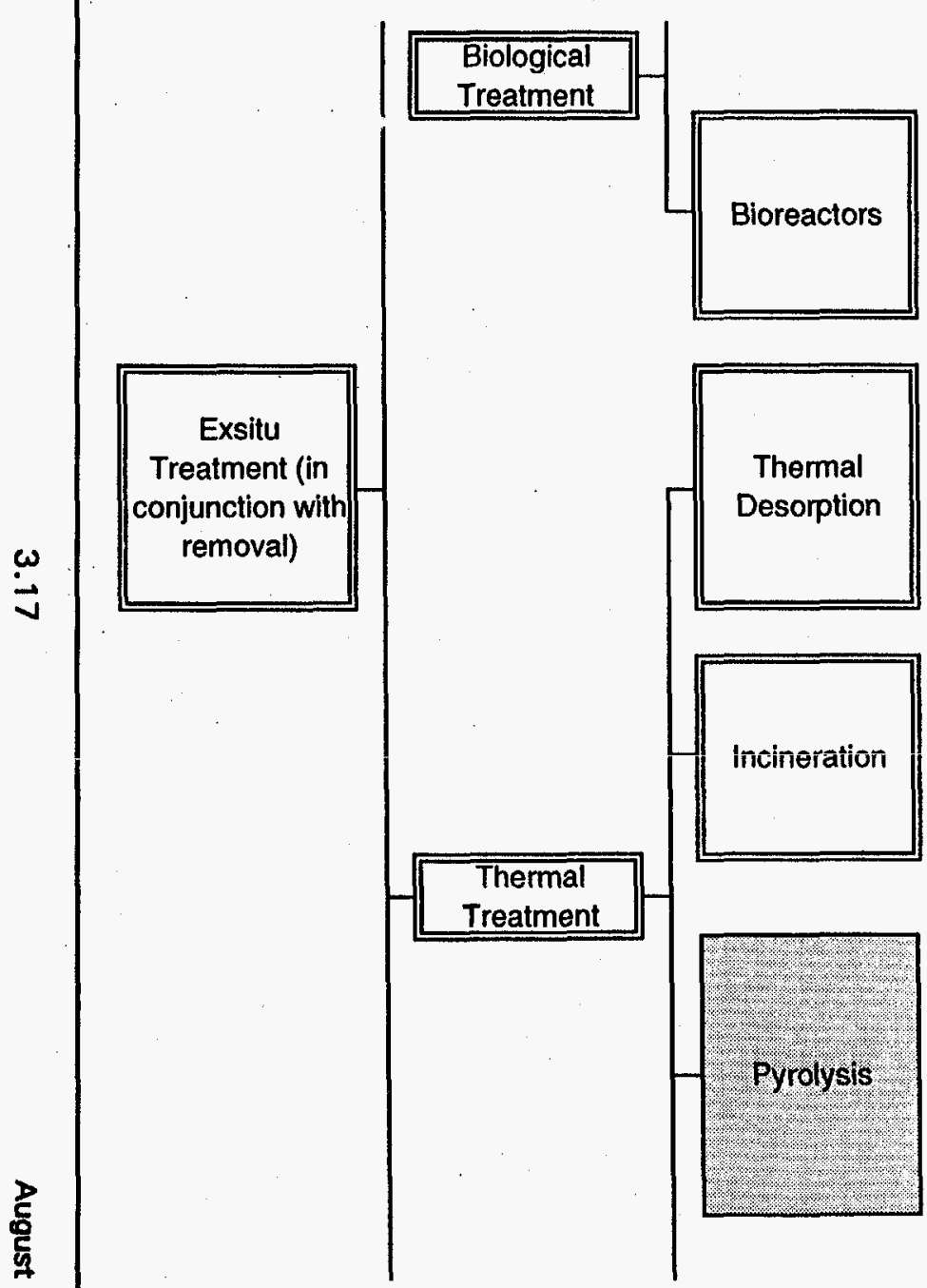

Excavated sediments are placed in controlled biocells for rapid biodegradation.

conducted in small batches. Can be

effective only over extended periods.

Requires operator attendance. A high

cost treatment option.

Proven technology. Can be effective.

Contaminated sediments are heated in a low temperature furnace. The organics are vaporized and the off-gas is collected (eg. on activated carbon) for disposal or further treatment. small volumes (eg. $<5000 \mathrm{cu}$. yd.). May be practical with rental/lease equipment, if available. Requires treatment/disposal of off-gass and residuals.

\section{Contaminated sediment is burned in a} TSCA approved incinerator.

Contaminants are permanently destroyed.

Very effective (99.9999\%). Permitted hazardous waste incinerator unavailable in Alaska. Cosi and permititing of on-site incinerator very expensive. Transport to out-of-state incinerator very expensive.

Organic wastes are exposed to high temperature in the absence of sufficient oxygen for complete combustion.

Volatile organics are produced that are combusted in an afterburner

Well-developed commercially available technology. Acceptable for PCBs in conjunction with TSCA approved incinerator. Equipment is large and too expensive for on-site treatment.

Permitting the afterburner section may pose a problem.

Figure 3.3. (contd) 


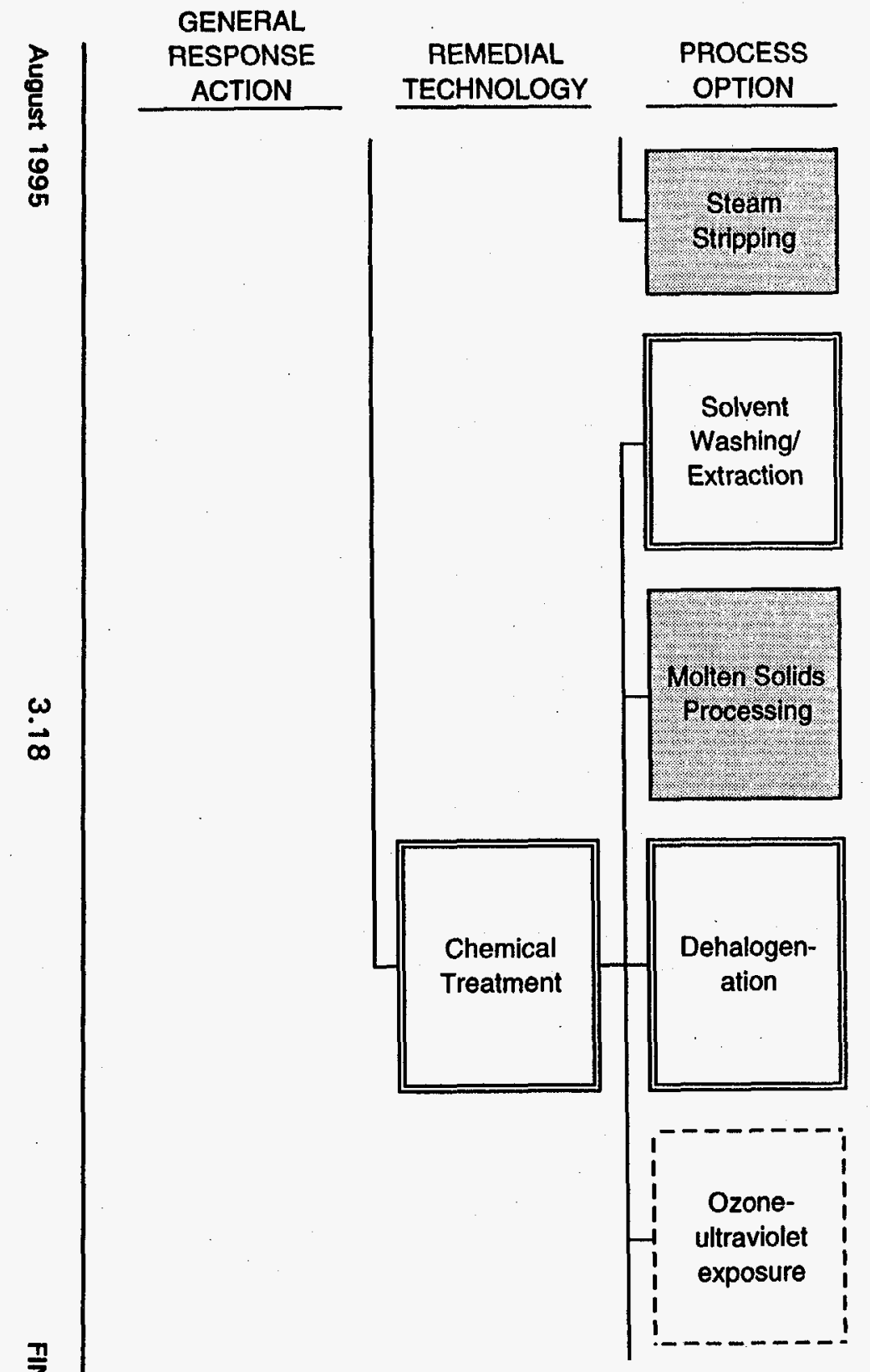

DESCRIPTION

Volatile materials are heated and removed with steam.

Uses a liquid solvent or supercritical fluid to dissolve contaminants from contaminated soils.

Uses high temperatures to destroy the organic constituents of a waste. This includes molten glass processes, slagging incineration, incineration in molten salt, and incineration by plasma systems.

Contaminated soils are placed in reactor with reagents (potassium polyethylene glycol [KPEG]), mixed, and heated. Reaction breaks carbonchlorine bonds. Soil and reagent are separated and the soil neutralized.

The Ozone, Ultraviolet, Ultrasonics, and Uitrapure Water (OUUU) process** uses ultrapure water to remove contaminants from sediment, then treats the aqueous solution to convert the contaminants to $\mathrm{CO} 2, \mathrm{H} 2 \mathrm{O}$, and salts.

\section{SCREENING COMMENTS}

PCBs not volatile at practical steam temperatures. Not effective. Residuals and effluents must be disposed or further treated.

Demonstrated to remove PCBs. Cleans and segregates waste into clean coarse fractions suitable for fill, and fine grained residuals for further treatment/disposal.

Solvent waste must also be treated.

Requires treatability studies.

Technologies are primarily in development stage. Requires detailed treatability studies. Not necessary for

Garrison Slough contaminants.

Potentially very effective. Utilizes specialized equipment to reach temperatures of $\sim 150^{\wedge} \mathrm{C}$. Only one vendor available. Treatability studies required. Generates reagent waste, other liquid wastes, and potentially contaminated residuals.

Innovative technology. Still in the development stage for large volumes.

Figure 3.3. (contd) 


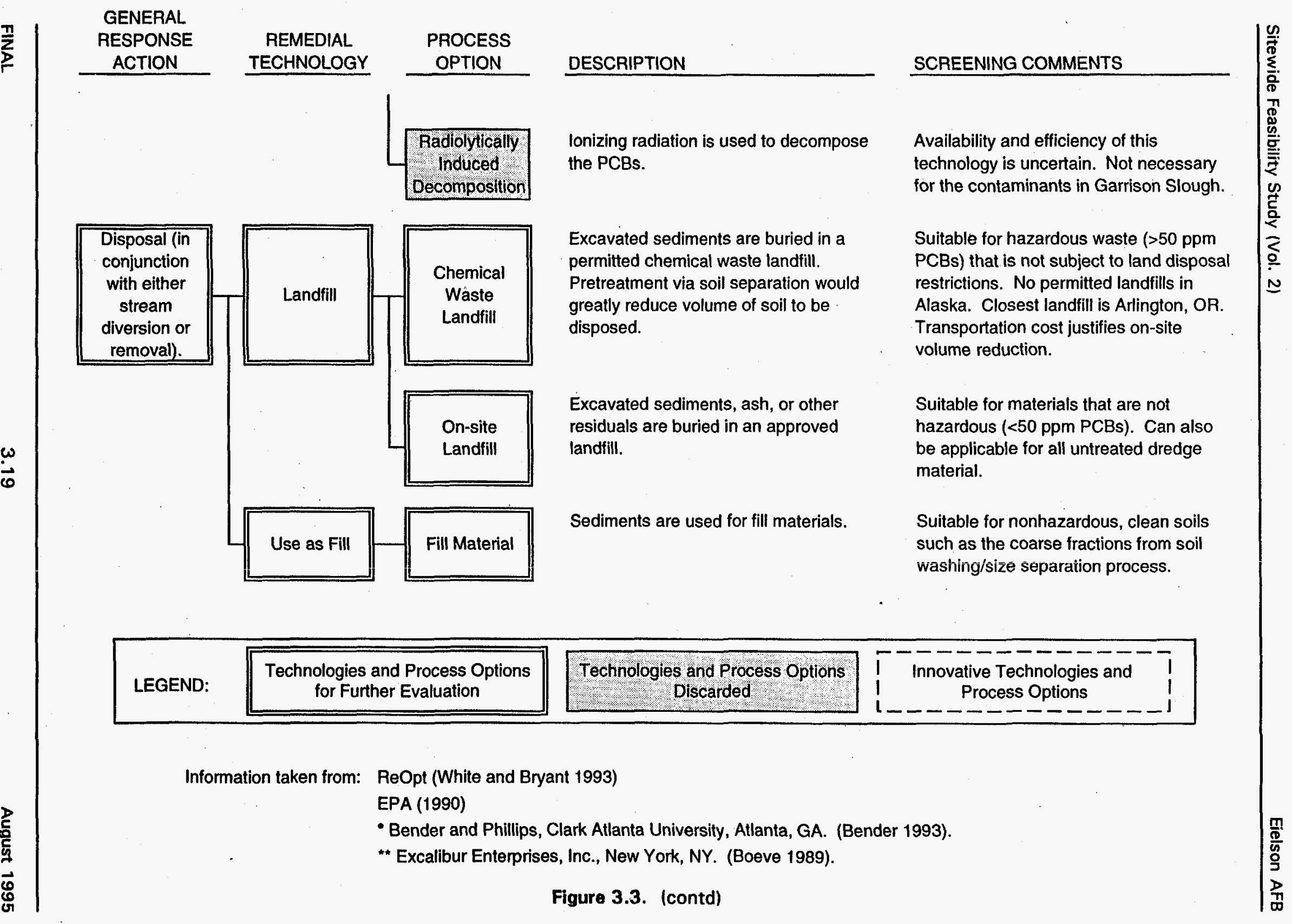




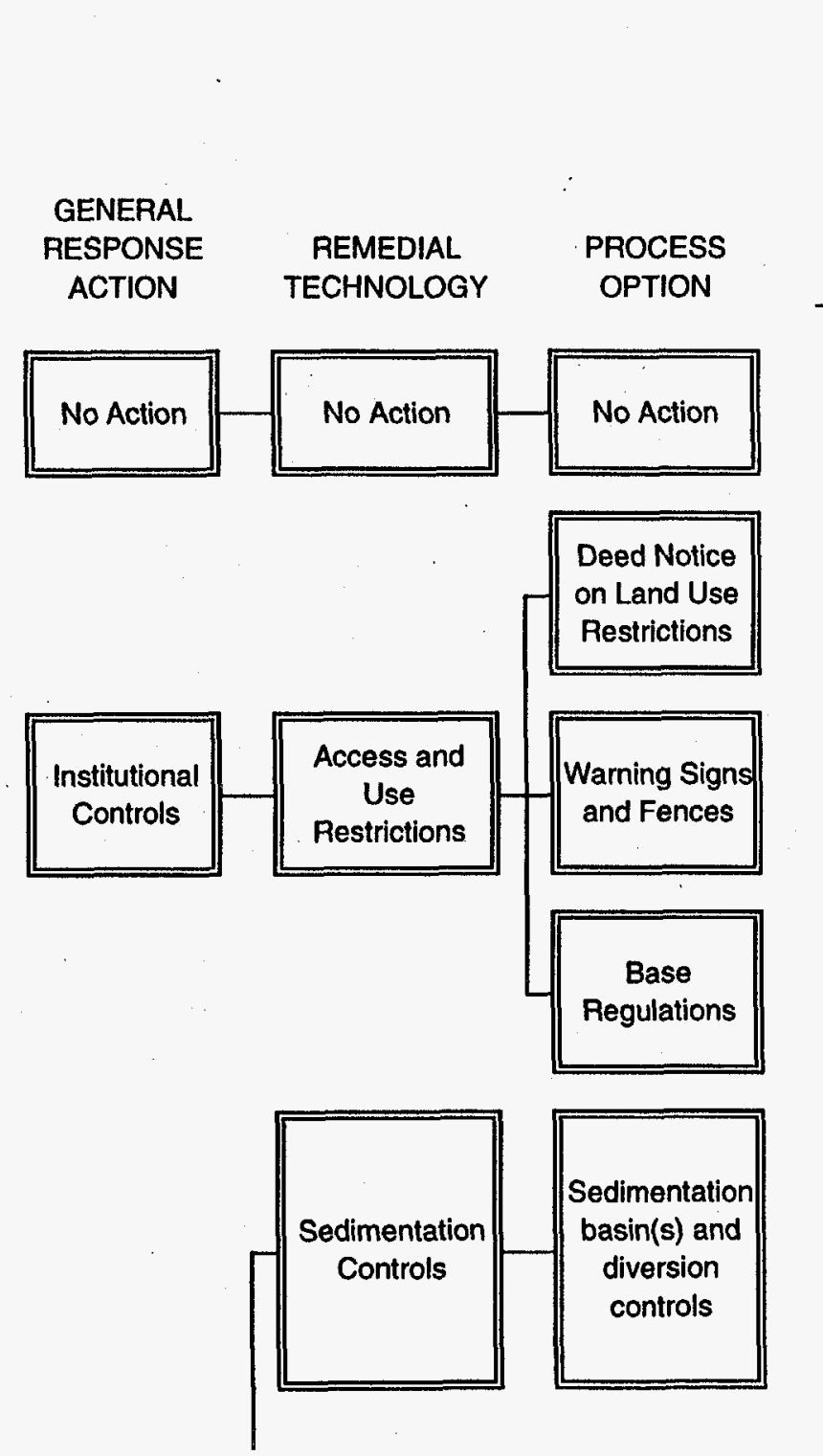

\section{EFFECTIVENESS}

Does not achieve remedial action objectives.

Effectiveness depends on continued future

implementation. Does not reduce contamination.

Effective in reducing direct personal exposure and ingestion of fish. Does not reduce contamination.

Effective in reducing direct personal exposure and ingestion of fish. Does not reduce contamination.

Can be effective in reducing the spread of contaminated sediments, thereby limiting areal extent of exposure to water column organisms. May not significantly affect bioaccumulation.

\section{IMPLEMENTABILITY}

Easily implemented.

Regulatory and public

acceptability uncertain.

Some legal requirements

and authority issues to

overcome.

Easily implemented.

Relatively easy to implement. Some

authority/approval issues to overcome.

Can be implemented. May impact the local stream

ecosystem. Only

temporary. Requires

maintenance.

\section{COST}

No capital.

Low O \& M

(monitoring).

No capital.

Low O \& M

(monitoring).

Very low capital.

Low O \& $M$

(maintenance

and monitoring).

No capital.

Low O \& M

(monitoring).

Low capital.

Moderate O \& M

(maintenance

and monitoring).

Figure 3.4. Evaluation of Process Options for Remediation of Aquatic Sediments 
GENERAL

RESPONSE

ACTION

REMEDIAL
TECHNOLOGY

PROCESS

OPTION

\section{EFFECTIVENESS}

IMPLEMENTABILITY

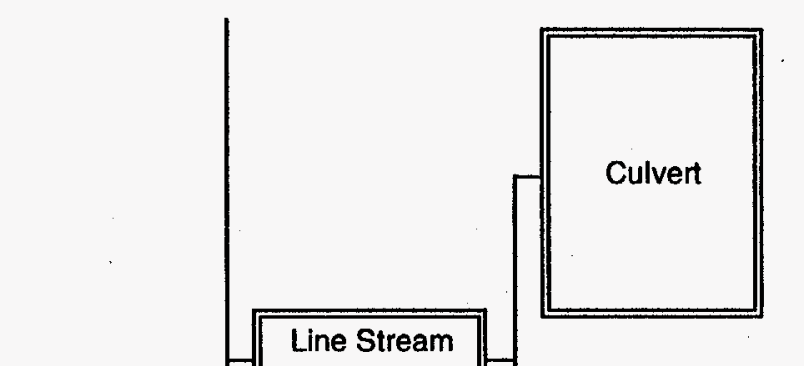

Effective in reducing direct personal exposure and ingestion of fish. Does not reduce contamination.

Can be implemented. May

Moderate capital. require regrading of stream channel and resulting

resuspension of

contaminated sediments.

Would have severe impacts

on the local ecosystem.

\section{Can be implemented.}

Requires maintenance.

Moderate capital. direct exposure to water column organisms. Does not prevent exposure to

PCBs partitioning into the

interstitial and surface

water. Long-term integrity

uncertain, may be subject to

bioturbation.

Effective in reducing

migration of contaminated

sediments, and

bioaccumulation in fish.

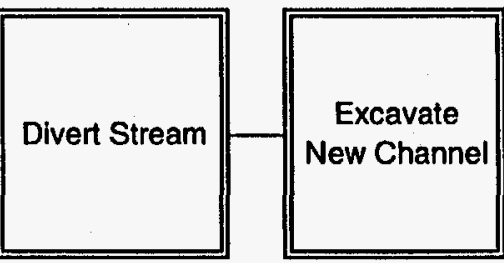 \\ May be difficult to have severe short term impacts on the local} implement near the CE maintenance shop, where space is limited. Would

(maintenance).

Figure 3.4. (contd) 


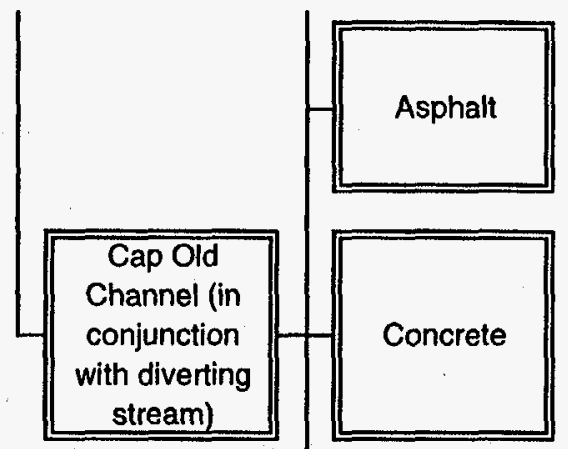

Effective in isolating contaminants from humans.

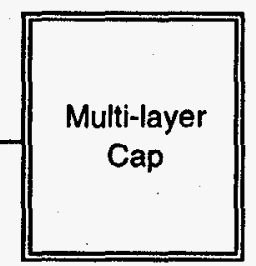

\section{Effective in isolating} contaminants from humans and fish. Provides

protection against migration of contaminants to groundwater.

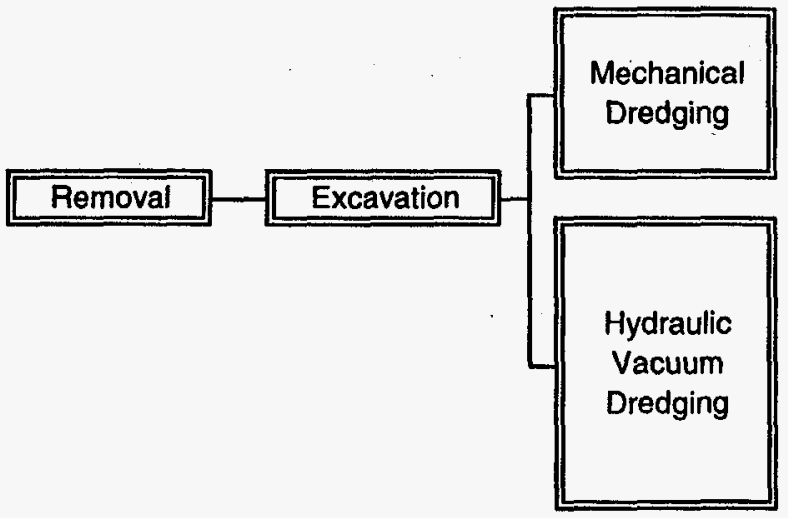

Very effective. May cause resuspension and

downstream transport of contaminated sediments.

Very effective.

Figure 3.4. (contd)
Relatively easy to

implement.

Surface must be stabilized and prepared. May require dewatering of aquifer during implementation.

Can be implemented.

Requires cold weather

engineering.

Somewhat difficult to implement through moving water; also difficult handling saturated sediments.

Can be implemented. Provides better control over depth of dredging.

Resuspension of sediments should be minor. Produces large quantities of water to treat.
Moderate capital cost. Low to moderate $O \& M$

(maintenance).

Moderate capital. Low O \& M

(maintenance).

High capital. Low O \& M

(maintenance).

Low Capital.

Low to moderate $O \& M$.

Moderate capital. Moderate O\& M. 


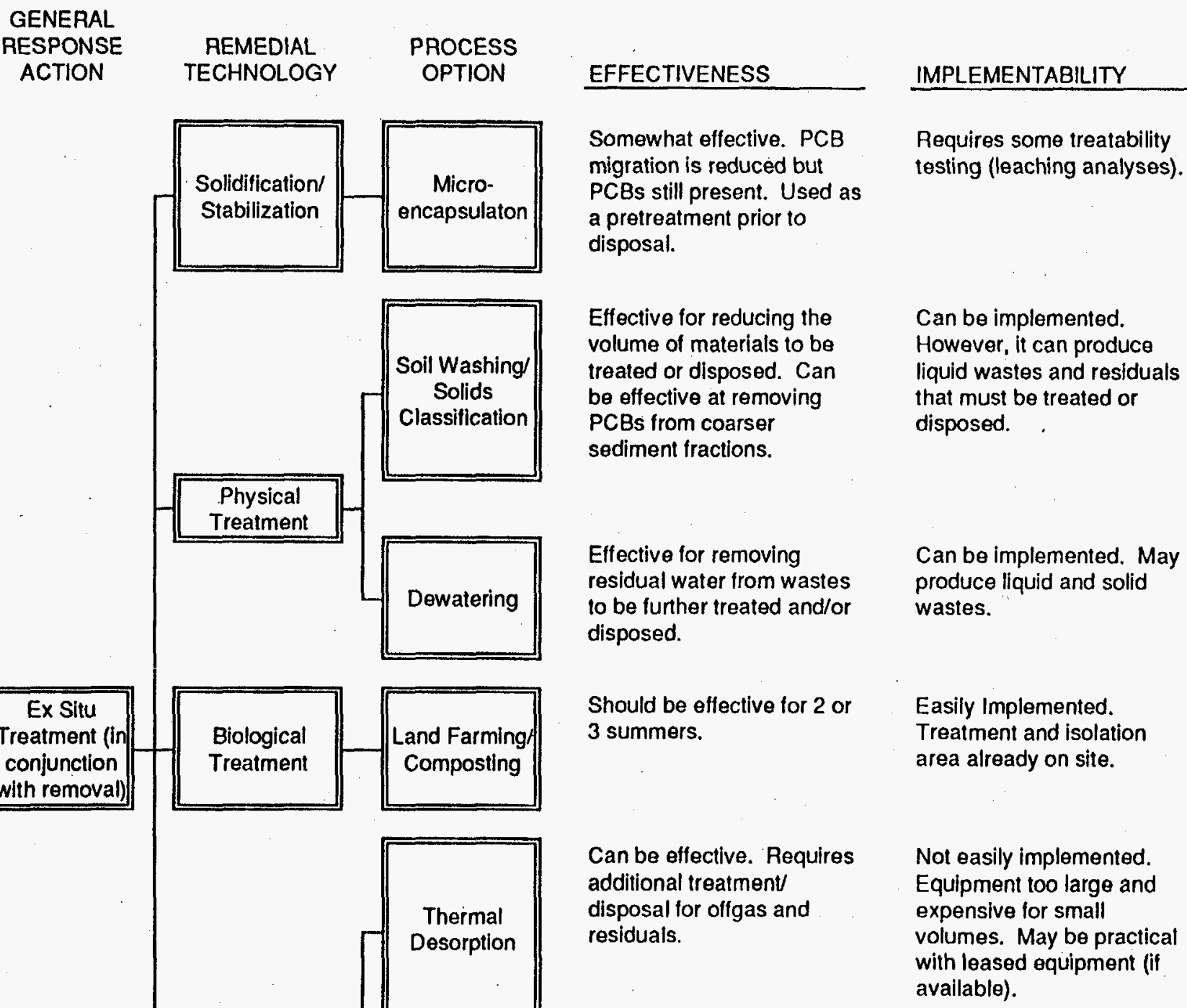

EFFECTIVENESS

Somewhat effective. PCB migration is reduced but PCBs still present. Used as a pretreatment prior to disposal.

Effective for reducing the volume of materials to be treated or disposed. Can

be effective at removing

PCBs from coarser

sediment fractions.

Physical

Soil Washing

Solids

Classification

Effective for removing

residual water from wastes

to be further treated and/or

disposed.

Should be effective for 2 or 3 summers.

Requires some treatability testing (leaching analyses).

Can be implemented. However, it can produce liquid wastes and residuals

that must be treated or

disposed.

Can be implemented. May produce liquid and solid wastes.

Easily Implemented. Treatment and isolation area already on site.

Not easily implemented. Equipment too large and expensive for small

Can be effective. Requires additional treatment disposal for offgas and residuals.

volumes. May be practical with leased equipment (if available).

$\cos T$

Moderate capital. Moderate O\& M.
Low to moderate capital.

Low to moderate $O \& M$.

Moderate capital. Moderate O \& M.

Moderate to high

capital.

Moderate O \& M.

Figure 3.4. (contd) 

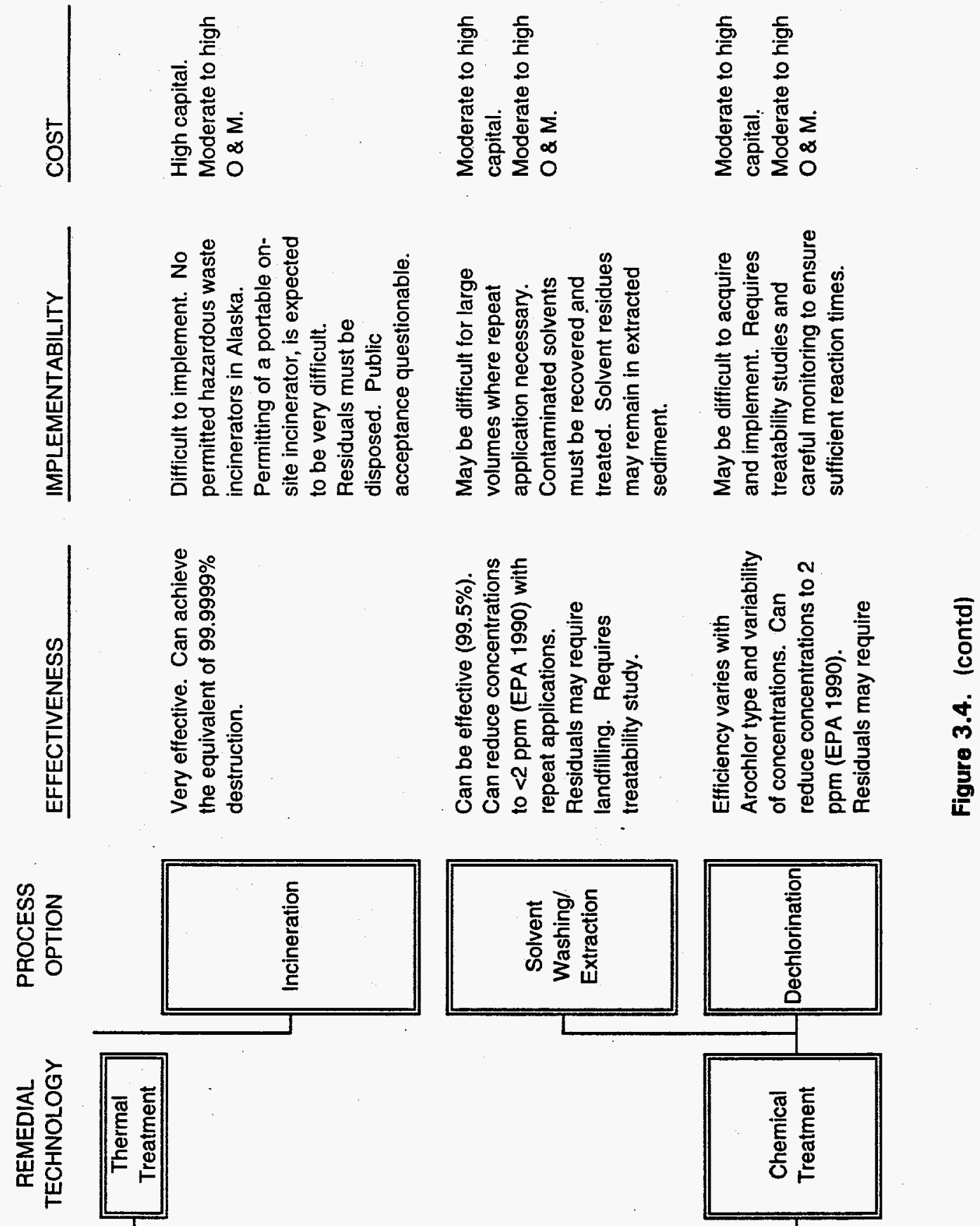

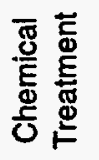

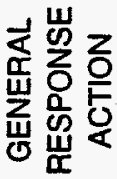


GENERAL RESPONSE

REMEDIAL

TECHNOLOGY

\begin{tabular}{|c|}
\hline Disposal (in \\
conjunction \\
with either \\
stream \\
diversion or \\
removal) \\
\hline
\end{tabular}

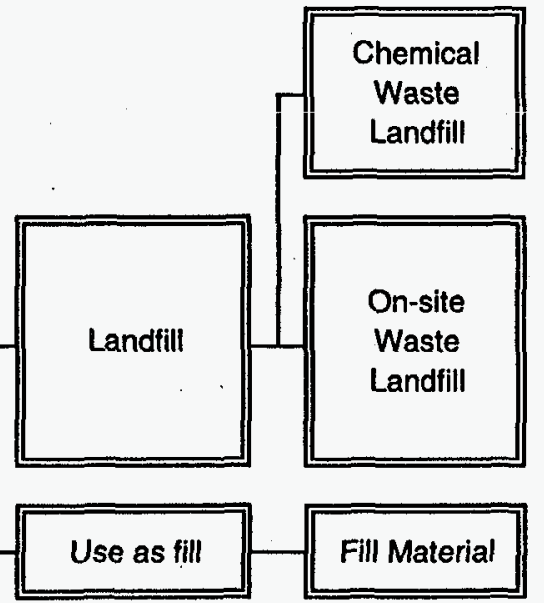

EFFECTIVENESS

Effective.

Effective for solids that are not subject to land disposal restrictions.

Effective.

Figure 3.4. (contd)
Difficult to implement since closest permitted chemical waste landill is in Arlington, OR.

Can be implemented if $\mathrm{PCB}$ concentrations are below 50 ppm. Can be acceptable for all untreated dredge material.

Can be implemented for non-hazardous materials.

\section{Cost}

High capital. Low O \& M

(maintenance)

Low Capital. Low O \& M.

Low Capital. Low O \& M. 


\subsection{PRELIMINARY DEVELOPMENT AND EVALUATION OF ALTERNATIVES}

The purpose of this section is to assemble and screen a focused set of potentially applicable alternatives from the technologies and process options identified in Section 3.0. The alternatives are assembled by identifying appropriate technologies for each medium and then selecting a process option that is representative of those technologies. Each alternative represents a separate level of control and time frame for risk reduction.

\subsection{PROCESS FOR THE DEVELOPMENT OF ALTERNATIVES}

Remedial action alternatives are assembled by identifying appropriate technologies for each affected medium, and then selecting a representative process option for alternative development. The primary objective of the alternatives development process is to identify remedial alternatives capable of achieving the RAOs identified in Section 2.0. As required by the NCP, the range of alternatives to be developed for source control actions include:

- a no action alternative

- one or more alternatives that involve little or no treatment, but protect human health and the environment through

- institutional controls, and

- the use of engineering controls (containment)

- one or more treatment alternatives that reduce the toxicity, mobility, or volume of contaminants, aimed at

- the principal threat posed by the site, and

- eliminating or minimizing, to the degree possible, the need for long-term site management.

Each of the assembled alternatives presents a different level of control and risk reduction. After the alternatives are assembled, they are evaluated on the basis of effectiveness, implementability, and relative cost to identify the final list of alternatives for detailed evaluation.

The governing premise in developing a focused set of remedial alternatives for Garrison Slough was to protect human health by reducing the potential for ingestion of PCB-contaminated fish. The secondary, longer term, focus was to reduce the source of PCBs available for bioaccumulation in the fish, by either isolating, or removing and treating, or disposing of the contaminated sediments.

In keeping with the focused nature of this FS, a maximum of five alternatives (including the no action and limited action [institutional controll alternatives) will be retained for detailed evaluation. While several technologies or process options may remain viable for a specific general remedial action alternative, only one technology/process option is selected to represent that alternative.

The alternatives are presented as comprehensive source control actions (for example, fish and sediment remedial actions combined into a single alternative). However, the alternatives were assembled in such a manner that individual components of the alternatives can be mixed and matched to increase the effectiveness of a single alternative. This modular approach allows the Air Force to implement remedial actions in several phases, adding technologies as necessary to achieve the RAOs. 


\subsection{GENERAL REMEDIAL ACTION ALTERNATIVES}

The technologies and process options that were retained from the screening in Section 3.0 have been assembled into a set of general remedial action alternatives (Table 4.1). This range of alternatives includes lower cost and less protective options and high cost options that increase protection by accomplishing the remedial action objectives within a shorter time frame and provide a more permanent reduction in risk. A list of the general remedial action alternatives include:

- No Action

- Limited Action

- In Situ Capping

- Divert Stream

- Dredge and Dispose

- Dredge and Treat

A description of these general remedial action alternatives and the process options retained in them follows.

\subsubsection{No Action}

The No Action alternative is self-explanatory. It requires that no action be taken with regard to either the fish population or the sediment concentrations. This alternative does not actively seek to reduce the risk from contaminated fish, but relies on natural attenuation/degradation. Ongoing environmental monitoring of fish, sediment, and surface water concentrations would continue.

\subsubsection{Limited Action}

The Limited Action alternative is aimed at providing a near immediate reduction in human exposure to PCBs, primarily by cutting short the food chain pathway. This alternative uses institutional controls to restrict the amount of fish caught for food, and engineering controls to restrict the migration of fish into contaminated portions of the slough.

Although access and use restrictions (deed notices, warning signs and fences, and base restrictions) also passed the screening process, they have not been included in this alternative, as they would have less direct effect and be more difficult to implement. Restricting access to the more highly contaminated portion of the slough would prevent direct human exposure and the harvesting of fish in that region. However, direct human exposure by itself, does not pose an unacceptable risk (USAF 1995b), and the issuance of a Fishing Advisory and Restrictions would be more effective because they cover a larger area.

Fishing Advisory/Restrictions: The Fishing Advisory/Restrictions would be promulgated by the Alaska State Department of Fish and Game. An advisory would be issued stating the ingestion of more than 1 meal ( $\geq 300 \mathrm{~g}$ ) of fish per year from Garrison Slough may pose an unacceptable health risk ( $>10^{-8}$ excess cancers) and should be avoided. This advisory would help to reduce the health risk to the population, but does not prevent exposure to contaminated fish. A further precaution would be to designate Garrison Slough as a catch-and-release-only area. This process would further reduce the potential for ingestion of contaminated fish. 
Table 4.1. Assemblage of Alternatives

\begin{tabular}{|c|c|c|c|c|c|c|c|c|c|}
\hline \multicolumn{4}{|c|}{. } & \multirow{2}{*}{$\begin{array}{c}\text { NO } \\
\text { ACTION }\end{array}$} & \multirow{2}{*}{$\begin{array}{l}\text { LIMITED } \\
\text { ACTION }\end{array}$} & \multicolumn{2}{|c|}{ CONTAINMENT } & \multirow{3}{*}{$\begin{array}{c}\text { REMOVE } \\
\text { AND } \\
\text { DISPOSE }\end{array}$} & \multirow{3}{*}{$\begin{array}{l}\text { REMOVE } \\
\text { AND } \\
\text { TREAT }\end{array}$} \\
\hline \multicolumn{4}{|c|}{ GENERAL RESPONSE ACTION } & & & In Situ & Stream & & \\
\hline Medium & $\begin{array}{c}\text { Technology } \\
\text { Type }\end{array}$ & Process Option & $\begin{array}{l}\text { Area or } \\
\text { Volume }\end{array}$ & & & & & & \\
\hline \multirow[t]{5}{*}{ Fish } & No Action & $\begin{array}{l}\text { No Action } \\
\text { (Monitoring) }\end{array}$ & $\begin{array}{l}\text { Lower } \\
\text { Garrison }\end{array}$ & $X$ & & & & & \\
\hline & \begin{tabular}{|l} 
Access \\
Restrictions
\end{tabular} & \begin{tabular}{|l} 
Access \\
Restrictions
\end{tabular} & $\begin{array}{l}\text { Lower } \\
\text { Garrison }\end{array}$ & & $x$ & $x$ & $x$ & $x$ & $x$ \\
\hline & $\begin{array}{l}\text { Fishing } \\
\text { Advisory }\end{array}$ & $\begin{array}{l}\text { Fishing Advisory } \\
\text { i Restrictions }\end{array}$ & $\begin{array}{l}\text { Lower } \\
\text { Garrison }\end{array}$ & & $\mathrm{x}$ & $x$ & $\mathrm{x}$ & $\mathrm{X}$ & $\mathrm{X}$ \\
\hline & $\begin{array}{l}\text { Physical Fish } \\
\text { Controls }\end{array}$ & Fish Screens & $\begin{array}{l}\text { Lower } \\
\text { Garrison }\end{array}$ & & $x$ & $x$ & $x$ & $x$ & $x$ \\
\hline & & $\begin{array}{l}\text { Fish Control } \\
\text { Dam }\end{array}$ & $\begin{array}{l}\text { Lower } \\
\text { Garrison }\end{array}$ & & 8 & $x$ & $x$ & $x$ & $x$ \\
\hline \multirow[t]{15}{*}{ Sediment } & No Action & $\begin{array}{l}\text { No Action } \\
\text { (Monitoring) }\end{array}$ & $\begin{array}{l}\text { Lower } \\
\text { Garrison }\end{array}$ & $\mathrm{X}$ & & & & & \\
\hline & \multirow[t]{3}{*}{$\begin{array}{l}\text { Access \& Use } \\
\text { Restrictions. }\end{array}$} & $\begin{array}{l}\text { Deed Notice on } \\
\text { Land Use }\end{array}$ & $\begin{array}{l}\text { Lower } \\
\text { Garrison }\end{array}$ & & $x$ & & & & \\
\hline & & $\begin{array}{l}\text { Warning Signs } \\
\text { andlor Fences }\end{array}$ & $\begin{array}{l}\text { Lower } \\
\text { Garrison }\end{array}$ & & $\mathrm{x}$ & & & & \\
\hline & & \begin{tabular}{|l} 
Base \\
Regulations
\end{tabular} & $\begin{array}{l}\text { Lower } \\
\text { Garrison }\end{array}$ & & $x$ & & & & \\
\hline & $\begin{array}{l}\text { Sedimentation } \\
\text { Controls }\end{array}$ & $\begin{array}{l}\text { Sed. Basin(s) I } \\
\text { Diversion Contrl }\end{array}$ & $\begin{array}{l}\text { Lower } \\
\text { Garrison }\end{array}$ & & $x$ & $\mathrm{x}$ & $x$ & $\mathrm{X}$ & $\mathrm{X}$ \\
\hline & \multirow[t]{2}{*}{$\begin{array}{l}\text { Line Stream } \\
\text { Botlom }\end{array}$} & Culvent & $300 \mathrm{~m}(80 \%$ & & & $x$ & & & \\
\hline & & Multi-Layer Cap & $\begin{array}{l}300 \mathrm{~m}(80 \% \\
\text { PCBs) }\end{array}$ & & & $\mathrm{X}$ & & & \\
\hline & Divert Stream & $\begin{array}{l}\text { Excavate New } \\
\text { Channel }\end{array}$ & $\begin{array}{l}300 \mathrm{~m}(80 \% \\
\text { PCBs) }\end{array}$ & & & & $x$ & & \\
\hline & \multirow[t]{4}{*}{\begin{tabular}{l|} 
Cap Old \\
Channel \\
(w/stream div)
\end{tabular}} & Native Soil & $\int_{\mathrm{PCBs})}^{300 \mathrm{~m}}(80 \%$ & & & & $x$ & & \\
\hline & & Asphalt & $\begin{array}{l}300 \mathrm{~m}(80 \% \\
\text { PCBs) }\end{array}$ & & & & $x$ & & \\
\hline & & Concrele & $\begin{array}{l}300 \mathrm{~m}(80 \% \\
\text { PCBs) }\end{array}$ & & & & $x$ & & \\
\hline & & Multi-Layer Cap & $300 m_{\text {PCBs) }}(80 \%$ & & & & $x$ & & \\
\hline & \multirow[t]{2}{*}{ Excavation } & $\begin{array}{l}\text { Mechanical } \\
\text { Dredging }\end{array}$ & $\begin{array}{l}573 \mathrm{~m}^{3}(80 \% \\
\text { PCBs) }\end{array}$ & & & & & 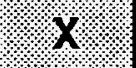 & 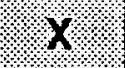 \\
\hline & & $\begin{array}{l}\text { Hydraulic } \\
\text { Dredging }\end{array}$ & $\begin{array}{l}573 \mathrm{~m}^{\prime}(80 \% \\
\text { PCBs) }\end{array}$ & & & & & $x$ & $x$ \\
\hline & $\begin{array}{l}\text { Ex-Situ } \\
\text { Solidification }\end{array}$ & $\begin{array}{l}\text { Micro- } \\
\text { encapsulation }\end{array}$ & $\begin{array}{l}\text { Sediment }>50 \\
\text { ppm PCB }\end{array}$ & & & & & $x$ & \\
\hline
\end{tabular}


Table 4.1. (contd)

\begin{tabular}{|c|c|c|c|c|c|c|c|c|c|}
\hline \multirow{2}{*}{\multicolumn{4}{|c|}{ GENERAL RESPONSE ACTION }} & \multirow{3}{*}{$\begin{array}{c}\text { No } \\
\text { ACTION }\end{array}$} & \multirow{3}{*}{$\begin{array}{l}\text { LIMITED } \\
\text { ACTION }\end{array}$} & \multicolumn{2}{|c|}{ CONTAINMENT } & \multirow{3}{*}{$\begin{array}{l}\text { REMOVE } \\
\text { AND } \\
\text { DISPOSE }\end{array}$} & \multirow{3}{*}{$\begin{array}{l}\text { REMOVE } \\
\text { AND } \\
\text { TREAT }\end{array}$} \\
\hline & & & & & & \multirow{2}{*}{$\begin{array}{c}\text { In Situ } \\
\text { Capping }\end{array}$} & \multirow{2}{*}{$\begin{array}{c}\text { Stream } \\
\text { Diversion }\end{array}$} & & \\
\hline Medium & $\begin{array}{c}\text { Technology } \\
\text { Type }\end{array}$ & Process Option & $\begin{array}{l}\text { Area or } \\
\text { Volume }\end{array}$ & & & & & & \\
\hline \multirow[t]{10}{*}{ Sediment } & \multirow[t]{2}{*}{$\begin{array}{l}\text { Ex-Situ } \\
\text { Physical } \\
\text { Treatment }\end{array}$} & $\begin{array}{l}\text { Soil Washing } 1 \\
\text { Size } \\
\text { Segregation }\end{array}$ & $\begin{array}{l}573 \mathrm{~m}^{2}(80 \%) \\
\mathrm{PCBs})\end{array}$ & & & & & $x$ & $x$ \\
\hline & & Dewatering & $\begin{array}{l}573 \mathrm{~m}^{3}(80 \% \\
\text { PCBs) }\end{array}$ & & & & & $x$ & $x$ \\
\hline & $\begin{array}{l}\text { Ex-Situ Bio. } \\
\text { Trealment }\end{array}$ & $\begin{array}{l}\text { Land Farming / } \\
\text { Composting }\end{array}$ & $\begin{array}{l}573 \mathrm{~m}^{\prime}(80 \% \\
\text { PCBs) }\end{array}$ & & & & & & $\mathrm{X}$ \\
\hline & \multirow[t]{2}{*}{$\begin{array}{l}\text { Ex-Sinu } \\
\text { Thermal Treat. }\end{array}$} & $\begin{array}{l}\text { Thermal } \\
\text { Desorption }\end{array}$ & $\begin{array}{l}100 \mathrm{~ms}^{\prime}(29 \% \\
\mathrm{PCBs})\end{array}$ & & & & & & $x$ \\
\hline & & Incineration & $100 \mathrm{~m}^{3}(29 \%$ & & & & & & $x$ \\
\hline & \multirow[t]{2}{*}{$\begin{array}{l}\text { Ex-Situ Chem. } \\
\text { Treatment }\end{array}$} & $\begin{array}{l}\text { Solvent Washing } \\
\text { I Extraction }\end{array}$ & $\left\{\begin{array}{l}573 \mathrm{~m}^{3}(80 \% \\
\text { PCBs) }\end{array}\right.$ & & & & & & $x$ \\
\hline & & $\begin{array}{l}\text { Dechlorination } \\
\text { (KPEG) }\end{array}$ & $\mid \begin{array}{l}100 \mathrm{~m}^{3}\{29 \% \\
\mathrm{PCBs}\}\end{array}$ & & & & & & $x$ \\
\hline & \multirow[t]{2}{*}{ Landtiil } & $\begin{array}{l}\text { Chemical Waste } \\
\text { Landfill }\end{array}$ & $100 \mathrm{~m}^{2}(29 \%$ & & & & & $\mathrm{X}$ & \\
\hline & & On Site Landtill & $\begin{array}{l}573 \mathrm{~m}^{3}(80 \% \\
\text { PCBs) }\end{array}$ & & & & & $\mathrm{X}$ & $x$ \\
\hline & Use as Fill & Fill Material & $\begin{array}{l}\text { Sedimen! }<1 \\
\text { ppm PCB }\end{array}$ & & & & & $x$ & $x$ \\
\hline & LEGEND: & $1 \%$ & $\begin{array}{l}\text { Selected lor } \\
\text { Analysis }\end{array}$ & & $x$ & $\begin{array}{l}\text { Not } \\
\text { Selected }\end{array}$ & & & $\begin{array}{l}\text { Not } \\
\text { Applicable }\end{array}$ \\
\hline
\end{tabular}

Physical Fish Controls: Physical controls (fish control dam or screens) would be installed in the lower portion of Garrison Slough to prevent the migration of fish into the contaminated portion of the slough. These controls would prevent further bioaccumulation of PCBs by fish that have migrated out of the slough. They would eventually reduce PCB concentrations in the fish population when those previously contaminated reach their life expectancy ( $\sim 8$ years).

Both process options (fish screens and fish control dam) passed the screening process. However, an evaluation of these options (Figure 3.2) suggests that screens would plug with debris and thus would require more maintenance. As a result, the fish screen option has not been included in this alternative. Instead, a rock dam ( 1 meter [3 ft] high) would be installed just upstream from the slough's confluence with an unnamed stream near the intersection of Flightline and Central Avenues (Figure 4.1 ). (o) $^{\text {(a) }}$ The rock dam would be constructed with a vertical to very steep downstream face to prevent the upstream migration of fish.

(a) Assuming a gradient of $1 \mathrm{~m} / \mathrm{km}$, this dam would back up water in the slough approximately $1 \mathrm{~km}$. 


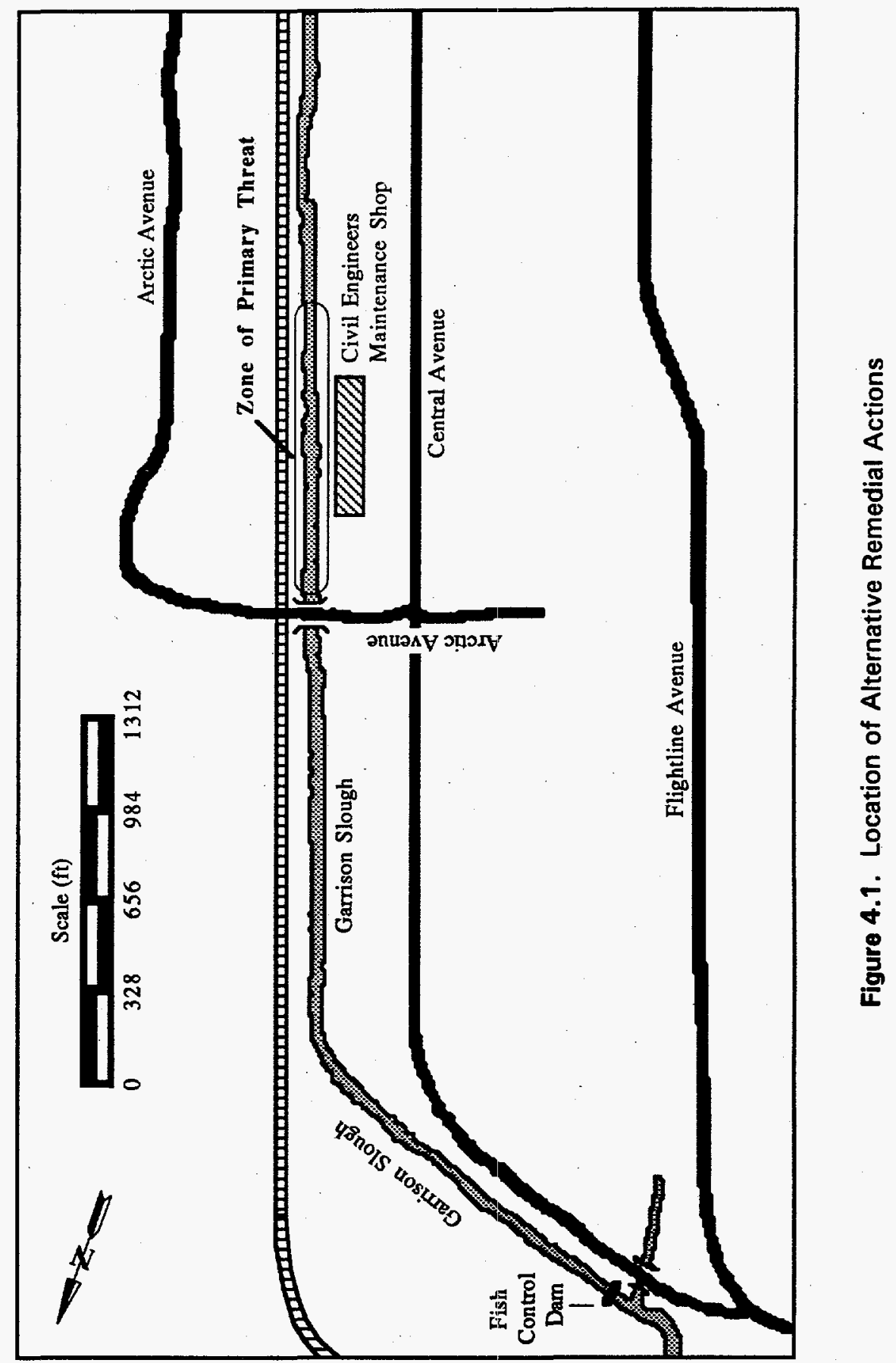




\subsubsection{In Situ Capping}

The In Situ Capping alternative seeks to meet the RAOs by promulgating a fish advisory/restrictions and by isolating the majority of the PCBs from the ecosystem. The Fishing Advisory/Restrictions would provide a near immediate reduction in the amount of fish ingested from Garrison Slough, while isolating the PCBs would (over time) reduce the PCB concentration in the fish population.

Two process options for capping/lining the slough bottom, passed the technology screening. These options were: 1) lining of the stream with a corrugated metal culvert (preferably as a half pipe) directly into the stream, and 2) capping of the stream bottom with a multilayer barrier. The capital cost to install the culvert is estimated to be 2.5 times that for installation of the multilayer cap. For this reason, the multilayer cap process option has been selected to represent the in situ capping alternative.

Fishing Advisory/Restrictions: As discussed previously, Fishing Advisory/Restrictions would be promulgated by the Alaska State Department of Fish and Game, warning residents that ingestion of more that 1 meal of fish per year could pose an unacceptable health risk ( $>10^{-8}$ excess cancers) and designate Garrison Slough as catch-and-release-only. After the concentration in the fish population is shown to have decreased to acceptable levels (due to isolation of the PCBs and the natural death rate of the fish), the fishing restriction will be lifted.

Multilayer Cap: A 300-m (1000-ft) long stretch of lower Garrison Slough would be lined with a multilayer cap to isolate a preponderance of the PCB contaminated sediment from the ecosystem. The portion of the slough to be lined would be from just upstream of sampling station GS41 to Arctic Avenue (Figure 4.1). This portion of the slough contains $-80 \%$ of the mass of the PCB contamination.

Capping would be performed in late summer when surface water flows are their lowest, and the groundwater table is near its deepest. Surface water would be routed around the capping area to reduce the potential for sediment resuspension and transport, and to make installation of the liner less complicated. Two small temporary dams, one upstream and one downstream of the targeted dredging area, would be constructed. Water from the slough would be diverted around this portion of the slough, using large trailer-mounted pumps and PVC piping. Another small pump would be used to dewater the now isolated portion of the slough in preparation for capping.

After minimal preparation of the stream bed (devegetation and contouring), a permeable geotextile liner would be installed, and covered by successive $10-15 \mathrm{~cm}(4-6 \mathrm{in}$.$) thick layers of pea gravel;$ coarse pebble, and cobble. The permeable liner would to permit any gases formed during decomposition of organic mater to escape and not lift the liner. The complete liner is estimated to raise the bed of the slough 30 to $45 \mathrm{~cm}(12$ to $18 \mathrm{in.}$.).

\subsubsection{Divert Stream}

Another alternative for isolating the PCBs from the aquatic ecosystem, thereby making the PCBs unavailable for bioaccumulation, is to divert the stream through a new channel or a large culvert. Such diversion essentially cuts off the source of PCBs from the fish. A Fishing Advisory and Catch-and-Release Restrictions would be promulgated to control the ingestion of fish over the short term. After the PCBs have been isolated, and the concentration in fish has decreased to acceptable levels, the Fishing Advisory/Restrictions would be lifted. 
This alternative is primarily directed at isolating the principal threat, that area containing a predominance of the contamination. The portion of the stream to be bypassed would consist of approximately $300 \mathrm{~m}(1000 \mathrm{ft}$ ) immediately upstream of Arctic Avenue (Figure 4.1). Although diverting the stream via excavation of a new channel passed the initial screening process, implementability is questionable along the narrow corridor between the Civil Engineers' Maintenance. Shop and the railroad tracks (Figure 4.1). Thus, lining the stream with a multilayer cap (Section 4.2.3) has been selected to represent the containment/isolation alternative.

\subsubsection{Dredge and Dispose}

This alternative was developed to meet the RAOs by first promulgating a Fishing Advisory and Restrictions to reduce risks over the short term and second to remove a preponderance of PCB contamination, thereby reducing the long-term risks. In this alternative, the contaminated sediments removed from the slough would then be safely disposed. Several alternatives were assembled based on the choice of removal and disposal options (Section 4.1). However, the alternative selected to be representative of the general disposal response alternative for detailed analysis and comparison against other general response alternatives, consists of a temporary fish advisory/ restrictions, and mechanical dredging of the most contaminated sediments, followed by on-site disposal of the dredged material. A brief description of the various components and their selection in the representative disposal alternative follows.

Fishing Advisory/Restrictions: Fishing Advisory/Restrictions would be promulgated by the Alaska State Department of Fish and Game, warning residents that ingestion of more that 1 meal ( $300 \mathrm{~g})$ of fish per year could pose an unacceptable health risk $\left(>10^{-8}\right.$ excess cancers) and/or designate Garrison Slough as catch-and-release-only. When the concentration in the fish population is shown to have decreased to acceptable levels (due to removal of the PCBs and the natural death rate of the fish), the Fishing Advisory/Restriction would be lifted.

Dredging: Removal of the contaminated sediment from the slough would prevent further bioaccumulation in fish. This action would (over time) lead to a reduction in the PCB concentration in the fish population. Two process options for removal of PCB contaminated sediments, passed the technology screening process and were qualitatively evaluated for their efficiency, implementability, and relative cost (Section 3.2). Both mechanical (via backhoe) and hydraulic vacuum dredging were evaluated. Mechanical dredging (in combination with temporary damming and by-passing of the targeted dredging area) was selected as the representative process option because hydraulically dredged material would have a very high water to solids ratio $(\sim 85: 15)$. Such a high water ratio would make sediment treatment prior to disposal more difficult, and would necessitate the treatment of large amounts of water, prior to its discharge back into the slough. Mechanical dredging of the $300-\mathrm{m}(1000-\mathrm{ft})$ long zone of principal threat (Figure 4.1) would produce an estimated $660 \mathrm{~m}^{3}(860 \mathrm{cu}$ yd) of contaminated sediment.

Disposal: All four disposal process options passed the screering process. These disposal options, together with some pretreatment options, were assembled into four general disposal trains

- Soil Washing and Off-Site Disposal

- Soil Washing, Asphalt Encapsulation, and On-Site Disposal/Reuse

- On-Site Disposal.

- Segregation, On-Site/Off-Site Disposal

Soil Washing and Off-Site Disposal. The soil washing and off-site disposal option consists of separating the contaminant laden fines from the coarse fraction of the sediment, disposal of the 
clean coarse fraction on-site, and disposal of the contaminated fines in a TSCA-regulated chemical waste landfill. Dredged material would undergo size classification and the coarse fractions (sand and gravel) washed with a detergent solution to remove the silts and clays. The clean coarse fraction would be tested and disposed of as fill into the slough channel. The fine fraction would be dewatered, stabilized, packaged, and shipped to Arlington, Washington, for disposal.

Soil Washing, Asphalt Encapsulation, and On-Site Disposal/Reuse. In this option the dredged material would be screened and washed, with the clean coarse fraction used as fill (back to slough channel). The fine fraction would be mixed with and encapsulated into a cold asphalt emulsion, and either disposed to a landfill (the on-base asbestos landfill) or used as a subgrade material for onbase road construction. An advantage of this option is that a local contractor provides this service.

On-Site Disposal. Disposal on site, would consist of hauling the dredged material directly to a selected landfill (the on-base asbestos landfill). Disposal of dredge material $50 \mathrm{ppm}$ and greater in a method other than in a chemical waste landfill requires the approval of the EPA's regional administrator [EPA 1990; 40 CFR 761.60 (a) (5)]: However, the low concentration of PCBs $165.6 \mathrm{ppm}$ max.), the inherently low solubility $(2.7 \mathrm{E}-3 \mathrm{mg} / \mathrm{L}$ ), and high sorption (as indicated high octanolwater partitioning $\left[K_{o w}=14 E+6\right]$ ] of Aroclor-1260 (EPA 1990) indicates that land disposal is a reasonable and prudent option. Based on the expected low cost, on-site disposal was selected as the representative disposal option for detailed analysis.

Segregation, Off-Site/On-Site Disposal. Dredged material from the portion of the slough containing $\geq 50 \mathrm{ppm}$ would be segregated from the material remaining in the principal threat area. The $\geq 50 \mathrm{ppm}$ fraction, estimated at $100 \mathrm{~m}^{3}$ (130 cu yd) would be dewatered, stabilized, packaged, and shipped to Arlington, WA, for disposal at a permitted chemical waste landfill. The remaining dredge material $\left(<50 \mathrm{ppm}\right.$ ), estimated at $560 \mathrm{~m}^{3}$ (730 cu yd) would be disposed of directly to an on-base landfill.

\subsubsection{Dredge and Treat}

The Dredge and Treat alternative focuses on meeting the RAOs by first promulgating a Fishing Advisory/Restrictions and then eliminating a preponderance of the contamination so that fish could no longer bioaccumulate the PCBs. The fishing restrictions would provide nearly immediate reduction in the amount of fish ingested from Garrison Slough; removing most of the PCBs would, over time, reduce the PCB concentration in the fish population. Ex situ treatment of the removed. sediment would permanently destroy the PCBs.

Several alternatives were assembled based on the choice of removal and treatment options (Section 4.1). However, the one alternative selected as representative of the general treatment response alternative (and to be used for detailed analysis and comparison against other general response alternatives) consists of temporary fish advisory/restrictions, and mechanical dredging of most contaminated sediments, followed by land farming bioremediation. A brief description of the various components and their selection in the representative treatment alternative follows.

Fishing Advisory/Restrictions: A Fishing Advisory/Restrictions would be promulgated by the Alaska State Department of Fish and Game warning residents that ingestion of more that 1 meal $1300 \mathrm{~g}$ [10.6 oz]) of fish per year could pose an unacceptable health risk (>10 $0^{-6}$ excess cancers) and/or designate Garrison Slough as a Catch-and-Release-only. When the concentration in the fish population is shown to have decreased to acceptable levels Idue to removal of the PCBs and the natural death rate of the fish), the Fishing Advisory/Restriction would be lifted. 
Dredging: Removal of the contaminated sediment from the slough would prevent further bioaccumulation in fish. This would, over time, lead to a reduction in the PCB concentration in the fish population. Two process options for removal of PCB contaminated sediments, passed the technology screening process and were qualitatively evaluated for their efficiency, implementability, and relative cost (Section 3.2). Both mechanical (via backhoe) and hydraulic vacuum dredging were evaluated. Mechanical dredging (in combination with a temporary damming and bypassing of the target area) was selected as the representative process option because hydraulically dredged material would have a very high water to solids ratio ( $~ 85: 15)$ making sediment treatment more difficult, and necessitating the treatment of large amounts of water prior to discharge back into the slough. Mechanical dredging of the 300-m (1000-ft) long zone of principal threat (Figure 4.1) would produce an estimated $660 \mathrm{~m}^{3}$ (860 cu yd) of contaminated sediment.

Ex Situ Treatment: Ex situ treatment technologies and process options that passed through the screening process (Section 3.2) include those that reduce the volume, dewater the sediments, encapsulate the contaminated sediment, remove PCBs from the sediment, and/or permanently destroy the PCBs. These treatment technologies and process options were assembled into several alternative treatment trains (Table 4.1) aimed at the permanent destruction of the PCBs. These alternative treatment trains include:

- On-Site Land Farming

- Soil Washing and Off-Site Incineration

- Segregation and On-Site or Off-Site Incineration

- Extensive Soil Washing, Carbon Sorption, and Off-Site Incineration

- Thermal Desorption and Incineration

- Thermal Desorption and Dehalogenation

Land Farming. Land farming would degrade the PCBs over several months to years. White rot fungus, Phanerocheate Chrysosporium, is used with a cellulose/lignin base food source and nutrients to degrade the PCBs. Sawdust is the most likely food source, although straw could also be used. The degradation might normally be complete in a season. However, due to the short growing season in this arctic region, it is expected that up to three seasons may be required with new inoculations and aeration required at the beginning of each growing season.

Incineration. Incineration alternatives eliminate the PCBs by sending them to a hazardous waste incinerator for EPA approved destruction. Several incineration options were examined, and the segregation and incineration treatment train was selected as the representative incineration alternative. Other incineration treatment options have inherent disadvantages for application in a remote area like Eielson AFB.

Soil washing with either solvents or surfactants and water has been shown to successfully remove PCBs from soil. The effectiveness of soil washing can be severely reduced for certain clay mineralologies and several repeated washings may be necessary. A treatability test of sediments from Garrison Slough is necessary.

The use of thermal desorption prior to incineration requires specialized equipment generally too expensive to build for a small scale remediation. Mobilization and demobilization of the equipment to Fairbanks would not be economical. Contractors with smaller equipment may become available in the future and the high treatment confidence of this approach could warrant a second cost/benefit comparison prior to final selection. 
Mobile incinerators for PCBs cannot be contracted, and shipping all of the contaminated soil (without volume reduction) to an approved PCB incinerator is cost prohibitive $(\sim 2.5 \mathrm{M})$.

Segregation with either on-site or off-site incineration is the most reasonable and implementable incineration alternative. Dredged material from the portion of the slough containing $\geq 50 \mathrm{ppm}$ would be segregated from the remaining material in the principal threat area. The $\geq 50 \mathrm{ppm}$ fraction, estimated at $100 \mathrm{~m}^{3}(160 \mathrm{cu}$ yd) would either be incinerated in the base's coal fired boilers (providing the existing air discharge permit can be modified), or dewatered, packaged, and shipped to an off-site incinerator in Utah. Net transportation costs to the Utah site are estimated at approximately $\$ 98,000$ and net incineration costs are estimated at $\$ 140,000$. The costs for on-site incineration (if permitted) are estimated to be on the order of those for on-site landfarming $(\sim \$ 30,000)$. The treated waste would then be disposed as backfill, or recycled for use as a pavement amendment. The remaining dredge material $(<50-3 \mathrm{ppm})$, estimated at $560 \mathrm{~m}^{3}$ (730 cu yd) would be disposed of directly to an on-base landfill.

Dehalogenation. Dehalogenation of sediments is an emerging technology. The current direction, however, is to apply this technology using thermal desorber equipment as a reactor. Dehalogenation is also used to treat the volatilized products from conventional thermal desorption. The advantage of this treatment option is that PCBs are destroyed on site. The disadvantage for Eielson AFB is the unavailability of suitably sized equipment for economical treatment.

\subsection{EVALUATION OF ALTERNATIVES}

The preliminary evaluation of remedial alternatives for Garrison Slough is summarized in Table 4.2. The full range of alternatives (no action, limited action, containment, disposal, and treatment) has been retained. However, one of the containment/isolation options (divert stream) has not been retained because its implementation is highly questionable due to the narrow corridor between the Civil Engineers' Maintenance Shop and the railroad tracks. Lining the existing stream channel with a culvert was selected as the sole alternative to represent the containment/isolation remedial action.

The alternatives retained for detailed analysis are as follows:

- No Action

- Limited Action

- In Situ Capping

- Dredge and Dispose

- Dredge and Treat 
Table 4.2. Preliminary Evaluation of Alternatives

\begin{tabular}{|c|c|c|c|}
\hline Effectiveness & Implementability & Relative Cost & Evaluation Comments \\
\hline \multicolumn{4}{|l|}{ No Action } \\
\hline $\begin{array}{l}\text { The no action alternative } \\
\text { will not meet the RAOs } \\
\text { over the short term; no } \\
\text { actions are taken to } \\
\text { actively reduce risk from } \\
\text { contaminated fish. May be } \\
\text { effective over the very } \\
\text { long term, due to natural } \\
\text { attenuation and } \\
\text { degradation of the PCBs. }\end{array}$ & $\begin{array}{l}\text { This alternative is very } \\
\text { easily implemented in that } \\
\text { it requires nothing but } \\
\text { continued environmental } \\
\text { monitoring. } \\
\text { May not be publicly } \\
\text { acceptable. }\end{array}$ & $\begin{array}{l}\text { Essentially no capital or } \\
\text { O\&M costs. } \\
\text { High long-term monitoring } \\
\text { costs for both fish and } \\
\text { sediment concentrations. }\end{array}$ & $\begin{array}{l}\text { Taking no action will not } \\
\text { meet the RAOs of either } \\
\text { the fish or the sediment, } \\
\text { and will not reduce the } \\
\text { risk to human health and } \\
\text { environment, at least for } \\
\text { quite some time. } \\
\text { However, this alternative } \\
\text { is retained as required } \\
\text { under the NCP. }\end{array}$ \\
\hline \multicolumn{4}{|l|}{ Limited Action } \\
\hline $\begin{array}{l}\text { Fish Advisory/ Restrictions: } \\
\text { Promulgation of fishing } \\
\text { advisory should be } \\
\text { effective in reducing the } \\
\text { health risk from ingestion } \\
\text { of fish, particularly over } \\
\text { the short term. Issuance } \\
\text { of Catch-and-Release-Only } \\
\text { restrictions would provide } \\
\text { an added level of } \\
\text { protection. }\end{array}$ & $\begin{array}{l}\text { This alternative should be } \\
\text { relatively easy to } \\
\text { implement but requires } \\
\text { action on the part of the } \\
\text { State Department of Fish } \\
\text { and Game However, it } \\
\text { may meet with some public } \\
\text { resistance. }\end{array}$ & $\begin{array}{l}\text { The costs for this } \\
\text { alternative would be fairly } \\
\text { minimal. The State } \\
\text { Department of Fish and } \\
\text { Game would be the ones } \\
\text { promulgating the fish } \\
\text { advisory/restrictions. }\end{array}$ & $\begin{array}{l}\text { This alternative will } \\
\text { potentially meet the RAOs } \\
\text { for fish. It provides a } \\
\text { quick solution, which } \\
\text { should be fairly essy to } \\
\text { implement, and represents } \\
\text { the low cost alternative. }\end{array}$ \\
\hline $\begin{array}{l}\text { Physical Fish Controls: A } \\
\text { fish control dam should be } \\
\text { fairly effective in isolating } \\
\text { the fish from the PCB } \\
\text { contaminated sediments. } \\
\text { This should lead to a } \\
\text { reduction in the PCB } \\
\text { concentrations in fish over } \\
\text { time However, the } \\
\text { permanence of this } \\
\text { alternative is questionable, } \\
\text { due to the possible } \\
\text { migration of contaminated } \\
\text { sediments downstream, } \\
\text { past the fish control dam. }\end{array}$ & $\begin{array}{l}\text { Installation of fish controls } \\
\text { should also be relatively } \\
\text { easy to implement } \\
\text { requiring only the } \\
\text { installation of an earthen } \\
\text { dam. Implementation may } \\
\text { impact potential salmon } \\
\text { spawning areas. }\end{array}$ & $\begin{array}{l}\text { Installation of the fish } \\
\text { control dam is expected to } \\
\text { have low capital costs and } \\
\text { moderate maintenance } \\
\text { costs. } \\
\text { Costs for long-term } \\
\text { monitoring would remain } \\
\text { high. }\end{array}$ & $\begin{array}{l}\text { Thus, this alternative is } \\
\text { retained for detailed } \\
\text { analysis. }\end{array}$ \\
\hline
\end{tabular}


Table 4.2. (contd)

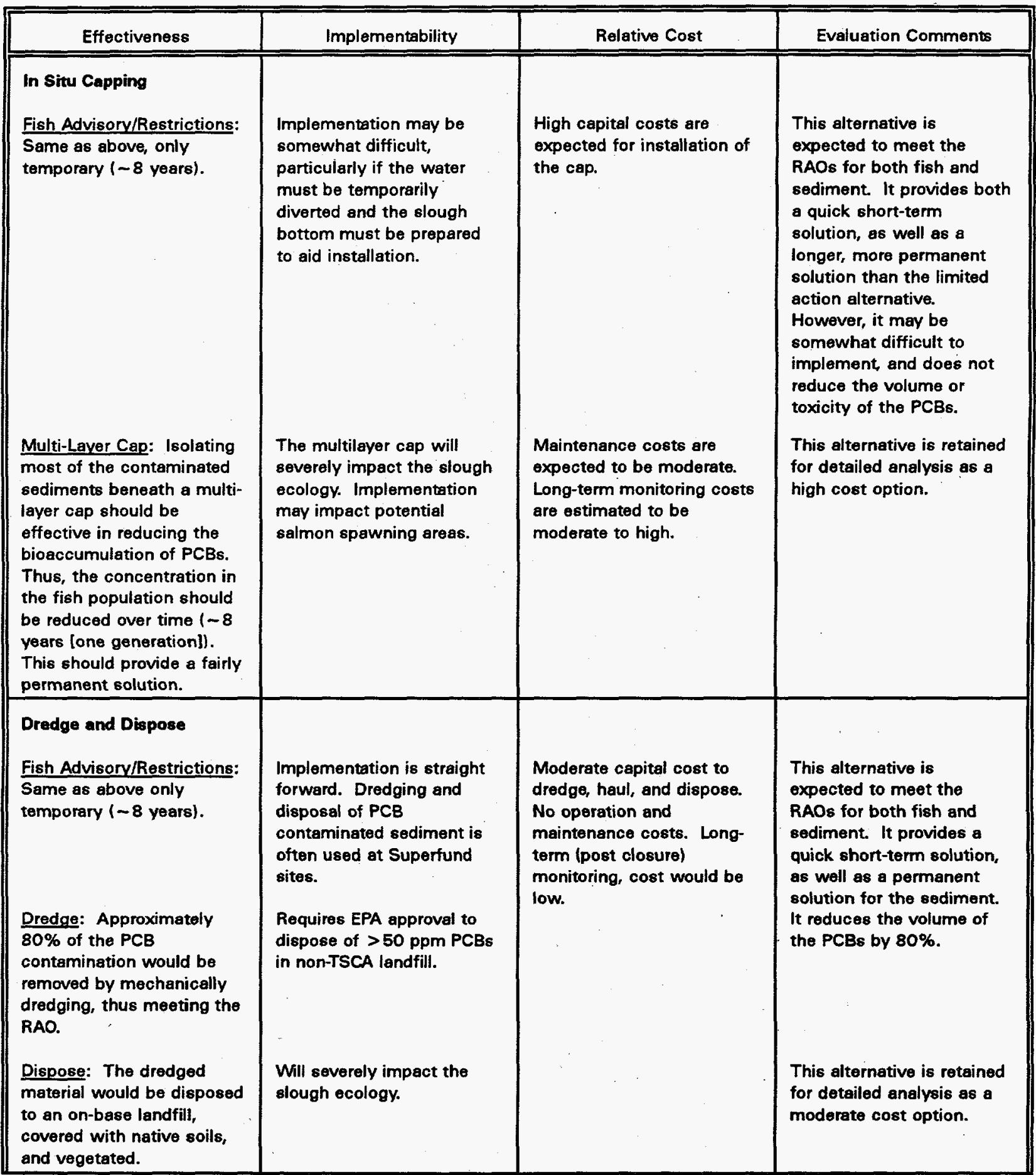


Table 4.2. (contd)

\begin{tabular}{|c|c|c|c|}
\hline Effectiveness & Implementability & Reliative Cost & Evaluation Comments \\
\hline Dredge and Treat & & & \\
\hline $\begin{array}{l}\text { Fish Advisory/Restrictions: } \\
\text { Same as above, only } \\
\text { temporary ( }-8 \text { years). }\end{array}$ & $\begin{array}{l}\text { Fairly easy to implement as } \\
\text { described above. } \\
\text { Biodegradation may take } \\
\text { several summers to } \\
\text { complete. May require } \\
\text { some treatability testing. }\end{array}$ & $\begin{array}{l}\text { Moderate capital costs for } \\
\text { dredging and hauling. }\end{array}$ & $\begin{array}{l}\text { This alternative is } \\
\text { expected to meet the } \\
\text { RAOs for both fish and } \\
\text { sediment. It provides a } \\
\text { quick, short-term solution } \\
\text { as well as a permanent } \\
\text { solution for the sediment. }\end{array}$ \\
\hline $\begin{array}{l}\text { Dredge: Approximately } \\
80 \% \text { of the PCB } \\
\text { contemination would be } \\
\text { removed by mechanically } \\
\text { dredging, thus meeting the } \\
\text { RAO. }\end{array}$ & $\begin{array}{l}\text { Will severely impact the } \\
\text { slough ecology. }\end{array}$ & $\begin{array}{l}\text { Moderate operation and } \\
\text { maintenance costs during } \\
\text { landfarming operations. }\end{array}$ & $\begin{array}{l}\text { It not only reduces the } \\
\text { volume of the PCBs by } \\
80 \% \text {, it also permanently } \\
\text { destroys the PCBs. }\end{array}$ \\
\hline $\begin{array}{l}\text { Treat: The dredged } \\
\text { material would be } \\
\text { biodegraded using } \\
\text { landfarming technologies. } \\
\text { Treated soils would be left } \\
\text { at the treatment site. }\end{array}$ & & & $\begin{array}{l}\text { This alternative is retained } \\
\text { for detailed analysis as a } \\
\text { moderate to high cost } \\
\text { option. }\end{array}$ \\
\hline
\end{tabular}




\subsection{DETAILED ANALYSIS OF ALTERNATIVES}

This section provides the detailed description and evaluation of the alternatives selected for analysis. The alternative descriptions identify the technologies, describe the representative process options, and present the assumptions that were necessary to provide an analysis of each individual alternative against the NCP alternative evaluation criteria outlined in Table 5.1. The detailed analysis is presented by alternative. Each alternative includes consideration of contaminated fish and sediment. Information on the assumptions and calculations used in the development and evaluation of each alternative is provided in Appendix A. The detailed cost analysis for each alternative is provided in Appendix $B$.

Table 5.1. NCP Criteria for Evaluating Alternatives

\begin{tabular}{|c|c|}
\hline Criterion & Description \\
\hline $\begin{array}{l}\text { Overall protection of human health } \\
\text { and the environment }\end{array}$ & $\begin{array}{l}\text { Alternatives shall be assessed to determine whether they adequately protect } \\
\text { human health and the environment from unacceptable risks, both short- and long- } \\
\text { term, by eliminating, reducing, or controlling exposures to contaminants. }\end{array}$ \\
\hline $\begin{array}{l}\text { Compliance with applicable or } \\
\text { relevant and appropriate } \\
\text { requirements (ARAR) }\end{array}$ & $\begin{array}{l}\text { Alternatives shall be assessed to determine whether they attain federal and state } \\
\text { ARARs or provide grounds for invoking a waiver. }\end{array}$ \\
\hline $\begin{array}{l}\text { Long-term effectiveness and } \\
\text { permanence }\end{array}$ & $\begin{array}{l}\text { Alternatives shall be assessed for the long-term effectiveness and permanence } \\
\text { they provide and the degree of certainty they will prove successful. The following } \\
\text { factors shall be considered: (1) magnitude of residual risk remaining after the } \\
\text { alternative is implemented; and (2) adequacy and reliability of the controls } \\
\text { necessary to manage the contaminants. }\end{array}$ \\
\hline $\begin{array}{l}\text { Reduction of toxicity, mobility, or } \\
\text { volume through treatment }\end{array}$ & $\begin{array}{l}\text { Alternatives shall be assessed to determine the degree to which recycling or } \\
\text { treatment is expected to reduce the toxicity, mobility, and/or volume of the waste } \\
\text { or residual contaminants and the degree to which treatment is irreversible. The } \\
\text { quantity, persistence, toxicity, mobility, and propensity to biosccumulate of each } \\
\text { type of residual that will remain after treatment will also be considered. }\end{array}$ \\
\hline Short-term effectiveness & $\begin{array}{l}\text { Alternatives shall be assessed to determine the short-term impacts during } \\
\text { implementation and the time until protection is achieved. The impacts that shall be } \\
\text { considered include risks to the community impacts on workers, and potential } \\
\text { environmental impacts. }\end{array}$ \\
\hline Implementability & $\begin{array}{l}\text { Alternatives shall be assessed for the ease or difficulty of implementation, } \\
\text { including technical feasibility, administrative feasibility, and the availability of } \\
\text { services and materials. }\end{array}$ \\
\hline Cost & $\begin{array}{l}\text { Alternatives shall be assessed to determine direct and indirect capital costs, annual } \\
\text { operation and maintenance costs, and net present value. }\end{array}$ \\
\hline
\end{tabular}


The PRGs for fish were established to protect human health. The target cleanup level for fish is:

- a PCB concentration of $0.69 \mu \mathrm{g} / \mathrm{kg}$ (wet weight)

This fish tissue concentration would produce a total excess cancer risk of less than $10^{-6}$ (for an estimated risk reduction of $10^{-3}$ ). This calculation was based on a recreational exposure scenario (ingestion of fish by an adolescent [300 grams of fish, 30 times/yr for 12 years]).

The goal of remediating contaminated sediment is to reduce the biological uptake of PCB contamination by fish, thereby reducing the PCB concentration in the fish population over time. The cleanup goal is to remove a preponderance $(-80 \%)$ of the PCB contamination in sediments of Garrison Slough.

\subsection{DETAILED DEVELOPMENT OF ALTERNATIVES FOR.GARRISON SLOUGH}

A detailed description has been developed for each of the five alternatives presented in the preliminary screening of alternatives (Section 4.). The descriptions provide the basis for the individual and comparative analyses presented in Section 5.2.

The first two alternatives do not address PRGs. The No Action alternative represents the baseline risk without corrective action. The Limited Action alternative provides a means of limiting human exposures without reducing contaminant concentrations or mobility, except by natural attenuation. The last three alternatives provide increasing levels of control and achievement of PRGs at each level. .However, all of the alternatives will require long-term management of the area.

\subsubsection{No Action Alternative}

The No Action alternative is not expected to achieve remedial action objectives. Natural degradation rates of highly chlorinated PCB congeners (such as those in Aroclor 1260) are extremely slow (Rhee et. al. 1993). Thus, the time required to achieve the PRG for fish without any remedial action is estimated to be on the order of tens of years (Appendix A, Section A.1.1).

\subsubsection{Limited Action Alternative}

The Limited Action alternative would use institutional controls to limit current and future exposures to contaminated fish, and engineering controls to limit the exposure of fish to the source of PCBs. The Limited Action alternative does not directly address the remedial action objectives except by natural attenuation. Although the natural degradation rate for highly chlorinated PCBs is very slow, isolation of fish from the source of the PCBs is expected to reduce their PCB tissue concentration over time. The time required for the concentration in the fish population to decrease (hopefully to the PRG levels) is estimated to approximate the life expectancy of the fish ( $\sim 8$ years).

The principal components of the Limited Action alternative are presented in Figure 5.1 and summarized as follows.

Fish: Institutional controls would be used to limit current and future exposures to contaminated fish. A Fish Advisory and/or Catch-and-Release restrictions would be promulgated by the Alaska State Department of Fish and Game. The advisory would state that ingestion of more than 1 meal $(\geq 300 \mathrm{~g})$ of fish per year from Garrison Slough may pose an unacceptable health risk $\left(>10^{-6}\right.$ 
excess cancers) and should be avoided. This procedure would help to reduce the health risk to the population, but would not prevent exposure to contaminated fish. Designation of Garrison Slough as a Catch-and-Release-Only area, would essentially prevent the ingestion of contaminated fish.

Physical Fish Controls: Engineering controls would be installed in the lower portion of Garrison Slough to prevent the migration of fish into the contaminated portion of the slough. An earthen dam ( 1 meter [3.3 ft] high) would be installed just upstream from the slough's confluence with the unnamed stream near the intersection of Flightline and Central Avenues. This earthen dam would be constructed with a vertical to very steep downstream face to prevent the upstream migration of fish. This dam would prevent further bioaccumulation of PCBs by fish; eventually reducing the PCB concentrations in the fish population.

However, this dam would also raise the water level in the slough causing subsequent changes in the slough's ecosystem. PCBs would also continue to move and be available for bioaccumulation within the isolated portion of the slough.

\subsubsection{In Situ Capping Alternative}

The In Situ Capping alternative seeks to meet the RAOs by promulgating a Fish Advisory and/or Restrictions and by isolating the majority of the PCBs from the ecosystem. The Fishing Advisory/ Restrictions would provide a near immediate reduction in the amount of fish ingested from Garrison Slough, while isolating the PCBs is expected, over time, to reduce the PCB concentration in the fish population.

The most important components of the In Situ Capping alternative are summarized in Figure 5.2 and briefly outlined as follows.

Fish: Institutional controls would be used to limit current and short-term future exposures to contaminated fish. A temporary Fish Advisory and/or Catch-and-Release restrictions would be promulgated by the Alaska State Department of Fish and Game to limit and/or prevent the ingestion of contaminated fish. Once the PCB concentration in the fish population is shown to have decreased to meet RAO levels (due to isolation of the PCBs and the natural death rate of the fish), the Fishing Advisory/Restrictions would be lifted.

Sediment Capping: A 300-m (1000-ft) long stretch of lower Garrison Slough would be lined with a multilayer cap to isolate a preponderance of the PCB contaminated sediment from the ecosystem. The portion of the slough to be lined would be located immediately upstream of Arctic Avenue to just upstream of sampling station GS41 (Figure 5.2). This portion of the slough contains $\sim 80 \%$ of the mass of the PCB contamination, and thus would meet the RAO for sediment. 


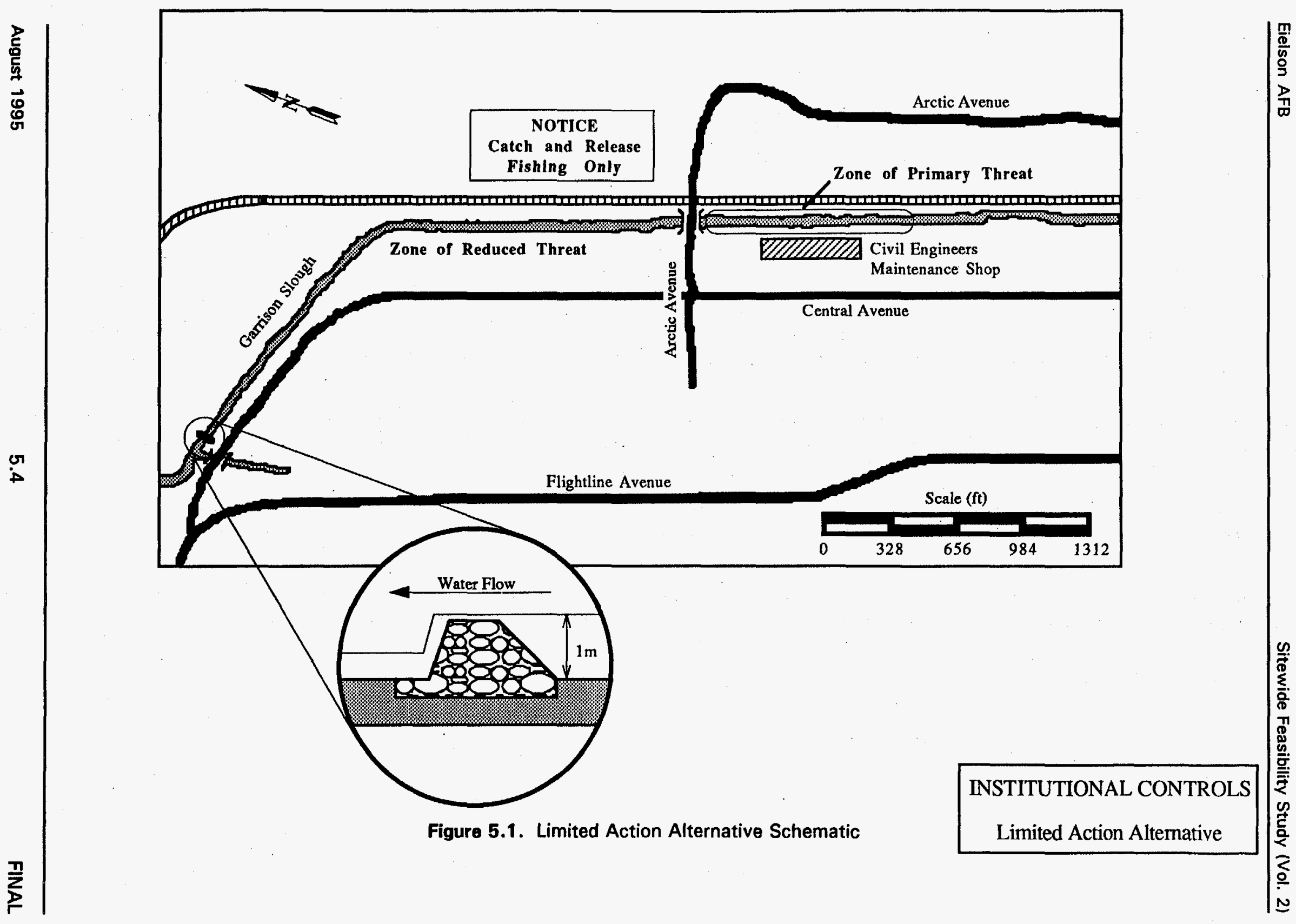


$20 \mathrm{~cm}$ (8 in) Diameter PVC Piping - Up to 4500 GPM Pumped Around Contaminated Area

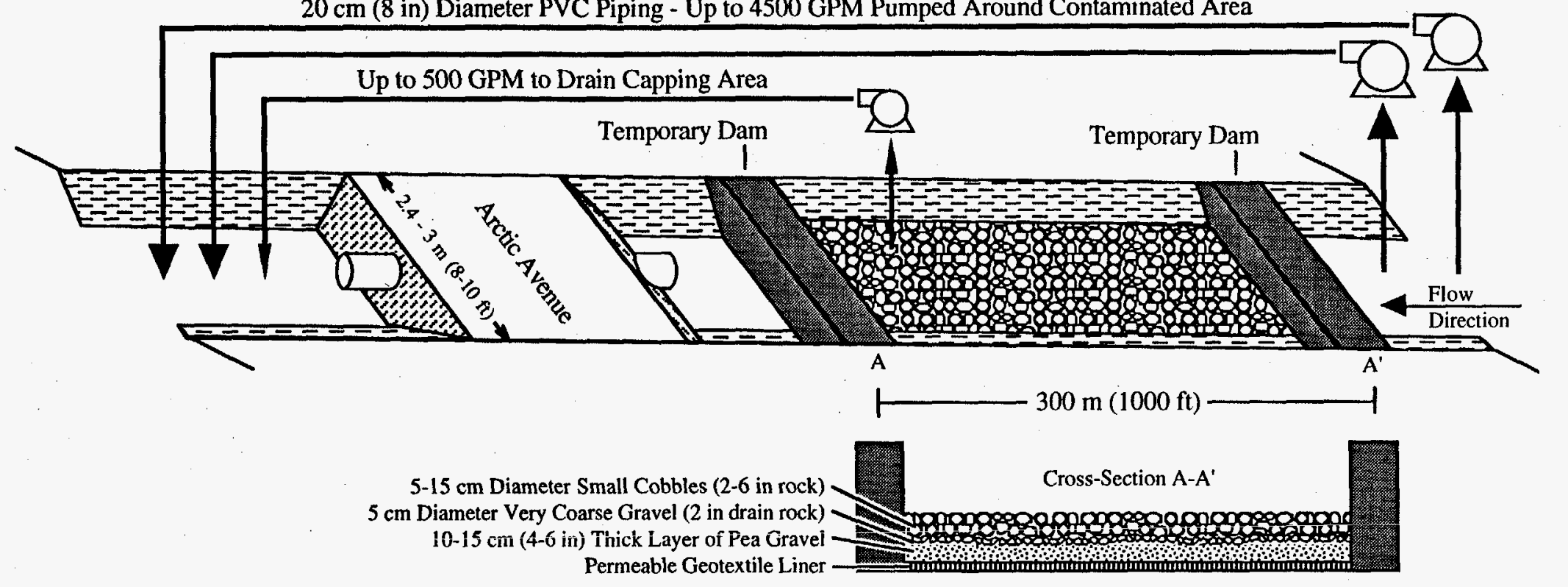

IN SITU CAPPING

Multi-Layer Cap Alternative

Figure 5.2. In Situ Capping Alternative Schematic 
The stream here is estimated to be 2.4 to 3 meters $(8-10 \mathrm{ft})$ wide and 0.3 to 0.6 meters $(1-2 \mathrm{ft})$ deep with an estimated flow rate of 0.1 to over $4.2 \mathrm{~m}^{3} / \mathrm{sec}\left(4\right.$ to $\left.150 \mathrm{ft}^{3} / \mathrm{sec}\right)$. Capping would be performed in late summer when surface water flows are their lowest, and the groundwater table is near its deepest. Surface water would be routed around the capping area to reduce the potential for sediment resuspension and transport, and to make installation of the liner less complicated. Two small temporary dams, one upstream and one downstream of the targeted dredging area, would be constructed. Water from the slough would be diverted around this portion of the slough using two $110 \mathrm{l} / \mathrm{s}(1700 \mathrm{gpm}$ ) pumps and 20-cm dia. (8-in.) PVC piping. Another pump would be used to dewater the now isolated portion of the slough in preparation for capping.

After minimal preparation of the stream bed (devegetation and contouring), a permeable geotextile liner would be installed, and covered by successive $10-15 \mathrm{~cm}(4-6 \mathrm{in}$.) thick layers of pea gravel; $5-\mathrm{cm}$ dia. very coarse pebble (2-in. drain rock), and finally $5-$ to $15-\mathrm{cm}$ dia. small cobble $12-6$ in. rock). A permeable liner would permit any gases formed during decomposition of organic mater to escape and not lift the liner. The complete liner is estimated to raise the bed of the slough 30 to $45 \mathrm{~cm}$.

\subsubsection{Dredge and Dispose Alternative}

The Dredge and Dispose alternative was developed first to meet the RAOs by promulgating a temporary Fishing Advisory and/or Catch-and-Release restrictions to reduce risks over the short term, and second to remove and dispose of a preponderance of PCB contamination, thereby reducing the long term risks. In this alternative, the contaminated sediments will be removed from the slough and safely disposed in an existing base landfill.

The most important components of the Dredge and Dispose alternative are summarized in Figure 5.3 and briefly outlined below.

Fish: A Fishing Advisory/Restrictions would be promulgated by the Alaska State Department of Fish and Game warning residents that ingestion of more that 1 meal $(300 \mathrm{~g})$ of fish per year could pose an unacceptable health risk $\left(10^{-6}\right.$ excess cancers) and/or designate Garrison Slough as a Catch-andRelease-Only. Once the concentration in the fish population is shown to have decreased to acceptable levels (due to removal of the PCBs and the natural death rate of the fish), the Fishing Advisory/Restriction would be lifted.

Sediment Removal and On-Base Disposal: The preponderance of PCB contamination would be removed by mechanically dredging (in combination with temporary damming and bypassing of the targeted dredging area) approximately 300 linear meters (1000 ft) of Garrison Slough, immediately upstream of Arctic Avenue (Figure 5.3). This portion of the slough is estimated to contain $\sim 80 \%$ of the mass of the PCB contamination. Thus, this action would meet the RAO for sediment.

Dredging activities would be performed in late summer when surface water flows are their lowest, and the groundwater table is near its deepest. Surface water would be routed around the targeted dredging area to reduce the potential for sediment resuspension and transport, and to reduce the amount of water picked up during the dredging operation. 


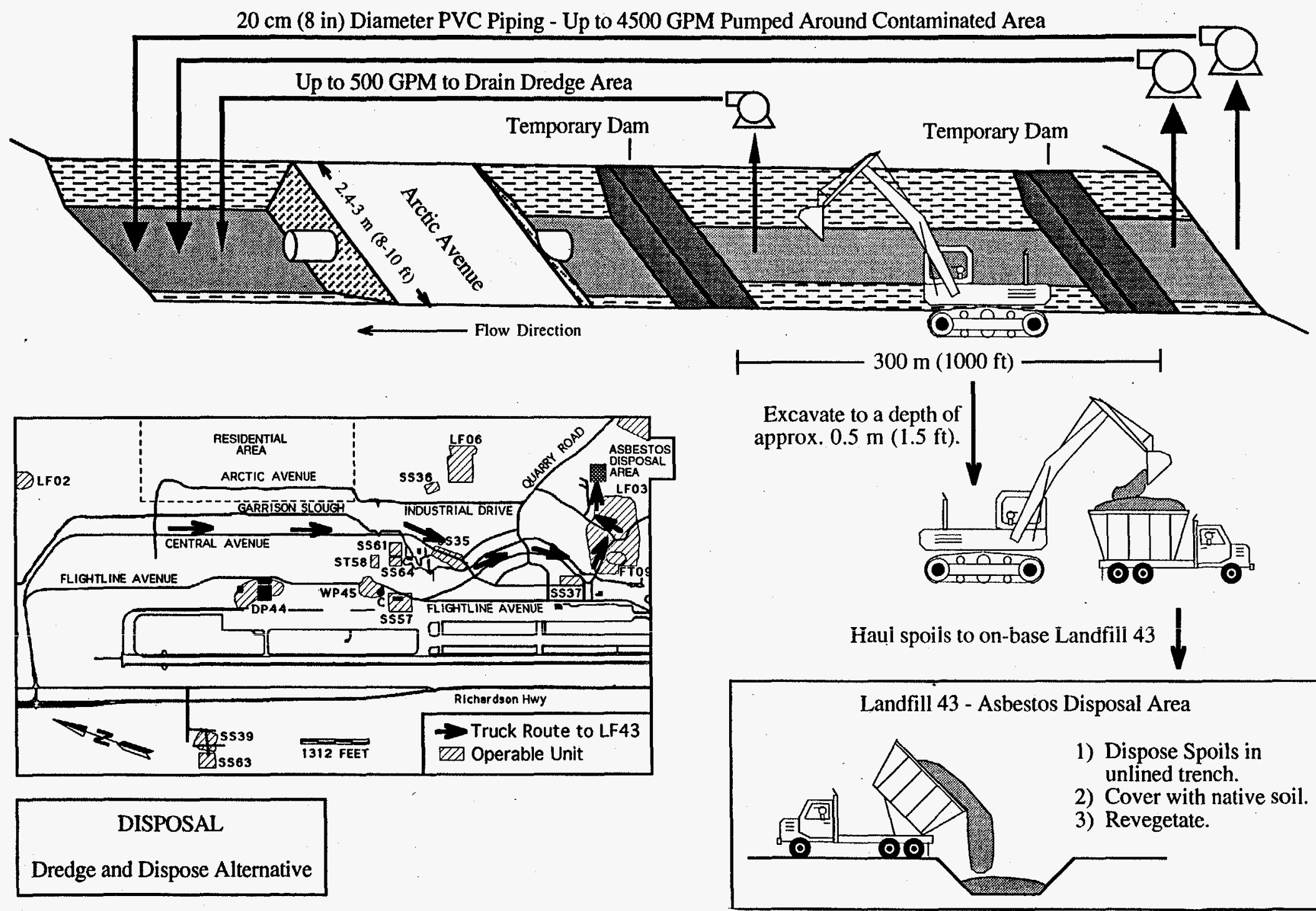

Figure 5.3. Dredge and Dispose Alternative Schematic 
Two small temporary dams, one upstream and one downstream of the targeted dredging area, would be constructed. Water from the slough would be diverted around this portion of the slough using two $110 \mathrm{l} / \mathrm{s}(1700 \mathrm{gpm}$ ) pumps and 20-cm dia. (8 inch) PVC piping. A trackhoe would be used to excavate the sediment to a depth of approximately $0.6 \mathrm{~m}(2 \mathrm{ft})$ plus a $10 \%$ over dig and place the spoil directly into dump trucks. Each truckload of dredge material from the $>50 \mathrm{ppm}$ contamination zone would be sampled to determine its bulk concentration. Assuming the bulk concentration is $<50 \mathrm{ppm}$ and/or if disposal of $50 \mathrm{ppm}$ PCB in onsite landfill has been accepted, the estimated $660 \mathrm{~m}^{3}$ ( $860 \mathrm{cy}$ yd) of dredge material would be hauled to an on-base landfill (the asbestos (andfill) and disposed directly to an unlined trench. The dredge materials would be covered with native soils, and revegetated.

\subsubsection{Dredge and Treat Alternative}

The Dredge and Treat alternative was developed first to meet the RAOs by promulgating a temporary Fishing Advisory and/or Catch-and-Release restrictions to reduce risks over the short term, and second to remove a preponderance of the PCB contaminated sediment, there by reducing the longterm risks. In this alternative, the contaminated sediments would be removed from the slough, treated, and safely disposed.

The most important components of the Removal and Treatment alternative are summarized in Figure 5.4 and briefly outlined below.

Fish: A Fishing Advisory/Restrictions would be promulgated by the Alaska State Department of Fish and Game warning residents that ingestion of more that 1 meal $(300 \mathrm{~g})$ of fish per year could pose an unacceptable health risk (>10 $0^{-6}$ excess cancers) and/or designate Garrison Slough as a Catchand-Release-Only. Once the concentration in the fish population is shown to have decreased to acceptable levels (due to removal of the PCBs and the natural death rate of the fish), the Fishing Advisory/Restriction would be lifted.

Sediment Removal and Treatment: The preponderance of PCB contamination would be removed by mechanically dredging lin combination with temporary damming and by-passing of the targeted dredging area) approximately 300 linear $m(1000 \mathrm{ft})$ of Garrison Slough immediately upstream of Arctic Avenue (Figure 5.4). This portion of the slough is estimated to contain $-80 \%$ of the mass of the PCB contamination. Thus, this action would meet the RAO for sediment.

Dredging activities would be performed in late summer when surface water flows are their lowest, and the groundwater table is near its deepest. Surface water would be routed around the targeted dredging area to reduce the potential for sediment resuspension and transport, and to reduce the amount of water picked up during the dredging operation. Two small temporary dams, one upstream and one downstream of the targeted dredging area, would be constructed. Water from the slough would be diverted around this portion of the slough using two $110 \mathrm{l} / \mathrm{s}(1700 \mathrm{gpm})$ pumps and $20 \mathrm{~cm}$ diam. ( 8 in.) PVC piping. A trackhoe would be used to excavate the sediment to a depth of approximately $0.6 \mathrm{~m}(2 \mathrm{ft})$ plus a $10 \%$ over dig. This process would produce an estimated $660 \mathrm{~m}^{3}$ ( $860 \mathrm{cu}$ yd) of dredge spoil which would be placed into dump trucks. Each truckload from the $>50 \mathrm{ppm}$ contamination zone would be sampled to determine its bulk concentration. 


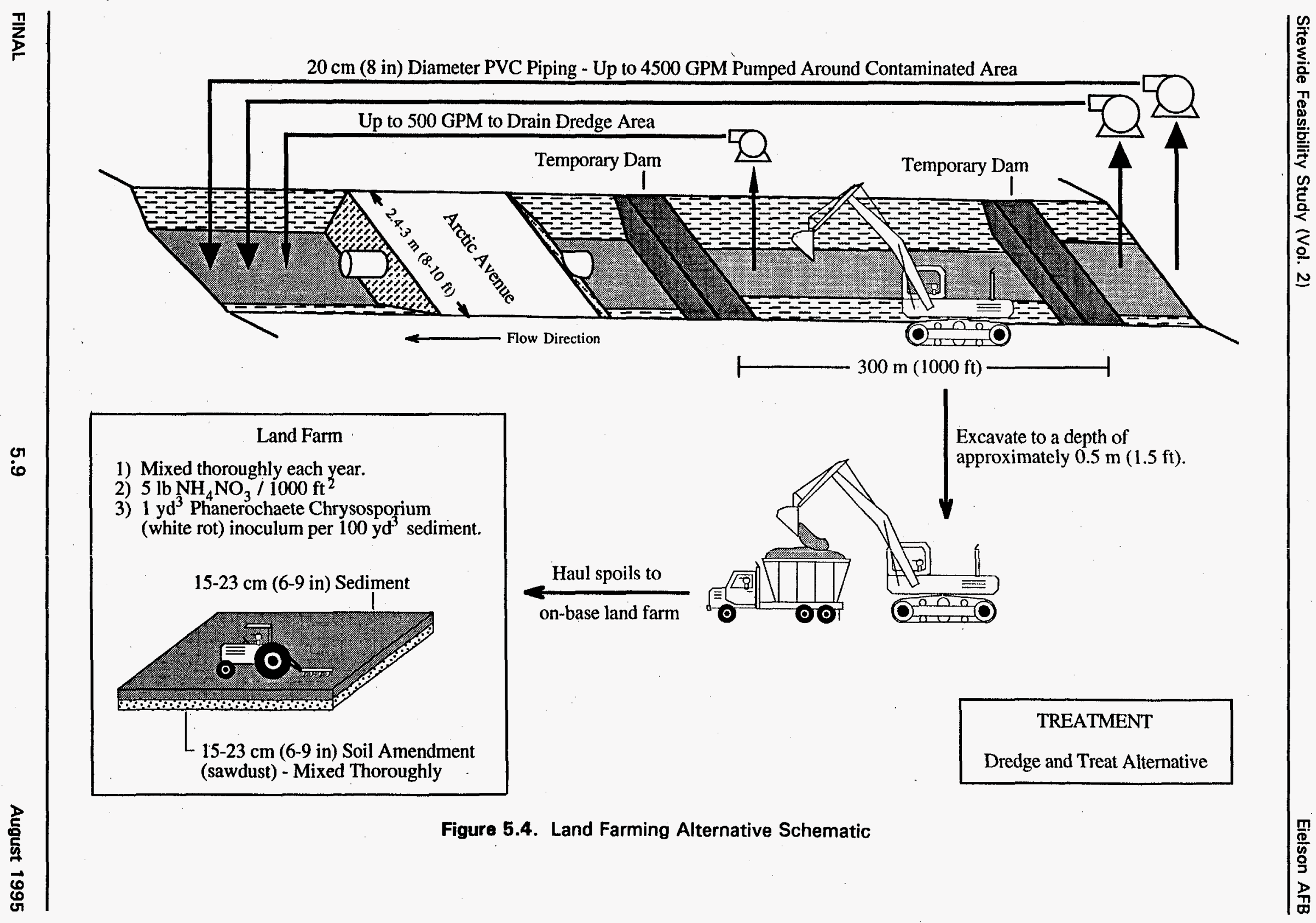


The dredged material would be hauled to an existing on-base land farming facility. Here the dredge material would be evenly spread over a $15 \mathrm{~cm}(6 \mathrm{in}$.) thick bed of soil amendments (that is, straw or sawdust) and inoculated with white rot fungus (Phanerocheate Chrysosporium) and nutrients. The sediment, soil amendments, and nutrients would then be tilled and evenly mixed. The addition of soil amendments is estimated to increase the volume of the waste materials by a factor of 2 .

Land farming would degrade the PCBs over several months to years (see Appendix A). The degradation might normally be complete in a season. However, due to the short growing season in this arctic region it is expected that up to three seasons may be required with new inoculations and aeration required at the beginning of each growing season. A treatability study would be conducted prior to full implementation to optimize the amounts and types of soil amendments and nutrients to be added.

\subsubsection{Summary of the Alternatives for Garrison Slough}

The primary components of each of the alternatives are summarized in Table 5.2.

Table 5.2. Primary Components in Alternatives for Garrison Slough

\begin{tabular}{||l|l|l||}
\hline \multicolumn{1}{|c|}{ Alternative } & \multicolumn{1}{|c|}{ Fish } & \multicolumn{1}{|c|}{ Sediment } \\
\hline \hline No Action & $\bullet$ No Action & $\bullet$ No Action \\
\hline Limited Action & $\bullet$ Fishing Restrictions \\
\hline In Situ Capping & $\bullet$ Fishing Restrictions & $\bullet$ No Action \\
\hline Dredge and Dispose & $\bullet \begin{array}{l}\bullet \text { Temporarily Divert Surface } \\
\text { Water } \\
\text { Line 300 m of Slough with a } \\
\text { Multilayer Cap }\end{array}$ \\
\hline Dredge and Treat & $\bullet$ Fishing Restrictions & $\begin{array}{l}\text { Temporarily Divert Surface } \\
\text { Water } \\
\text { Dredge 300 m of Slough } \\
\text { Dispose to On-base Landfill }\end{array}$ \\
\hline
\end{tabular}




\subsection{INDIVIDUAL EVALUATION OF ALTERNATIVES}

This section presents an analysis of each of the five alternatives for Garrison Slough described in Section 5.1. The alternatives are evaluated against the seven NCP criteria presented in Table 5.1. The analyses are presented in table format as indicated below:

Table 5.3 No Action

Table $5.4 \quad$ Limited Action

Table 5.5 In Situ Capping

Table 5.6 Dredge and Dispose

Table 5.7 Dredge and Treat

\subsection{COMPARATIVE EVALUATION OF ALTERNATIVES}

A comparative evaluation of the alternatives for Garrison Slough is provided in Table 5.8. The alternatives are compared based on how each alternative measures against the seven NCP criteria presented in Table 5.1. 
Table 5.3. Individual Analysis of the Garrison Slough No Action Alternative

\begin{tabular}{|c|c|}
\hline Criteria & Evaluation \\
\hline \multicolumn{2}{|c|}{ Overall Protection of Human Health and Emironment } \\
\hline Fish Ingestion for current users & No reduction in risk except by natural attenuation. \\
\hline Fish Ingestion for future users & No reduction in risk except by natural attenuation. \\
\hline \multicolumn{2}{|l|}{ Compliance with ARARs } \\
\hline Chemical Specific & Not Applicable \\
\hline Location Specific & $\begin{array}{l}\text { No action would be taken to restore and preserve the flood plain, } \\
\text { stream, and/or wetland area. }\end{array}$ \\
\hline Action Specific & Not Applicable \\
\hline \multicolumn{2}{|l|}{ Long Term Effectiveness and Permanence } \\
\hline Magnitude of residual risk & Risks will eventually be reduced through natural attenuation. \\
\hline Adequacy of reliable controls & No controls are provided. \\
\hline \multicolumn{2}{|l|}{ Reduction of Toxicity, Mobility, and Volume } \\
\hline $\begin{array}{l}\text { Treatment processes used and materials } \\
\text { treated }\end{array}$ & None. \\
\hline $\begin{array}{l}\text { Amount of hazardous material destroyed or } \\
\text { treated }\end{array}$ & None. \\
\hline $\begin{array}{l}\text { Expected reduction in toxicity, mobility, and } \\
\text { volume }\end{array}$ & None. \\
\hline Irreversibility of treatment & None. \\
\hline Type and quantity of treatment residual & None. \\
\hline \multicolumn{2}{|l|}{ Shortferm Effectiveness } \\
\hline $\begin{array}{l}\text { Protection of community during remedial. } \\
\text { action }\end{array}$ & No increased risk to community No remedial action taken. \\
\hline Protection of workers during remedial action & Not Applicable. \\
\hline Time until remedial objectives are achieved & $\begin{array}{l}\text { Fish and sediment remedial action objectives will not be achieved } \\
\text { through natural attenuation for } 10 \mathrm{~s} \text { to } 100 \mathrm{~s} \text { of years. }\end{array}$ \\
\hline Environmental impacts & $\begin{array}{l}\text { PCB contamination will continue to move through the ecosystem via } \\
\text { contaminated biota (including fish) and sediment. }\end{array}$ \\
\hline \multicolumn{2}{|l|}{ Implementability } \\
\hline $\begin{array}{l}\text { Technical feasibility of operation and } \\
\text { construction }\end{array}$ & Not Applicable. \\
\hline Reliability of technology & Not Applicable \\
\hline Availability of services and material & Not Applicable. \\
\hline Administrative feasibility & Acceptability to the community and regulatory agencies is uncertain. \\
\hline \multicolumn{2}{|l|}{ Cost } \\
\hline Capital & $\$ 0$ \\
\hline Annual $O \& M$ & \$o \\
\hline Annual Monitoring & $\$ 6,400$ \\
\hline Present Worth (5\%, 30 years) & $\$ 98,384$ \\
\hline
\end{tabular}


Table 5.4. Individual Analysis of the Garrison Slough Limited Action Alternative

\begin{tabular}{|c|c|}
\hline Individual Technical Components & Fishing Restrictions and Fish Control Dam \\
\hline Criteria & Evaluation \\
\hline \multicolumn{2}{|c|}{ Overall Protection of Human Health and Environment } \\
\hline Fish Ingestion for current users & $\begin{array}{l}\text { A Fish Advisory and Catch-and-Release fishing restrictions } \\
\text { would reduce the short-term risk to humans by preventing } \\
\text { the ingestion of potentially contaminated fish. }\end{array}$ \\
\hline Fish Ingestion for future users & $\begin{array}{l}\text { The fishing restrictions in conjunction with a fish control dam } \\
\text { would reduce the longer term risks, by preventing the } \\
\text { ingestion of fish, and by inhibiting the migration of fish into } \\
\text { the contaminated portion of the slough, thereby reducing } \\
\text { their bioaccumulation of PCBs. }\end{array}$ \\
\hline \multicolumn{2}{|l|}{ Compliance with ARARs } \\
\hline Chemical Specific & Not Applicable. \\
\hline Location Specific & $\begin{array}{l}\text { No long-term actions would be taken to minimize potential } \\
\text { harm and/or restore and preserve the flood plain, steam, } \\
\text { and/or wetland area. Installation of the fish control dam } \\
\text { would cause some impacts to Garrison Slough }\end{array}$ \\
\hline Action Specific & Not Applicable. \\
\hline \multicolumn{2}{|c|}{ Long Term Effectiveness and Permanence } \\
\hline Magnitude of residual risk & Risks may eventually be reduced through natural attenuation. \\
\hline Adequacy of reliable controls & $\begin{array}{l}\text { Promulgation of Catch-and-Release fishing restrictions is } \\
\text { expected to provide adequate controls to greatly reduce lif } \\
\text { not totally prevent) the ingestion of contaminated fish. } \\
\text { However, the adequacy of the fish control dam in preventing } \\
\text { the migration of fish into the contaminated portion of the } \\
\text { slough is uncertain. }\end{array}$ \\
\hline \multicolumn{2}{|c|}{ Reduction of Toxicity, Mobility, and Volume } \\
\hline $\begin{array}{l}\text { Treatment processes used and } \\
\text { materials treated }\end{array}$ & None. \\
\hline $\begin{array}{l}\text { Amount of hazardous material } \\
\text { destroyed or treated }\end{array}$ & None. \\
\hline $\begin{array}{l}\text { Expected reduction in toxicity, } \\
\text { mobility, and volume }\end{array}$ & None. \\
\hline Irreversibility of treatment & None. \\
\hline $\begin{array}{l}\text { Type and quantity of treatment } \\
\text { residual }\end{array}$ & None. \\
\hline
\end{tabular}


Table 5.4. (contd)

\begin{tabular}{|c|c|}
\hline Individual Technical Components: & Fishing Restrictions and Fish Control Dam \\
\hline Criteria & Evaluation \\
\hline \multicolumn{2}{|l|}{ Short-Term Effectiveness } \\
\hline $\begin{array}{l}\text { Protection of community during } \\
\text { remedial action }\end{array}$ & $\begin{array}{l}\text { The risk to the community should be greatly reduced } \\
\text { following promulgation of the Catch-and-Release fishing } \\
\text { restrictions. }\end{array}$ \\
\hline $\begin{array}{l}\text { Protection of workers during } \\
\text { remedial action }\end{array}$ & $\begin{array}{l}\text { Virtually no risk to workers as fish control dam would be } \\
\text { installed far enough downstream that PCB concentrations } \\
\text { pose virtually no risk. }\end{array}$ \\
\hline $\begin{array}{l}\text { Time until remedial objectives } \\
\text { are achieved }\end{array}$ & $\begin{array}{l}\text { The RAO for fish would be met shortly after promulgation of } \\
\text { the fishing restrictions; by cutting off the exposure route. } \\
\text { The sediment RAO would not be achieved through natural } \\
\text { attenuation for } 10 \text { s to } 100 \text { s of years. }\end{array}$ \\
\hline Environmental impacts & $\begin{array}{l}\text { PCB contamination would continue to move through the } \\
\text { ecosystem via contaminated biota (including fish) and } \\
\text { sediment. The fish control dam would raise the surface } \\
\text { water level behind the dam and would inhibit migrating fish } \\
\text { from reaching some spawning grounds. }\end{array}$ \\
\hline \multicolumn{2}{|l|}{ Implementability } \\
\hline $\begin{array}{l}\text { Technical feasibility of operation } \\
\text { and construction }\end{array}$ & $\begin{array}{l}\text { Promulgation of the fishing restrictions and installation of the } \\
\text { fish control dam are both implementable. Catch-and-Release } \\
\text { restrictions are already in place at Piledriver Slough. } \\
\text { Installation of the rock dam is not technically difficult. }\end{array}$ \\
\hline Reliability of technology & $\begin{array}{l}\text { The fishing restrictions are reliable, if not totally preventing } \\
\text { the ingestion of fish (due to poaching), at least greatly } \\
\text { reducing the potential. } \\
\text { The reliability of the fish control dam, however, is uncertain. }\end{array}$ \\
\hline $\begin{array}{l}\text { Availability of services and } \\
\text { material }\end{array}$ & $\begin{array}{l}\text { All necessary services and materials are available and easily } \\
\text { accessible. }\end{array}$ \\
\hline Administrative feasibility & $\begin{array}{l}\text { Acceptability to the community and regulatory agencies is } \\
\text { uncertain. }\end{array}$ \\
\hline \multicolumn{2}{|l|}{ Cost } \\
\hline Capital & $\$ 10,327$ \\
\hline Annual O \& M & $\$ 2,032$ \\
\hline Annual Monitoring & $\$ 6,400$ \\
\hline Present Worth $(5 \%, 30$ years) & $\$ 139,948$ \\
\hline
\end{tabular}


Table 5.5. Individual Analysis of the Garrison Slough In Situ Capping Alternative

\begin{tabular}{|c|c|}
\hline \multicolumn{2}{|c|}{$\begin{array}{l}\text { Individual Technical Components: Temporary fishing restrictions; temporary diversion of the } \\
\text { slough; and In Situ Capping (via multilayer barrier) of } \sim 80 \% \text { of the PCB contaminated sediment. }\end{array}$} \\
\hline Criteria & Evaluation \\
\hline \multicolumn{2}{|c|}{ Overall Protection of Human Health and Environment } \\
\hline Fish Ingestion for current users & $\begin{array}{l}\text { A Fish Advisory and/or Catch-and-Release fishing } \\
\text { restrictions would reduce the short-term risk to humans } \\
\text { by prevent the ingestion of potentially contaminated } \\
\text { fish. }\end{array}$ \\
\hline Fish Ingestion for future users & $\begin{array}{l}\text { Isolation of most PCBs should reduce their } \\
\text { bioaccumulation in fish thus, eventually reducing the } \\
\text { PCB concentration in the fish population; and thereby } \\
\text { reducing the human health risk due to ingestion. }\end{array}$ \\
\hline \multicolumn{2}{|l|}{ Compliance with ARARs } \\
\hline Chemical Specific & Not Applicable. \\
\hline Location Specific & $\begin{array}{l}\text { Remedial actions would be performed to minimize } \\
\text { potential harm and/or restore and preserve the flood } \\
\text { plain, steam, and/or wetland area. However, temporary } \\
\text { diversion of the surface water and installation of a liner } \\
\text { would cause some adverse impacts to a portion of } \\
\text { Garrison Slough }\end{array}$ \\
\hline Action Specific & Not Applicable. \\
\hline \multicolumn{2}{|c|}{ Long Term Effectiveness and Permanence } \\
\hline Magnitude of residual risk & $\begin{array}{l}\text { Risks may eventually be reduced through natural } \\
\text { attenuation. }\end{array}$ \\
\hline Adequacy of reliable controls & $\begin{array}{l}\text { The reliability of a permeable multilayer barrier to isolate } \\
\text { the PCBs in these sediments is good as long as the } \\
\text { integrity of the liner is not disrupted by vegetation or } \\
\text { other bioturbation, and/or is not disrupted by changing } \\
\text { stream flow conditions. Requires monitoring and } \\
\text { maintenance to preserve integrity of liner. }\end{array}$ \\
\hline \multicolumn{2}{|c|}{ Reduction of Toxicity, Mobility, and Volume } \\
\hline $\begin{array}{l}\text { Treatment processes used and } \\
\text { materials treated }\end{array}$ & None. \\
\hline $\begin{array}{l}\text { Amount of hazardous material } \\
\text { destroyed or treated }\end{array}$ & None. \\
\hline $\begin{array}{l}\text { Expected reduction in toxicity, } \\
\text { mobility, and volume }\end{array}$ & $\begin{array}{l}\text { Contaminants in fish and sediment may eventually be } \\
\text { dispersed and degraded below toxic levels through } \\
\text { natural processes. }\end{array}$ \\
\hline
\end{tabular}


Table 5.5. (contd)

\begin{tabular}{|c|c|}
\hline \multicolumn{2}{|c|}{$\begin{array}{l}\text { Individual Technical Components: Temporary fishing restrictions; temporary diversion of the } \\
\text { slough; and in Situ Capping (via multilayer barrier) of } \sim 80 \% \text { of the PCB contaminated sediment. }\end{array}$} \\
\hline Criteria & Evaluation \\
\hline Irreversibility of treatment & None. \\
\hline $\begin{array}{l}\text { Type and quantity of treatment } \\
\text { residual }\end{array}$ & None. \\
\hline \multicolumn{2}{|l|}{ Short-Term Effectiveness } \\
\hline $\begin{array}{l}\text { Protection of community during } \\
\text { remedial action }\end{array}$ & $\begin{array}{l}\text { The risk to the community should be greatly reduced } \\
\text { following promulgation of the Catch-and-Release fishing } \\
\text { restrictions. Resuspension and downstream migration } \\
\text { of contaminated sediments will be controlled by } \\
\text { isolating the construction area and diverting the surface } \\
\text { water. }\end{array}$ \\
\hline $\begin{array}{l}\text { Protection of workers during remedial } \\
\text { action }\end{array}$ & $\begin{array}{l}\text { Workers would be subjected to direct contact/exposure } \\
\text { to PCBs during installation and maintenance of the cap. }\end{array}$ \\
\hline $\begin{array}{l}\text { Time until remedial objectives are } \\
\text { achieved }\end{array}$ & $\begin{array}{l}\text { The RAO for fish would be met shortly after } \\
\text { promulgation of the fishing restrictions, by cutting off } \\
\text { the exposure route. The sediment RAO would be } \\
\text { achieved following installation of the surface cap. }\end{array}$ \\
\hline Environmental impacts & $\begin{array}{l}\text { Installation of the surface cap will essentially destroy } \\
\text { the existing stream bed and will raise it } 30 \text { to } 45 \mathrm{~cm} \text {. } \\
\text { This procedure will dramatically affect the ecology of } \\
\text { this portion of the slough for many years. }\end{array}$ \\
\hline \multicolumn{2}{|l|}{ Implementability } \\
\hline $\begin{array}{l}\text { Technical feasibility of operation and } \\
\text { construction }\end{array}$ & $\begin{array}{l}\text { Promulgation of Catch-and-Release restrictions is very } \\
\text { feasible and is already in place at Piledriver Slough. } \\
\text { Temporary damming and re-routing of the surface water } \\
\text { is also fairly easily implemented. However, installation } \\
\text { of the multilayer cap may be some what problematic in } \\
\text { that it may have to be installed through standing water } \\
\text { and over soft sediment. }\end{array}$ \\
\hline Reliability of technology & $\begin{array}{l}\text { The reliability of a permeable multilayer barrier to isolate } \\
\text { the PCBs in these sediments is good as long as the } \\
\text { integrity of the liner is not disrupted by vegetation or } \\
\text { other bioturbation, and/or is not disrupted by changing } \\
\text { stream flow conditions. }\end{array}$ \\
\hline Availability of services and material & $\begin{array}{l}\text { Materials are readily available. However, the availability } \\
\text { of qualified contractors to properly design and install } \\
\text { the cap is uncertain. }\end{array}$ \\
\hline
\end{tabular}


Table 5.5. (contd)

\begin{tabular}{|c|c|}
\hline \multicolumn{2}{|c|}{$\begin{array}{l}\text { Individual Technical Components: Temporary fishing restrictions; temporary diversion of the } \\
\text { slough; and In Situ Capping (via multilayer barrier) of } \sim 80 \% \text { of the PCB contaminated sediment. }\end{array}$} \\
\hline Criteria & Evaluation \\
\hline Administrative feasibility & $\begin{array}{l}\text { Acceptability to the community and regulatory agencies } \\
\text { is uncertain. }\end{array}$ \\
\hline \multicolumn{2}{|l|}{ Cost } \\
\hline Capital & $\$ 182,086$ \\
\hline Annual $O \& M$ & $\$ 2,132$ \\
\hline Annual Monitoring & $\$ 6,400$ \\
\hline Present Worth (5\%, 30 years) & $\$ 290,080$ \\
\hline
\end{tabular}


Table 5.6. Individual Analysis of the Garrison Slough Dredge and Dispose Alternative

\begin{tabular}{|c|c|}
\hline \multicolumn{2}{|c|}{$\begin{array}{l}\text { Individual Technical Components: Temporary fishing restrictions; temporary diversion of the } \\
\text { slough; dredging of } \sim 80 \% \text { of the PCBs in contaminated sediment; and on-base disposal. }\end{array}$} \\
\hline Criteria & Evaluation \\
\hline \multicolumn{2}{|c|}{ Overall Protection of Human Health and Environment } \\
\hline Fish Ingestion for current users & $\begin{array}{l}\text { Catch-and-Release fishing restrictions would reduce the } \\
\text { short term risk to humans by prevent the ingestion of } \\
\text { potentially contaminated fish. }\end{array}$ \\
\hline Fish Ingestion for future users & $\begin{array}{l}\text { Removal of most PCBs should reduce their bioaccumulation } \\
\text { in fish, thus eventually reducing the PCB concentration in the } \\
\text { fish population; and thereby reducing the human health risk } \\
\text { due to ingestion. }\end{array}$ \\
\hline \multicolumn{2}{|l|}{ Compliance with ARARs } \\
\hline Chemical Specific & Not Applicable. \\
\hline Location Specific & $\begin{array}{l}\text { Remedial actions would be performed to minimize potential } \\
\text { harm and/or restore and preserve the flood plain, steam, } \\
\text { and/or wetland area. However, temporary diversion of the } \\
\text { surface water and dredging activities would cause some } \\
\text { adverse impacts to a portion of Garrison Slough. Remedial } \\
\text { actions would have to minimize these effects and protect } \\
\text { the fish and wildlife. }\end{array}$ \\
\hline Action Specific & $\begin{array}{l}\text { Requires EPA approval for alternate disposal of dredge } \\
\text { materials } \geq 50 \mathrm{ppm} \text {. }\end{array}$ \\
\hline \multicolumn{2}{|c|}{ Long Term Effectiveness and Permanence } \\
\hline Magnitude of residual risk & $\begin{array}{l}\text { Approximately } 20 \% \text { of the PCB contamination lin low } \\
\text { concentrations }(<10 \mathrm{ppm})] \text { will be left in place. The risks } \\
\text { from this residual contamination may eventually be reduced } \\
\text { through natural attenuation. }\end{array}$ \\
\hline Adequacy of reliable controls & $\begin{array}{l}\text { The removal of PCBs from the slough is a very reliable way } \\
\text { to control the contamination. }\end{array}$ \\
\hline \multicolumn{2}{|c|}{ Reduction of Toxicity, Mobility, and Volume } \\
\hline $\begin{array}{l}\text { Treatment processes used and } \\
\text { materials treated }\end{array}$ & None. \\
\hline $\begin{array}{l}\text { Amount of hazardous material } \\
\text { destroyed or treated }\end{array}$ & None. \\
\hline $\begin{array}{l}\text { Expected reduction in toxicity, } \\
\text { mobility, and volume }\end{array}$ & $\begin{array}{l}\text { Approximately } 80 \% \text { of the PCB contamination would be } \\
\text { removed from the slough. Natural attenuation should } \\
\text { reduce the PCB contamination in the fish population. }\end{array}$ \\
\hline Irreversibility of treatment & None. \\
\hline
\end{tabular}


Table 5.6. (contd)

\begin{tabular}{|c|c|}
\hline \multicolumn{2}{|c|}{$\begin{array}{l}\text { Individual Technical Components: Temporary fishing restrictions; temporary diversion of the } \\
\text { slough; dredging of } \sim 80 \% \text { of the PCBs in contaminated sediment; and on-base disposal. }\end{array}$} \\
\hline Criteria & Evaluation \\
\hline $\begin{array}{l}\text { Type and quantity of treatment } \\
\text { residual }\end{array}$ & None. \\
\hline \multicolumn{2}{|l|}{ Short-Term Effectiveness } \\
\hline $\begin{array}{l}\text { Protection of community during } \\
\text { remedial action }\end{array}$ & $\begin{array}{l}\text { The risk to the community should be greatly reduced } \\
\text { following promulgation of the Catch-and-Release fishing } \\
\text { restrictions. Resusperision and downstream migration of } \\
\text { contaminated sediments during dredging will be controlled } \\
\text { by isolating the area and diverting the surface water. }\end{array}$ \\
\hline $\begin{array}{l}\text { Protection of workers during } \\
\text { remedial action }\end{array}$ & $\begin{array}{l}\text { Workers would be subjected to direct contact and exposure } \\
\text { to PCBs during dredging, transportation, and treatment. } \\
\text { Some increased worker risk due to the used of heavy } \\
\text { equipment. }\end{array}$ \\
\hline $\begin{array}{l}\text { Time until remedial objectives are } \\
\text { achieved }\end{array}$ & $\begin{array}{l}\text { The RAO for fish would be met shortly after promulgation of } \\
\text { the fishing restrictions, by cutting off the exposure route. } \\
\text { The sediment RAO would be achieved when dredging was } \\
\text { complete. }\end{array}$ \\
\hline Environmental impacts & $\begin{array}{l}\text { Dredging will essentially destroy the existing stream bed and } \\
\text { will lower its base level } 30 \text { to } 60 \mathrm{~cm} \text {. This will dramatically } \\
\text { affect the ecology of this portion of the slough for many } \\
\text { years. And will result in some short term water quality } \\
\text { impacts (eg turbidity) as the stream bed re-equilibrates. } \\
\text { It should be noted that this portion of the slough channel is } \\
\text { man made, and a significant portion of the surface water } \\
\text { flow is a result of discharges from the base Water } \\
\text { Treatment Plant. }\end{array}$ \\
\hline
\end{tabular}


Table 5.6. (contd)

\begin{tabular}{|c|c|}
\hline \multicolumn{2}{|c|}{$\begin{array}{l}\text { Individual Technical Components: Temporary fishing restrictions; temporary diversion of the } \\
\text { slough; dredging of }-80 \% \text { of the PCBs in contaminated sediment; and on-base disposal. }\end{array}$} \\
\hline Criteria & Evaluation \\
\hline \multicolumn{2}{|l|}{ Implementability } \\
\hline $\begin{array}{l}\text { Technical feasibility of operation } \\
\text { and construction }\end{array}$ & $\begin{array}{l}\text { Promulgation of Catch-and-Release restrictions is very } \\
\text { feasible and is already in place at Pile Driver Slough. } \\
\text { Temporary damming and re-routing of the surface water is } \\
\text { also fairly easily implemented. Dredging and on-site } \\
\text { disposal is straight forward and should present no problems. }\end{array}$ \\
\hline Reliability of technology & $\begin{array}{l}\text { Dredging and disposal of PCB contaminated sediment is } \\
\text { proven technology, and has been selected as the preferred } \\
\text { remedial action alternative in the RODs of many superfund } \\
\text { sites. }\end{array}$ \\
\hline $\begin{array}{l}\text { Availability of services and } \\
\text { material }\end{array}$ & $\begin{array}{l}\text { Dredging and hauling service are readily available in both } \\
\text { the local and regional area. }\end{array}$ \\
\hline Administrative feasibility & $\begin{array}{l}\text { Acceptability to the community and regulatory agencies is } \\
\text { uncertain. }\end{array}$ \\
\hline \multicolumn{2}{|l|}{ Cost } \\
\hline Capital & $\$ 163,826$ \\
\hline Annual O \& $M$ & $\$ 0$ \\
\hline Annual Monitoring & $\$ 6,400^{(a)}$ \\
\hline Present Worth (5\%, 30 years) & $\$ 190,979$ \\
\hline
\end{tabular}


Table 5.7. Individual Analysis of the Garrison Slough Dredge and Treat Alternative

\begin{tabular}{|c|c|}
\hline Criteria & Evaluation \\
\hline \multicolumn{2}{|c|}{ Overall Protection of Human Health and Environment } \\
\hline Fish Ingestion for current users & $\begin{array}{l}\text { Catch-and-Release fishing restrictions would reduce the } \\
\text { short term risk to humans by preventing the ingestion of } \\
\text { potentially contaminated fish. }\end{array}$ \\
\hline Fish Ingestion for future users & $\begin{array}{l}\text { Removal of most PCBs should reduce their bioaccumulation } \\
\text { in fish thus eventually reducing the PCB concentration in the } \\
\text { fish population; and there by reducing the human health risk } \\
\text { due to ingestion. }\end{array}$ \\
\hline \multicolumn{2}{|l|}{ Compliance with ARARs } \\
\hline Chemical-Specific & Not Applicable. \\
\hline Location-Specific & $\begin{array}{l}\text { Remedial actions would be performed to minimize potential } \\
\text { harm and/or restore and preserve the flood plain, steam, } \\
\text { and/or wetland area. However, temporary diversion of the } \\
\text { surface water and dredging activities would cause some } \\
\text { adverse impacts to a portion of Garrison Slough. Remedial } \\
\text { actions would have to minimize these effects and protect } \\
\text { the fish and wildlife. }\end{array}$ \\
\hline Action-Specific & $\begin{array}{l}\text { Must demonstrate performance equivalent to incineration by } \\
\text { showing that solid residuals contain less or equal to } 2 \mathrm{ppm} \\
\text { PCBs (EPA 1990). }\end{array}$ \\
\hline \multicolumn{2}{|c|}{ Long-Term Effectiveness and Permanence } \\
\hline Magnitude of residual risk & $\begin{array}{l}\text { Approximately } 20 \% \text { of the PCB contamination lin low } \\
\text { concentrations }(<10 \mathrm{ppm}) \text { l will be left in place. The risks } \\
\text { from this residual contamination may eventually be reduced } \\
\text { through natural attenuation. }\end{array}$ \\
\hline Adequacy of reliable controls & $\begin{array}{l}\text { The removal of PCBs from the slough is a very reliable way } \\
\text { to control the contamination. }\end{array}$ \\
\hline \multicolumn{2}{|c|}{ Reduction of Toxicity, Mobility, and Volume } \\
\hline $\begin{array}{l}\text { Treatment processes used and } \\
\text { materials treated }\end{array}$ & $\begin{array}{l}\text { Bioremediation via land farming (using sawdust, white rot } \\
\text { fungus, and nutrients) would be used to treat approximately } \\
660 \mathrm{~m}^{3}(860 \mathrm{cu} \text { yd) of dredge spoils containing }-80 \% \text { of } \\
\text { the PCB contamination. }\end{array}$ \\
\hline $\begin{array}{l}\text { Amount of hazardous material } \\
\text { destroyed or treated }\end{array}$ & $\begin{array}{l}\text { An estimated } 27 \mathrm{~kg} \text { of PCBs would be removed in the } \\
660 \mathrm{~m}^{3} \text { of sediment dredged from the slough. Land farming } \\
\text { would dehalogenate greater than } 91 \% \text { of these PCBs, } \\
\text { leaving a residual concentration of }<2 \mathrm{ppm} \text { (see } \\
\text { Appendix A). }\end{array}$ \\
\hline $\begin{array}{l}\text { Expected reduction in toxicity, } \\
\text { mobility, and volume }\end{array}$ & $\begin{array}{l}\text { Approximately } 80 \% \text { of the PCB contamination would be } \\
\text { removed from the slough. And greater than } 91 \% \text { of the } \\
\text { PCBs removed would be destroyed. }\end{array}$ \\
\hline
\end{tabular}


Table 5.7. (contd)

\begin{tabular}{|c|c|}
\hline \multicolumn{2}{|c|}{$\begin{array}{l}\text { Individual Technical Components: Temporary fishing restrictions; temporary diversion of the } \\
\text { slough; dredging of } \sim 80 \% \text { of the PCBs in contaminated sediment; and land farming treatment. }\end{array}$} \\
\hline$\overline{\text { Criteria }}$ & Evaluation \\
\hline Irreversibility of treatment & $\begin{array}{l}\text { The treatment is not reversible. Once dehalogenated the } \\
\text { residual compounds would remain stable. }\end{array}$ \\
\hline $\begin{array}{l}\text { Type and quantity of treatment } \\
\text { residual }\end{array}$ & $\begin{array}{l}\text { The residual would primarily consist of the degraded } \\
\text { sediment and soil amendments with PCB concentrations } \\
<2 \mathrm{ppm} \text {. The estimated quantity would be approximately } \\
1300 \mathrm{~m}^{3}(1700 \mathrm{cu} \text { yd). }\end{array}$ \\
\hline \multicolumn{2}{|l|}{ Short-Term Effectiveness } \\
\hline $\begin{array}{l}\text { Protection of community during } \\
\text { remedial action }\end{array}$ & $\begin{array}{l}\text { The risk to the community should be greatly reduced } \\
\text { following promulgation of the Catch-and-Release fishing } \\
\text { restrictions. Resuspension and downstream migration of } \\
\text { contaminated sediments during dredging will be controlled } \\
\text { by isolating the area and diverting the surface water. } \\
\text { Institutional controls would prevent direct contact during the } \\
\text { land farming treatment. }\end{array}$ \\
\hline $\begin{array}{l}\text { Protection of workers during } \\
\text { remedial action }\end{array}$ & $\begin{array}{l}\text { Workers would be subjected to direct contact and exposure } \\
\text { to PCBs during dredging, transportation, and treatment. } \\
\text { Some increased worker risk due to the use of heavy } \\
\text { equipment. }\end{array}$ \\
\hline $\begin{array}{l}\text { Time until remedial objectives are } \\
\text { achieved }\end{array}$ & $\begin{array}{l}\text { The RAO for fish would be met shortly after promulgation of } \\
\text { the fishing restrictions, by cutting off the exposure route. } \\
\text { The sediment RAO would be achieved when dredging was } \\
\text { complete. }\end{array}$ \\
\hline Environmental impacts & $\begin{array}{l}\text { Dredging will essentially destroy the existing stream bed and } \\
\text { will lower its base level } 30 \text { to } 60 \mathrm{~cm} \text {. This procedure will } \\
\text { dramatically affect the ecology of this portion of the slough } \\
\text { for many years. It may result in some short-term water } \\
\text { quality impacts (such as, turbidity) as the stream bed re- } \\
\text { equilibrates. }\end{array}$ \\
\hline
\end{tabular}


Table 5.7. (contd)

\begin{tabular}{|c|c|}
\hline$\overline{\text { Criteria }}$ & $\overline{\text { Evaluation }}$ \\
\hline \multicolumn{2}{|l|}{ Implementability } \\
\hline $\begin{array}{l}\text { Technical feasibility of operation } \\
\text { and construction }\end{array}$ & $\begin{array}{l}\text { Promulgation of Catch-and-Release restrictions is very } \\
\text { feasible and is already in place at Pile Driver Slough. } \\
\text { Temporary damming, re-routing of the surface water, and } \\
\text { dredging are straightforward and fairly easily implemented. } \\
\text { Land farming practices are also easily implemented and } \\
\text { were recently demonstrated at Eielson. }\end{array}$ \\
\hline Reliability of technology & $\begin{array}{l}\text { Biodegradation of PCBs via land farming, particularly with } \\
\text { the highly chlorinated heavy congeners, such as those } \\
\text { found in Aroclor } 1260 \text {, and in an Arctic environment, is not } \\
\text { well established. Some treatability testing should be } \\
\text { performed. }\end{array}$ \\
\hline $\begin{array}{l}\text { Availability of services and } \\
\text { material }\end{array}$ & $\begin{array}{l}\text { Dredging and hauling services are readily available in both } \\
\text { the local and regional area. Land farming facilities are also } \\
\text { present at Eielson. Inoculum would be shipped from Utah. }\end{array}$ \\
\hline Administrative feasibility & $\begin{array}{l}\text { Acceptability to the community and regulatory agencies is } \\
\text { uncertain. }\end{array}$ \\
\hline \multicolumn{2}{|l|}{ Cost } \\
\hline Capital & $\$ 138,743$ \\
\hline Annual O \& M & $\$ 18,700^{(0)}$ \\
\hline Annual Monitoring & $\$ 6,400^{(b)}$ \\
\hline Present Worth $(5 \%, 30$ years) & $\$ 216,821$ \\
\hline
\end{tabular}


Table 5.8. Comparative Analysis of the Garrison Slough Alternatives

\begin{tabular}{|c|c|}
\hline Criteria & Evaluation \\
\hline \multicolumn{2}{|c|}{ Overall Protection of Human Health and Environment } \\
\hline $\begin{array}{l}\text { Fish Ingestion for } \\
\text { current users }\end{array}$ & $\begin{array}{l}\text { The NO ACTION alternative relies on eventual natural attenuation. } \\
\text { The LIMITED ACTION alternative uses permanent fishing restrictions } \\
\text { to prevent the ingestion of fish. } \\
\text { All others use temporary fishing restrictions. }\end{array}$ \\
\hline $\begin{array}{l}\text { Fish Ingestion for } \\
\text { future users }\end{array}$ & $\begin{array}{l}\text { NO ACTION and LIMITED ACTION alternatives rely on natural } \\
\text { attenuation. } \\
\text { All others either isolate or remove most PCBs from possible } \\
\text { bioaccumulation, there by reducing the PCB concentration in the fish } \\
\text { population and the human health risk due to ingestion. }\end{array}$ \\
\hline \multicolumn{2}{|c|}{ Compliance with ARARs } \\
\hline Chemical-Specific & Not Applicable. \\
\hline Location Specific & $\begin{array}{l}\text { Neither the NO ACTION nor LIMITED ACTION alternative take direct } \\
\text { action to minimize the potential harm and/or protect the fish and } \\
\text { wildlife in this stream/wetland area. } \\
\text { In addition, the rock dam used in the LIMITED ACTION alternative } \\
\text { would inhibit the migration of fish and remove much of the slough } \\
\text { from spawning grounds for an indefinite period of time. } \\
\text { The IN SITU CAPPING and REMOVAL alternatives would cause some } \\
\text { dramatic effects to the slough bottom and entire ecosystem in the } \\
\text { disturbed area. However, these impacts should be relatively short- } \\
\text { lived (within a few years). }\end{array}$ \\
\hline Action-Specific & $\begin{array}{l}\text { Not Applicable for NO ACTION, LIMITED ACTION, or IN SITU } \\
\text { CAPPING. }\end{array}$ \\
\hline
\end{tabular}


- Table 5.8. (contd)

\begin{tabular}{|c|c|}
\hline Criteria & Evaluation \\
\hline \multicolumn{2}{|c|}{ Long-Term Effectiveness and Permanence } \\
\hline $\begin{array}{l}\text { Magnitude of } \\
\text { residual risk }\end{array}$ & $\begin{array}{l}\text { The NO ACTION, LIMITED ACTION, and IN SITU CAPPING } \\
\text { alternatives leave all of the contamination in place. } \\
\text { However, the IN SITU CAPPING alternative isolates all but }-20 \% \text { of } \\
\text { the contamination from the ecosystem. } \\
\text { Both removal alternatives (ON BASE DISPOSAL and EX-SITU } \\
\text { TREATMENT) leave } 20 \% \text { of the FCB contamination lin low } \\
\text { concentrations ( }<10 \mathrm{ppm} \text { ) in place. The risks from this residual } \\
\text { contamination may eventually be reduced through natural attenuation. } \\
\text { The DREDGE AND DISPOSE alternative would comply with TSCA for } \\
\text { dredged material (EPA } 1990 \text { ). The DREDGE AND TREAT alternative } \\
\text { would comply with TSCA if it can be shown that the residual PCB } \\
\text { concentrations would be } \leq 2 \mathrm{ppm} \text { (EPA 1990). }\end{array}$ \\
\hline $\begin{array}{l}\text { Adequacy of reliable } \\
\text { controls }\end{array}$ & $\begin{array}{l}\text { The NO ACTION alternative provides no reliable controls. } \\
\text { All other alternatives provide good controls for preventing the } \\
\text { ingestion of potentially contaminated fish. } \\
\text { However, the LIMITED ACTION alternative provides little control for } \\
\text { isolating the PCB contaminated sediment from the ecosystem and fish } \\
\text { population. } \\
\text { The IN SITU CAPPING alternative isolates } 80 \% \text { of the contamination. } \\
\text { Long-term reliability requires monitoring and maintenance to preserve } \\
\text { integrity of liner. } \\
\text { The two removal alternatives ensure a very high degree of reliability to } \\
\text { isolate the contamination from the ecosystem of the slough. }\end{array}$ \\
\hline \multicolumn{2}{|c|}{ Reduction of Toxicity, Mobility, and Volume } \\
\hline $\begin{array}{l}\text { Treatment } \\
\text { processes used and } \\
\text { materials treated }\end{array}$ & $\begin{array}{l}\text { Only the DREDGE AND TREAT alternative uses a treatment process. } \\
\text { Treatment would be accomplished via land farming. An estimated } \\
660 \mathrm{~m}^{3} \text { ( } 860 \mathrm{cu} \text { yd) of dredge spoils, containing } \sim 80 \% \text { of the PCB } \\
\text { contamination, would be treated. }\end{array}$ \\
\hline $\begin{array}{l}\text { Amount of } \\
\text { hazardous material } \\
\text { destroyed or treated }\end{array}$ & $\begin{array}{l}\text { Only the DREDGE AND TREAT alternative would treat the PCB } \\
\text { contamination. Greater than } 25 \mathrm{~kg}(55 \mathrm{lb}) \text { of the estimated } 27 \mathrm{~kg} \\
(60 \mathrm{lb})(93 \%) \text { of PCBs removed would be dehalogenated, leaving a } \\
\text { residual concentration of }<2 \mathrm{ppm} \text {. }\end{array}$ \\
\hline $\begin{array}{l}\text { Expected reduction } \\
\text { in toxicity, mobility, } \\
\text { and volume }\end{array}$ & $\begin{array}{l}\text { Only the DREDGE AND TREAT alternative would reduce the PCB } \\
\text { contamination through treatment. Permanent reduction of the toxicity } \\
\text { is estimated at }>91 \% \text { of the PCBs removed from the slough. }\end{array}$ \\
\hline
\end{tabular}


Table 5.8. (contd)

\begin{tabular}{|c|c|c|c|c|}
\hline Criteria & \multicolumn{4}{|c|}{ Evaluation } \\
\hline $\begin{array}{l}\text { Irreversibility of } \\
\text { treatment }\end{array}$ & \multicolumn{4}{|c|}{$\begin{array}{l}\text { Only the DREDGE AND TREAT alternative treats the contamination. } \\
\text { This treatment is not reversible. Once dehalogenated, the residual } \\
\text { compounds would remain stable. }\end{array}$} \\
\hline $\begin{array}{l}\text { Type and quantity } \\
\text { of treatment } \\
\text { residual }\end{array}$ & \multicolumn{4}{|c|}{$\begin{array}{l}\text { Only the DREDGE AND TREAT alternative leaves are treatment } \\
\text { residual. This residual would consist of the degraded sediment and } \\
\text { soil amendments with PCB concentrations }<2 \mathrm{ppm} \text {. The estimated } \\
\text { quantity of the residual would be approximately } 1300 \mathrm{~m}^{3} \\
(1700 \mathrm{cu} \text { yd). }\end{array}$} \\
\hline \multicolumn{5}{|c|}{ Short-Term Effectiveness } \\
\hline $\begin{array}{l}\text { Protection of } \\
\text { community during } \\
\text { remedial action }\end{array}$ & \multicolumn{4}{|c|}{$\begin{array}{l}\text { The NO ACTION alternative would neither increase nor decrease the } \\
\text { risk to the community. } \\
\text { All other alternatives would reduce the risk to the community through } \\
\text { promulgation of the Catch-and-Release fishing restrictions. } \\
\text { The IN SITU CAPPING, and dredging alternatives present the potential } \\
\text { for some resuspension and downstream migration of contaminated } \\
\text { sediments, which would be controlled by isolating the area and } \\
\text { diverting the surface water. } \\
\text { The DREDGE AND TREAT alternative presents some potential for } \\
\text { direct contact exposure during land farming. Institutional controls } \\
\text { would mitigate this potential. }\end{array}$} \\
\hline $\begin{array}{l}\text { Protection of } \\
\text { workers during } \\
\text { remedial action }\end{array}$ & \multicolumn{4}{|c|}{$\begin{array}{l}\text { The NO ACTION and LIMITED ACTION alternatives present no risk to } \\
\text { workers. } \\
\text { The remaining alternatives would subject workers to direct contact } \\
\text { and exposure to PCBs during installation of the cap, dredging, } \\
\text { transportation, and/or treatment. They would also present some } \\
\text { increased risk due to the use of heavy equipment. }\end{array}$} \\
\hline $\begin{array}{l}\text { Time until remedial } \\
\text { objectives are } \\
\text { achieved }\end{array}$ & $\begin{array}{l} \\
\text { NO ACTION } \\
\text { LIMITED ACTION } \\
\text { IN SITU CAPPING } \\
\text { DREDGE AND DISPOSE } \\
\text { DREDGE AND TREAT }\end{array}$ & $\begin{array}{l}\text { Prevent Ingestion } \\
\text { of Fish } \\
\text { Tens of years. } \\
\text { A few weeks. } \\
\text { A few weeks. } \\
\text { A few weeks. } \\
\text { A few weeks. }\end{array}$ & $\begin{array}{c}\text { Reduce Fish Tissue } \\
\text { Concentrations } \\
\text { Tens of years. } \\
\text { 8-10 years. } \\
\text { 8-10 years. } \\
\text { 8-10 years. } \\
\text { 8-10 years. }\end{array}$ & $\begin{array}{l}\text { Sediment } \\
\text { Tens of years. } \\
\text { Tens of years. } \\
\text { A few weeks. } \\
\text { A few weeks. } \\
\text { A few weeks. }\end{array}$ \\
\hline
\end{tabular}


Table 5.8. (contd)

\begin{tabular}{|l|l||}
\hline \multicolumn{1}{|c|}{ Criteria } & \multicolumn{1}{c|}{ Evaluation } \\
\hline \hline & $\begin{array}{l}\text { The NO ACTION and LIMITED ACTION alternatives would allow PCB } \\
\text { contamination to continue to move through the ecosystem. } \\
\text { In addition, the LIMITED ACTION alternative would raise the base level of the } \\
\text { slough behind the rock dam, and inhibit migrating fish from reaching spawning } \\
\text { grounds. } \\
\text { The remaining alternatives will essentially destroy } 300 \mathrm{~m} \text { (1000 ft) of the } \\
\text { existing channel and dramatically affect the ecology of the slough over the } \\
\text { area subjected to remediation. } \\
\text { IN SITU CAPPING will also raise the bottom 30 to 45 cm (1 to 1.5 ft), and } \\
\text { continued maintenance of the liner may continue to adversely affect the } \\
\text { slough. } \\
\text { The DREDGING alternatives will lower the bed of the slough approximately } \\
\text { 6O cm (2 ft) and some short-term degradation of the surface water (turbidity) } \\
\text { may occur. However, the slough is expected to fully recover within a few } \\
\text { years. }\end{array}$ \\
\hline $\begin{array}{ll}\text { Implementability } \\
\text { Operation and } \\
\text { construction }\end{array}$ & $\begin{array}{l}\text { The NO ACTION alternative is the most easily implemented. } \\
\text { Promulgation of Catch-and-Release restrictions in the remaining alternatives is } \\
\text { feasible and is already in place at Pile Driver Slough. } \\
\text { Temporary damming and rerouting of the surface water is fairly } \\
\text { straightforward and easily implemented. } \\
\text { IN SITU CAPPING may be some what problematic if installed through standing } \\
\text { water and/or over soft sediment. } \\
\text { DREDGING and ON-SITE DISPOSAL is straightforward and the preferred } \\
\text { remedial action at many sites. } \\
\text { LAND FARMING TREATMENT practices are easily implemented and have been } \\
\text { demonstrated at Eielson AFB. }\end{array}$ \\
\hline
\end{tabular}


Table 5.8. (contd)

\begin{tabular}{|c|c|c|}
\hline Criteria & \multicolumn{2}{|c|}{ Evaluation } \\
\hline $\begin{array}{l}\text { Reliability of } \\
\text { technology }\end{array}$ & \multicolumn{2}{|c|}{$\begin{array}{l}\text { Fishing restrictions are reliable for preventing the ingestion of fish; if not } \\
\text { totally (due to poaching), then at least for greatly reducing the potential. } \\
\text { The reliability of the fish control dam used in the LIMITED ACTION alternative } \\
\text { is uncertain. } \\
\text { The reliability of IN SITU CAPPING is good as long as the integrity of the liner } \\
\text { is not disrupted via bioturbation or changing stream flow conditions. } \\
\text { DREDGING AND DISPOSAL of PCB contaminated sediment is proven } \\
\text { technology, and has been selected as the preferred remedial action alternative } \\
\text { in the RODs of many Superfund sites. } \\
\text { BIOLOGICAL TREATMENT of PCBs via land farming, particularly with the } \\
\text { highly chlorinated heavy congeners, such as those found in Aroclor } 1260 \text {, and } \\
\text { in an arctic environment, is not well established. Some treatability testing } \\
\text { should be performed. }\end{array}$} \\
\hline $\begin{array}{l}\text { Availability of services } \\
\text { and material }\end{array}$ & \multicolumn{2}{|c|}{$\begin{array}{l}\text { All service and materials are readily available and accessible. } \\
\text { However the availability of qualified contractors to install the IN SITU } \\
\text { CAPPING is uncertain. } \\
\text { The availability of an existing landfill at Eielson for the DISPOSAL alternative } \\
\text { is uncertain. } \\
\text { The availability of the existing land farming facilities at Eielson for the } \\
\text { TREATMENT alternative is also some what uncertain. The white rot fungus } \\
\text { inoculum would be shipped in from Utah. }\end{array}$} \\
\hline $\begin{array}{l}\text { Administrative } \\
\text { feasibility }\end{array}$ & \multicolumn{2}{|c|}{$\begin{array}{l}\text { The acceptability to the community and regulatory agencies for any of these } \\
\text { alternatives is uncertain. }\end{array}$} \\
\hline \multicolumn{3}{|l|}{ Cost } \\
\hline Capital & $\begin{array}{l}\text { NO ACTION } \\
\text { LIMITED ACTION } \\
\text { IN SITU CAPPING } \\
\text { DREDGE AND DISPOSE } \\
\text { DREDGE AND TREAT }\end{array}$ & $\begin{array}{r}\$ 0 \\
\$ 10,327 \\
\$ 182,086 \\
\$ 164,826 \\
\$ 138,743\end{array}$ \\
\hline Annual $O \& M$ & $\begin{array}{l}\text { NO ACTION } \\
\text { LIMITED ACTION } \\
\text { IN SITU CAPPING } \\
\text { DREDGE AND DISPOSE } \\
\text { DREDGE AND TREAT }\end{array}$ & $\begin{array}{r}\$ 0 \\
\$ 2,032 \\
\$ 2,132 \\
\$ 0 \\
\$ 18,700^{(0)}\end{array}$ \\
\hline Annual Monnitoring & $\begin{array}{l}\text { NO ACTION } \\
\text { LIMITED ACTION } \\
\text { IN SITU CAPPING } \\
\text { DREDGE AND DISPOSE } \\
\text { DREDGE AND TREAT }\end{array}$ & $\begin{array}{l}\$ 6,400 \\
\$ 6,400 \\
\$ 6,400 \\
\$ 6,400^{(b)} \\
\$ 6,400^{(b)}\end{array}$ \\
\hline
\end{tabular}


Table 5.8. (contd)

\begin{tabular}{||l|lr|}
\hline \multicolumn{1}{|c|}{ Criteria } & \multicolumn{2}{|c|}{ Evaluation } \\
\hline \hline Present Worth (5\%, & NO ACTION & $\$ 98,384$ \\
30 years) & LIMITED ACTION & $\$ 139,948$ \\
& IN SITU CAPPING & $\$ 290,080$ \\
& DREDGE AND DISPOSE & $\$ 190,979$ \\
& DREDGE AND TREAT & $\$ 216,821$ \\
\hline \hline (a) Drops to \$0 after 3 years. & \\
(b) Drops to $\$ 6000$ after 3 years, and \$0 after 8 years. \\
\hline
\end{tabular}




\subsection{REFERENCES}

Bender. 1993. Biological Effects of Cultured Cyanobacteria Mats on Water Contaminants. Report \#1 to the U.S. Environmental Protection Agency, Grant \#CR8168901.

Boeve, L. 1989. "Removing Petroleum Products from Soils with Ozone, Ultraviolet, Ultrasonics and Ultrapure Water", In Petroleum Contaminated Soils. Volume 2: Remediation Techniques,

Environmental Fate, Risk Assessment, Analytical Methodologies. P. 279-282. Lewis Publishers, Chelsea, Michigan.

De Boer, J., F. V. Valk, M.A.T. Kerkhoff, P. Hage, U.A.T. Brinkman. 1994. "8-Year Study of the Elimination of PCBs and Other Organochlorine Compounds from Eel (Anguilla anguilla) Under Natural Conditions", In Environmental Science and Technology; Vol. 28, No. 13, p. 2242-2248.

Harding Lawson Associates (HLA). 1991. Installation Restoration Program Remedial Investigation/Feasibility Study, Stage 4. Draft Report for Eielson Air Force Base, Fairbanks, Alaska, Volume IV, Draft Remedial Investigation/Feasibility Study. Prepared by Harding Lawson Associates for the Alaska Air Command, Elmendorf Air Force Base, Alaska.

Harkeness, M. R., J. B. McDermott, D. A. Abromowicz, J. J. Salvo, W. P. Flanagan, M. L. Stephans, F. J. Mondello, R. F. May, J. H. Lobos, K. M. Carroll, M. J. Brennan, A. A. Bracco, K. M. Fish, G. L. Warner, P. R. Wilson, D. K. Dietrch, D. T. Lin, C. B. Morgan, and W. L. Gately. 1993. "In Situ Stimulation of Aerobic PCB Biodegradation in Hudson River Sediments", In Science; Vol. 259, p. 503-507.

Pacific Northwest Laboratory (PNL). 1993a. Site Management Plan, Eie/son Air Force Base, Alaska. Prepared by the Pacific Northwest Laboratory, Richland, Washington, for the U.S. Air Force, Eielson Air Force Base, Environmental Restoration Program, Fairbanks, Alaska.

Pacific Northwest Laboratory (PNL). 1993b. Automatic Water-Level Measurements, Eielson Air Force Base, Alaska, September 1991 - August 1992. Prepared by the Pacific Northwest Laboratory, Richland, Washington, for the U.S. Air Force, Eielson Air Force Base, Environmental Restoration Program, Fairbanks, Alaska.

Rhee, G. Y., R. C. Sokol, B. Bush, and C., M. Bethoney. 1993. "Long-Term Study of the Anaerobic Dechlorination of Arochlor 1254 with and without Biphenyl Enrichment", In Environmental Science Technology; Vol. 27, No. 4, p. 714-719. American Chemical Society.

U.S. Air Force (USAF). 1992. Background Ground-Water Quality, Eie/son Air Force Base, Alaska. U.S. Air Force Environmental Restoration Program, Eielson Air Force Base, Fairbanks, Alaska.

U.S. Air Force (USAF). 1994a. Screening Baseline Risk Assessment, Sitewide. Draft. Prepared by the Pacific Northwest Laboratory, Richland, Washington, for the U.S. Air Force, Eielson Air Force Base, Fairbanks, Alaska.

U.S. Air Force (USAF). 1994b. Eielson Air Force Base OU-3, 4, and 5 Remedial Investigation/Feasibility Study: Baseline Risk Assessment. Prepared by the Pacific Northwest, Laboratory, Richland, Washington, for the U.S. Air Force, Eielson Air Force Base, Fairbanks, Alaska. 
U.S. Air Force (USAF). 1994c. 1993 Sitewide Groundwater Monitoring Report. Prepared by the Pacific Northwest Laboratory, Richland, Washington, for the U.S. Air Force, Eielson Air Force Base, Fairbanks, Alaska.

U.S. Air Force (USAF). 1994d. Surface Water and Sediment Investigation, Draft Report, Eie/son Air Force Base, Alaska. Prepared by the Pacific Northwest Laboratory, Richland, Washington, for the U.S. Air Force, Eielson Air Force Base, Fairbanks, Alaska.

U.S. Air Force (USAF). 1995a. United States Air Force Environmental Restoration Program Eie/son Air Force Base, Alaska, Sitewide Remedial Investigation Report. Prepared by the Pacific Northwest Laboratory, Richland, Washington, for the U.S. Air Force, Eielson Air Force Base, Fairbanks, Alaska.

U.S. Air Force (USAF). 1995b. United States Air Force Environmental Restoration Program Eie/san Air Force Base, Alaska, Sitewide Base Line Risk Assessment Report. Prepared by the Pacific Northwest Laboratory, Richland, Washington, for the U.S. Air Force, Eielson Air Force Base, Fairbanks, Alaska.

U.S. Air Force (USAF). 1995c. 1994 Sitewide Groundwater Monitoring Report. Prepared by the Pacific Northwest Laboratory, Richland, Washington, for the U.S. Air Force, Eielson Air Force Base, Fairbanks, Alaska.

U.S. Air Force (USAF). 1995d. Eielson Air Force Base. Sitewide Remedial Investigation/Feasibility Study-Biological Risk Assessment. Prepared by the Pacific Northwest Laboratory, Richland, Washington, for the U.S. Air Force, Eielson Air Force Base, Fairbanks, Alaska.

U.S. Environmental Protection Agency (EPA). 1990. Guidance on Remedial Actions for Superfund Sites with PCB Contamination. PB91-921206. Office of Emergency and Remedial Response, U.S. Environmental Protection Agency, Washington, D.C.

White, M. K., and J. L. Bryant. 1993. ReOpt ${ }^{T M}$ Vol. 2.1. PNL-7840, Rev. 1, Pacific Northwest Laboratory, Richland, Washington. 


\section{APPENDIX A}

\section{ASSUMPTIONS AND CALCULATIONS USED IN THE DEVELOPMENT AND EVALUATION OF ALTIERNATIVES}


Sitewide Feasibility Study (Vol. 2)

Eielson AFB

CONTENTS

A. 1 NO ACTION ALTERNATIVE

A.2 LIMITED ACTION ALTERNATIVE

A.2.1 Fishing Advisory/Restrictions

A.2.2 Rock Dam

A.3 IN SITU CAPPING ALTERNATIVE

A.3.1 PCB Mass Estimates from Garrison Slough

A.3.2 Temporary Diversion of Surface Water

A.3.3 Installation of Liner
A.3

A.4

A. 4

A.4

A. 4

A. 5

A.5

A.11

A. 12

A. 12

A. 12

A. 12

A. 12

A. 13

A. 13

FINAL

A. 1

August 1995 


\section{FIGURE}

A.1 Location of 1994 and 1995 Garrison Slough sediment sampling locations _. . . A.6

\section{TABLES}

A.1 Aroclor 1260 concentrations in 1994 and 1995 sediment samples from Garrison Slough . . . . . . . .

A.2 PCB Mass Estimates $\ldots \ldots \ldots \ldots \ldots \ldots \ldots \ldots \ldots \ldots \ldots \ldots \ldots \ldots \ldots$

A.3 Depth and Description of Slough Sediment near Artic

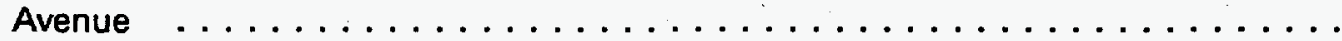




\section{APPENDIX A \\ ASSUMPTIONS AND CALCULATIONS USED IN THE DEVELOPMENT AND EVALUATION OF ALTERNATIVES}

This appendix provides backup information relevant to the development and analysis of the alternatives for Garrison Slough presented in Section 5 . It briefly identifies the technical assumptions, methodologies used in making preliminary calculations, input parameters for the hydrogeological modeling, and other relevant information.

The appendix is comprised of six sections. Section A.1 describes the assumptions used in the development of the No Action alternative. Section A.2 describes the assumption used in development of the Limited Action alternative. Section A.3 describes the assumptions and calculations used in developing the In Situ Capping alternative. Section A.4 describes the assumptions and calculations used in developing the Dredge and Dispose alternative. Section A.5 describes the assumptions and calculations used in developing the DREDGE AND TREAT alternative.

\section{A.1 NO ACTION ALTERNATIVE}

Without any remedial action, it was estimated that tens of years may be required to naturally degrade the PCBs to meeting the RAOs for both fish and sediment. However, it is extremely difficult to predict the time required for natural attenuation of PCBs in aquatic sediment due to the variation in behavior between various congeners and the variability in site specific environmental factors.

Estimate of Natural Degradations. Harkness et al. (1993) reiterate that PCBs can undergo biodegradation both anaerobically and aerobically. Anaerobic bacteria typically attack higher chlorinated $\mathrm{PCB}$ congeners through reductive dechlorination. This process removes chlorines, but leaves the biphenyl rings intact, and results in a corresponding increase in lower chlorinated congeners. Aerobic bacteria can degrade the lower chlorinated PCB congeners through oxidative degradation, producing the corresponding chlorobenzoic acids, which are readily degraded by other aerobic bacteria.

Rhee et al. (1993) reported that dechlorination of PCBs in anaerobic environments is generally considered to be slow, with major changes not observed for months or years. The results of their study reconfirmed that dechlorination was congener-specific and affected by sediment conditions. Thus, in situ dechlorination in contaminated sediments can be understood only through direct investigation of in-place congeners in their own sediments.

Because of these uncertainties, the estimated time frame to achieve the RAOs for sediment through natural attenuation was assumed to take at least an order of magnitude longer than the time required using an active land farming treatment system. The time required for $\mathrm{PCB}$ degradation through land farming with active inoculation of white rot fungus, soil amendments, and nutrient additions, was estimated to range from 1 to 3 years. Using the order of magnitude assumption, it may take more than 10 to 30 years to sufficiently reduce PCB concentrations in aquatic sediments to meet the RAOs ( $\sim 80 \%$ reduction) by natural attenuation. 
Natural attenuation in fish is estimated to be longer than the natural life span of the fish ( -8 years). De Boer et al. (1994) found that the half-life of PCBs in eels under natural conditions ranged from 340 days to over 8 years, with half-life proportional to the number of chlorine atoms, and with the primary change due to growth dilution.

\section{A.2 LIMITED ACTION ALTERNATIVE}

The Limited Action alternative would use a Fish Advisory and/or Catch-and-Release fishing restrictions to limit current and future exposures to contaminated fish, and a rock dam to inhibit the migration of fish into the source area for the PCBs. The Limited Action alternative relies on natural attenuation to reduce their concentration in sediment and fish over time (see Section A.1).

\section{A.2.1 Fishing Advisory/Restrictions}

It was assumed that any Fish Advisory and/or Catch-and-Release restrictions would be promulgated by the Alaska State Department of Fish and Game. The fishing advisory would state that ingestion of more than 1 meal ( $\geq 300 \mathrm{~g}$ ) of fish per year from Garrison Slough may pose an undue health risk and should be avoided. This number of fish meals was back calculated using a human health risk threshold of $10^{-6}$ excess cancers in the recreational exposure scenario (USAF 1995b).

It was also assumed that designation of Garrison Slough as a Catch-and-Release-only area (in spite of poaching) would essentially prevent the ingestion of contaminated fish.

\section{A.2.2 Rock Dam}

If properly designed, a rock dam can severely inhibit, if not prevent, the migration of fish into the contaminated portion of the slough. A sufficient height for a dam, to present a severe obstacle to Grayling fish (estimated to ránge up to $45 \mathrm{~cm}$ [18 in.] in length) was estimated to be approximately 1 meter $(3.3 \mathrm{ft})$.

The slope of the channel was estimated from the difference in staff gauge readings at Central avenue and Arctic Avenue. The difference in July and October, 1992 observations was $2.14 \mathrm{~m}$ ( $7 \mathrm{ft}$ ) (USAF 1995a). The distance between gauging stations is approximately $2.23 \mathrm{~km}(7300 \mathrm{ft})$. This figure results in a grade of approximately $1 \mathrm{~m} / \mathrm{km}(1 \mathrm{ft} / 1000 \mathrm{ft})$. Thus, a $1-\mathrm{m}$ rock dam could back water up the slough to a distance of approximately $1 \mathrm{~km}$.

\section{A.3 IN SITU CAPPING ALTERNATIVE}

The In Situ Capping alternative consists of temporary Fishing Advisory/Restrictions as discussed in Section A.2 and a multilayer cap to isolate the majority of the PCBs in sediment from the ecosystem. Approximately $240 \mathrm{~m}$ of Garrison Slough just upstream of Arctic Avenue would be lined with a multilayer cap to isolate a preponderance of the PCB-contaminated sediment from the ecosystem. This portion of the slough contains $\sim 80 \%$ of the mass of the PCB contamination, and thus would meet the RAO. 


\section{A.3.1 PCB Mass Estimates from Garrison Slough}

The mass of PCBs found in Garrison Slough was estimated using both the August/September 1994 sediment analyses as well as a recent (May, 1995) set of sediment screening analyses ${ }^{\left({ }^{(a)}\right.}$. These two data sets were combined and organized in a spread sheet with distances relative to the location of sampling station GSOO (Figure A.1). These data are provided in Table A.1.

The slough was divided into segments surrounding each sample location. The length of each segment $\left(L_{s}\right)$ was taken as the distance between the midpoints between the designated sampling location and its upstream and downstream neighbors. The Aroclor 1260 concentration at that sampling location was used as the average concentration (C) for that segment in the mass balance estimates. These estimates assume that the slough was 3.3 meters $(10 \mathrm{ft})$ wide $\left(W_{\mathrm{s}}\right)$, and that contamination was evenly spread to a depth $\left(D_{s}\right)$ of $0.6 \mathrm{~m}(2 \mathrm{ft})$. The bulk density $(\mathrm{pb})$ of the sediment was assumed to be $1.8 \mathrm{~g} / \mathrm{cc}\left(3000 \mathrm{lbs} / \mathrm{yd}^{3}\right)$. The mass for each segment was then calculated as follows:

$$
\begin{aligned}
& \text { MPCB }(\mathrm{kg})=C(\mu \mathrm{g} / \mathrm{kg}) * M S(\mathrm{~kg}) \\
& \operatorname{MPCB}(\mathrm{kg})=C(\mu \mathrm{g} / \mathrm{kg}) / 10 E 9(\mu \mathrm{g} / \mathrm{kg}) *\left(L_{s} * W_{S} * D_{S}\right)\left(\mathrm{m}^{3}\right) * \rho b(\mathrm{~kg} / \mathrm{m} 3)
\end{aligned}
$$

The cumulative mass percent was calculated by summing (from upstream to downstream) the PCB mass in each segment, and then dividing this sum by the total estimated PCB mass. Table A.2 presents the mass estimates for each segment and the cumulative percent mass. Note that for this evaluation those analyses that were reported to be less than the detection limit, were taken as zero.

These results indicate that the portion of the slough considered to be the principal threat (from just upstream of sampling station GS41 to Arctic Avenue (just downstream from station GS25), accounts for about $81 \%$ of the total PCB mass present in Garrison Slough.

\section{A.3.2 Temporary Diversion of Surface Water}

Capping would be performed in late summer when surface water flows are their lowest, and the groundwater table is near its deepest. Surface water would be routed around the capping area to reduce the potential for sediment resuspension and transport, and to make installation of the liner less complicated. Two small temporary dams, one upstream and one downstream of the targeted dredging area, would be constructed. Water from the slough would be diverted around this portion of the slough using two diesel-powered pumps and $20 \mathrm{~cm}$ dia. (8-in.) PVC piping. A third pump would be used to dewater the now isolated portion of the slough in preparation for capping.

(a) Personal communication with Steve McNeil, Eielson Air Force Base, via telephone and fax, on May 17 and 18; and with Patricia White, Pacific Northwest Laboratory, via express mail on May 19, and via electronic mail (for distances) on May 23, 1995. 


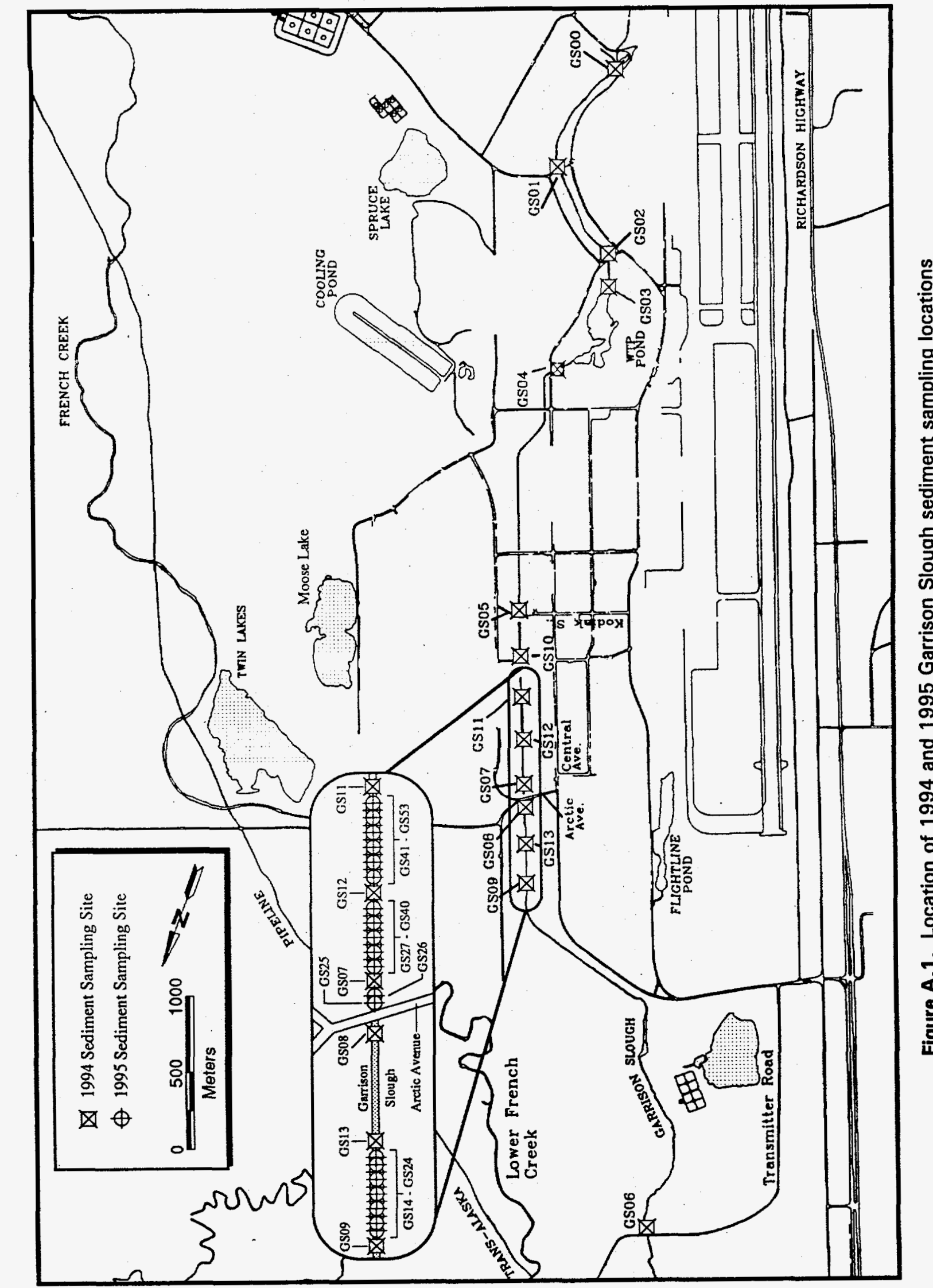


Table A.1. Aroclor 1260 concentrations in 1994 and 1995 sediment samples from Garrison Slough.

\begin{tabular}{|c|c|c|c|}
\hline Station ID & Distance from GSOO (ft) & Distance from GSOO (m) & Aroclor $1260(\mu \mathrm{g} / \mathrm{kg})$ \\
\hline GSOO & 0 & 0 & $<13$ \\
\hline GS01 & 1691 & 515 & $<13$ \\
\hline GSO3 & 3588 & 1094 & $<13$ \\
\hline GSO4 & 5466 & 1666 & $<13$ \\
\hline Gs05 & 9585 & 2922 & $<13$ \\
\hline GS10 & 10279 & 3133 & $<18$ \\
\hline GS11 & 10956 & 3339 & $<29$ \\
\hline GS53 & 11006 & 3355 & $<38$ \\
\hline GS52 & 11056 & 3370 & $<36$ \\
\hline GS51 & 11106 & 3385 & $<33$ \\
\hline GS50 & 11156 & 3400 & $<40$ \\
\hline GS49 & 11206 & 3416 & $<40$ \\
\hline GS48 & 11256 & 3431 & $<49$ \\
\hline GS47 & 11306 & 3446 & $<24$ \\
\hline GS46 & 11356 & 3461 & $<38$ \\
\hline GS45 & 11406 & 3477 & $<53$ \\
\hline GS44 & 11456 & 3492 & $<51$ \\
\hline GS43 & 11506 & 3507 & $<47$ \\
\hline GS42 & 11556 & 3522 & $<62$ \\
\hline GS41 & 11606 & 3538 & 52300 \\
\hline GS12 & 11656 & 3553 & 55000 \\
\hline GS40 & 11706 & 3568 & 65600 \\
\hline GS39 & 11756 & 3583 & 40200 \\
\hline GS38 & 11806 & 3598 & 42400 \\
\hline GS37 & 11856 & 3614 & 22100 \\
\hline GS36 & 11906 & 3629 & 32400 \\
\hline GS35 & 11956 & 3644 & 28000 \\
\hline GS34 & 12006 & 3659 & 24800 \\
\hline GS34(D) & 12006 & 3659 & 19600 \\
\hline GS33 & 12056 & 3675 & 23300 \\
\hline GS32 & 12106 & 3690 & 17700 \\
\hline GS31 & 12156 & 3705 & 24700 \\
\hline
\end{tabular}


Table A.1. (contd)

\begin{tabular}{|c|c|c|c|}
\hline Station ID & Distance from GSOO (ft) & Distance from GSOO (m) & Aroclor $1260(\mu \mathrm{g} / \mathrm{kg})$ \\
\hline GS30 & 12206 & 3720 & 18300 \\
\hline GS29 & 12256 & 3736 & 9820 \\
\hline GS28 & 1.2306 & 3751 & 6510 \\
\hline GS27 & 12406 & 3781 & 5880 \\
\hline GSO7 & 12431 & 3789 & 3200 \\
\hline GS26 & 12456 & 3797 & 5220 \\
\hline GS25 & 12506 & 3812 & 6050 \\
\hline GS08 & 12643 & 3854 & 2100 \\
\hline GS13 & 13366 & 4071 & 3500 \\
\hline GS24 & 13406 & 4086 & 5290 \\
\hline GS23 & 13456 & 4101 & 91.10 \\
\hline GS22 & 13506 & 4117 & 5290 \\
\hline GS21 & 13556 & 4132 & 7940 \\
\hline GS20 & 13606 & 4147 & 7620 \\
\hline GS19 & 13656 & 4162 & 6030 \\
\hline GS18 & 13706 & 4178 & 1370 \\
\hline GS17 & 13756 & 4193 & 3240 \\
\hline GS16 & 13806 & 4208 & 658 \\
\hline GS15 & 13856 & 4223 & 1370 \\
\hline GS14 & 13906 & 4239 & 1430 \\
\hline GS14 (D) & 13906 & 4239 & 741 \\
\hline GSO9 & 13941 & 4249 & 130 \\
\hline GS06 & 20568 & 6269 & 230 \\
\hline
\end{tabular}


Table A.2. PCB Mass Estimates.

\begin{tabular}{|c|c|c|c|c|c|c|c|}
\hline Station ID & $\begin{array}{c}\text { Aroclor } \\
1260 \text { (C) } \\
(\mu \mathrm{g} / \mathrm{kg})\end{array}$ & $\begin{array}{l}\text { Segment } \\
\text { Length, } L_{s} \\
\text { (m) }\end{array}$ & $\begin{array}{l}\text { Segment } \\
\text { Width, } W_{s} \\
\text { (m) }\end{array}$ & $\begin{array}{l}\text { Segment } \\
\text { Depth, } D_{s} \\
\text { (m) }\end{array}$ & $\begin{array}{l}\text { Mass of } \\
\text { Sediment } \\
\text { (kg) }\end{array}$ & $\begin{array}{c}\text { Mass PCB } \\
(\mathrm{kg})\end{array}$ & $\begin{array}{l}\text { Cumulative } \\
\text { Mass (\%) }\end{array}$ \\
\hline GSOO & $<13$ & 258 & 3.3 & 0.6 & 918473 & 0.00 & $0 \%$ \\
\hline GSO1 & $<13$ & 547 & 3.3 & 0.6 & 1948835 & 0.00 & $0 \%$ \\
\hline GSO3 & $<13$ & 575 & 3.3 & 0.6 & 2050405 & 0.00 & $0 \%$ \\
\hline GSO4 & $<13$ & 914 & 3.3 & 0.6 & 3257292 & 0.00 & $0 \%$ \\
\hline GSO5 & $<13$ & 734 & 3.3 & 0.6 & 2614198 & 0.00 & $0 \%$ \\
\hline GS10 & $<18$ & 209 & 3.3 & 0.6 & 744664 & 0.00 & $0 \%$ \\
\hline GS11 & $<29$ & 111 & 3.3 & 0.6 & 394873 & 0.00 & $0 \%$ \\
\hline GS53 & $<38$ & 15 & 3.3 & 0.6 & 54315 & 0.00 & $0 \%$ \\
\hline GS52 & $<36$ & 15 & 3.3 & 0.6 & 54315 & 0.00 & $0 \%$ \\
\hline GS51 & $<33$ & 15 & 3.3 & 0.6 & 54315 & 0.00 & $0 \%$ \\
\hline GS50 & $<40$ & 15 & 3.3 & 0.6 & 54315 & 0.00 & $0 \%$ \\
\hline GS49 & $<40$ & 15 & 3.3 & 0.6 & 54315 & 0.00 & $0 \%$ \\
\hline GS48 & $<49$ & 15 & 3.3 & 0.6 & 54315 & 0.00 & $0 \%$ \\
\hline GS47 & $<24$ & 15 & 3.3 & 0.6 & 54315 & 0.00 & $0 \%$ \\
\hline GS46 & $<38$ & 15 & 3.3 & 0.6 & 54315 & 0.00 & $0 \%$ \\
\hline GS45 & $<53$ & 15 & 3.3 & 0.6 & 54315 & 0.00 & $0 \%$ \\
\hline GS44 & $<51$ & 15 & 3.3 & 0.6 & 54315 & 0.00 & $0 \%$ \\
\hline GS43 & $<47$ & 15 & 3.3 & 0.6 & 54315 & 0.00 & $0 \%$ \\
\hline GS42 & $<62$ & 15 & 3.3 & 0.6 & 54315 & 0.00 & $0 \%$ \\
\hline GS41 & 52300 & 15 & 3.3 & 0.6 & 54315 & 2.84 & $9 \%$ \\
\hline GS12 & 55000 & 15 & 3.3 & 0.6 & 54315 & 2.99 & $18 \%$ \\
\hline GS40 & 65600 & 15 & 3.3 & 0.6 & 54315 & 3.56 & $28 \%$ \\
\hline GS39 & 40200 & 15 & 3.3 & 0.6 & 54315 & 2.18 & $35 \%$ \\
\hline GS38 & 42400 & 15 & 3.3 & 0.6 & 54315 & 2.30 & $42 \%$ \\
\hline GS37 & 22100 & 15 & 3.3 & 0.6 & 54315 & 1.20 & $46 \%$ \\
\hline GS36 & 32400 & 15 & 3.3 & 0.6 & 54315 & 1.76 & $51 \%$ \\
\hline GS35 & 28000 & 15 & 3.3 & 0.6 & 54315 & 1.52 & $56 \%$ \\
\hline GS34 & 24800 & 15 & 3.3 & 0.6 & 54315 & 1.35 & $60 \%$ \\
\hline GS34(D) & 19600 & \multicolumn{6}{|c|}{ NA } \\
\hline GS33 & 23300 & 15 & 3.3 & 0.6 & 54315 & 1.27 & $63 \%$ \\
\hline GS32 & 17700 & 15 & 3.3 & 0.6 & 54315 & 0.96 & $66 \%$ \\
\hline GS31 & 24700 & 15 & 3.3 & 0.6 & 54315 & 1.34 & $70 \%$ \\
\hline
\end{tabular}


Table A.2. (contd)

\begin{tabular}{|c|c|c|c|c|c|c|c|}
\hline Station ID & $\begin{array}{c}\text { Aroclor } \\
1260(\mathrm{C}) \\
(\mu \mathrm{g} / \mathrm{kg})\end{array}$ & $\begin{array}{l}\text { Segment } \\
\text { Length, } L_{s} \\
\text { (m) }\end{array}$ & $\begin{array}{c}\text { Segment } \\
\text { Width, } W_{s} \\
\text { (m) }\end{array}$ & $\begin{array}{c}\text { Segment } \\
\text { Depth, } D_{s} \\
\text { (m) }\end{array}$ & $\begin{array}{c}\text { Mass of } \\
\text { Sediment } \\
(\mathrm{kg})\end{array}$ & $\begin{array}{c}\text { Mass PCB } \\
(\mathbf{k g})\end{array}$ & $\begin{array}{l}\text { Cumulative } \\
\text { Mass (\%) }\end{array}$ \\
\hline GS3O & 18300 & 15 & 3.3 & 0.6 & 54315 & 0.99 & $73 \%$ \\
\hline GS29 & 9820 & 15 & 3.3 & 0.6 & 54315 & 0.53 & $75 \%$ \\
\hline GS28 & 6510 & 23 & 3.3 & 0.6 & 81473 & 0.53 & $77 \%$ \\
\hline GS27 & 5880 & 19 & 3.3 & 0.6 & 67894 & 0.40 & $78 \%$ \\
\hline GSO7 & 3200 & 8 & 3.3 & 0.6 & 27158 & 0.09 & $78 \%$ \\
\hline GS26 & 5220 & 11 & 3.3 & 0.6 & 40737 & 0.21 & $79 \%$ \\
\hline GS25 & 6050 & 28 & 3.3 & 0.6 & 101570 & 0.61 & $81 \%$ \\
\hline GSO8 & 2100 & 130 & 3.3 & 0.6 & 461681 & 0.97 & $84 \%$ \\
\hline GS13 & 3500 & 116 & 3.3 & 0.6 & 414426 & 1.45 & $88 \%$ \\
\hline GS24 & 5290 & 15 & 3.3 & 0.6 & 54315 & 0.29 & $89 \%$ \\
\hline GS23 & 9110 & 15 & 3.3 & 0.6 & 54315 & 0.49 & $90 \%$ \\
\hline GS22 & 5290 & 15 & 3.3 & 0.6 & 54315 & 0.29 & $91 \%$ \\
\hline GS21 & 7940 & 15 & 3.3 & 0.6 & 54315 & 0.43 & $93 \%$ \\
\hline GS20 & 7620 & 15 & 3.3 & 0.6 & 54315 & 0.41 & $94 \%$ \\
\hline GS19 & 6030 & 15 & 3.3 & 0.6 & 54315 & 0.33 & $95 \%$ \\
\hline GS18 & 1370 & 15 & 3.3 & 0.6 & 54315 & 0.07 & $95 \%$ \\
\hline GS17 & 3240 & 15 & 3.3 & 0.6 & 54315 & 0.18 & $96 \%$ \\
\hline GS16 & 658 & 15 & 3.3 & 0.6 & 54315 & 0.04 & $96 \%$ \\
\hline GS15 & 1370 & 15 & 3.3 & 0.6 & 54315 & 0.07 & $96 \%$ \\
\hline GS14 & 1430 & 13 & 3.3 & 0.6 & 46168 & 0.07 & $96 \%$ \\
\hline GS14 (D) & 741 & \multicolumn{6}{|c|}{ NA } \\
\hline GSO9 & 130 & 1015 & 3.3 & 0.6 & 3618489 & 0.47 & $97 \%$ \\
\hline GSO6 & 230 & 1010 & 3.3 & 0.6 & 3599479 & 0.83 & $100 \%$ \\
\hline Total & & & & & & 33.03 & \\
\hline
\end{tabular}


Estimated Stream Flow. HLA (1989) reported the stream near Arctic Avenue to be 2.4 to $3 \mathrm{~m}$ $(8-10 \mathrm{ft})$ wide and containing 0.3 to $0.6 \mathrm{~m}(1-2 \mathrm{ft})$ of water. In August, 1987, they estimated the flow velocity at 0.3 to $1.6 \mathrm{~m} / \mathrm{s}(1-5 \mathrm{ft} / \mathrm{s})$ and a flow rate of 0.14 to $0.28 \mathrm{~m}^{3} / \mathrm{s}(5$ to $10 \mathrm{cfs})$.

Observations during the August, 1994 sampling effort, indicated water velocities were on the order of 0.16 to $0.25 \mathrm{~m} / \mathrm{s}(0.5$ to $0.75 \mathrm{ft} / \mathrm{s}$ ) at stations GS08 and GS07, respectively (USAF 1995a) (see Table A.3). Given the previous channel width and depth estimates, this yields an estimated flow rate of 0.1 to $0.3 \mathrm{~m}^{3} / \mathrm{s}$ (4 to $10 \mathrm{cfs}$ ); consistent with HLA (1989) estimates.

Maximum flow in the slough occurs in April and.May. Water elevations measured at the gauging station near Arctic Avenue in 1991-92 show an increase in the water level of approximately $0.3 \mathrm{~m}$ between August and May. Using the maximum flow velocity of $1.6 \mathrm{~m} / \mathrm{s}(5 \mathrm{ft} / \mathrm{s})$, the maximum channel width of $3 \mathrm{~m}(10 \mathrm{ft})$, and maximum water depth of $1 \mathrm{~m}(3 \mathrm{ft})$, yields a maximum flow rate of $4.25 \mathrm{~m} 3 / \mathrm{s}(150 \mathrm{cfs})$.

\section{A.3.3 Installation of Liner}

It is assumed that only minimal preparation of the slough stream bed (devegetation and contouring) will be required. A permeable geotextile liner would then be installed, and covered by successive 10-15 cm (4-6 in.) thick layers of pea gravel; $5 \mathrm{~cm}$ dia. very coarse pebble (2-in. drain rock), and finally 5 to $15 \mathrm{~cm}$ dia. small cobble $(2-6$ in. rock). The use of a permeable liner was selected to permit any gases formed during decomposition of organic mater to escape and not lift the liner. The complete liner is estimated to raise the bed of the slough 30 to $45 \mathrm{~cm}$ (12 to $18 \mathrm{in}$.).

Table A.3. Depth and Description of Slough Sediment near Arctic Avenue

\begin{tabular}{|c|c|c|c|c|}
\hline $\begin{array}{l}\text { Sample } \\
\text { Station }\end{array}$ & $\begin{array}{l}\text { Water } \\
\text { Depth } \\
\left(\mathrm{cm}^{(\infty)}\right)\end{array}$ & $\begin{array}{l}\text { Flow } \\
\text { Velocity } \\
(\mathrm{m} / \mathrm{s})\end{array}$ & $\begin{array}{l}\text { Sediment } \\
\text { Depth } \\
\text { (cm) }\end{array}$ & Sediment Description \\
\hline $\begin{array}{c}\text { GS11 } \\
\text { (upstream) }\end{array}$ & $\begin{array}{l}\leq 30 \\
(1 \mathrm{ft})\end{array}$ & - & $\begin{array}{l}30 \\
(1 \mathrm{ft})\end{array}$ & $\begin{array}{l}\text { Very sticky much, very soft, greenish } \\
\text { brown, fine sand/silt/clay, a lot of } \\
\text { decaying organics (leaves). }\end{array}$ \\
\hline GS12 & $\begin{array}{l}\leq 30 \\
(1 \mathrm{ft})\end{array}$ & - & - & $\begin{array}{l}\text { Soft, greenish-brown, fine grain sand \& } \\
\text { silt (near banks); more gravel in gaster } \\
\text { moving water (near weir). }\end{array}$ \\
\hline GSO7 & - & $(0.75 \mathrm{ft} / \mathrm{s})$ & - & $\begin{array}{l}\text { Sediment was mostly poorly sorted sand } \\
\text { \& gravel with some silty clay. }\end{array}$ \\
\hline $\begin{array}{c}\text { GS08 } \\
\text { (downstream) }\end{array}$ & $\begin{array}{l}30-45 \\
(1-1.5 \mathrm{ft})\end{array}$ & $(0.5 \mathrm{ft} / \mathrm{s})$ & - & $\begin{array}{l}\text { Channel bed mostly gravel. Clayey silt } \\
\text { (brown) near banks. }\end{array}$ \\
\hline \multicolumn{5}{|c|}{$\begin{array}{l}\text { (a) Estimated from sampling method (ponar sampler used when water depth greater than } 30 \\
\mathrm{~cm}[1 \mathrm{ft}] \text { ). } \\
\text { Based on field logs, Sediment Sample Field Records, and personal communication with } \\
\text { Patricia White. }\end{array}$} \\
\hline
\end{tabular}




\section{A.4 DREDGE AND DISPOSE ALTERNATIVE}

The Dredge and Dispose alternative consists of temporary Fishing Advisory/restrictions as discussed in Section A.2, dredging of a preponderance of the contaminated sediment from the slough, and disposal of the dredge material to an on-base landfill. An estimate of the volume of materials to be handled is provided in the following subsection.

\section{A.4.1 Volume of Sediment to be Dredged}

The preponderance of $\mathrm{PCB}$ contamination that would be removed by dredging is located in approximately 300 liner $\mathrm{m}$ (1000 ft) of Garrison Slough immediately upstream of Arctic Avenue (Section A.3). The stream here is estimated to be 2.4 to $3 \mathrm{~m}(8-10 \mathrm{ft})$ wide and containing an estimated 0.3 to $0.6 \mathrm{~m} \mathrm{(1-2} \mathrm{ft)} \mathrm{thick} \mathrm{layer} \mathrm{of} \mathrm{sediment} \mathrm{(Table} \mathrm{A.3).} \mathrm{The} \mathrm{depth} \mathrm{of} \mathrm{contamination} \mathrm{in}$ the slough bottom sediments is unknown. For the purposes of this FS, the PCB contamination is assumed to be uniformly distributed throughout the thickness of the slough sediment. Thus, a conservative estimate of the amount of sediment to be removed assuming a contaminated volume of sediment $300 \mathrm{~m} \times 3 \mathrm{~m} \times 0.6 \mathrm{~m}^{(3)}\left(1000^{\prime} \times 10^{\prime} \times 2^{\prime}\right)$, yields approximately $600 \mathrm{~m}^{3}\left(780 \mathrm{yd}^{3}\right)$.

Assuming a 10 percent over dig, to ensure capture of all contamination, this estimate yields a total sediment volume of $660 \mathrm{~m}^{3}\left(860 \mathrm{yds}^{3}\right)$.

HLA (1989) described the substrate of this portion of Garrison Slough, as being sand and gravel. Observations made during the August 1994 sampling suggest the sediment consists of half gravel and half finer-grained material, with roughly equal amounts of fine sand, silt and clay, and some decayed organic mater. Total organic carbon content was estimated at approximately $1 \%$.

\section{A.4.2 Disposal}

The dredge material $\left(660 \mathrm{~m}^{3}\right.$ [860 cu yd]) would be hauled via dump truck to an on-base landfill. It is assumed the asbestos landfill is available for this purpose. The dredge material would be disposed directly to an unlined trench and covered with native soils. Final closure of the landfill would be conducted per existing plans.

Disposal of dredge material $50 \mathrm{ppm}$ and greater in a method other than in a chemical waste landfill requires the approval of the EPA's regional administrator (EPA, 1990; 40 CFR 761.60[a] [5]). However, the low concentration of PCBs (55 ppm max.), and the inherently low solubility (2.7EE-3 $\mathrm{mg} / \mathrm{L}$ ), and high sorption (as indicated by high octanol-water partitioning $\left[\mathrm{K}_{\mathrm{ow}}=14 \mathrm{EE} 6\right]$ ) of Aroclor1260 (EPA, 1990) indicates that land disposal is a reasonable and prudent option.

\section{A.5 DREDGE AND TREAT ALTERNATIVE}

This alternative consists of temporary fishing restrictions (per Section A.2); sediment removal (temporary surface water diversion and dredging, per Section A.4l; and treatment (land farming) to address source area contaminants.

\section{A.5.1 Land Farming Area}

After the sediment has been removed from the slough, a land farming area with simple components like a liner, piping, and valves would be needed. The actual area needed depends on the amount of sediment removed, the amount of soil amendment to be added, and the spreading thickness. The 
maximum volume of sediment to be removed and assumed to require treatment was about $660 \mathrm{~m}^{3}$ $\left(860 \mathrm{yd}^{3}\right)$. An equal amount $\left(660 \mathrm{~m}^{3}\left[860 \mathrm{yd}^{3}\right]\right)$ of soil amendment (sawdust and straw) is assumed to be required. The required spreading thickness is estimated at $15 \mathrm{~cm}$ each for the soil amendment and the dredge material. Thus, the following estimation was used to determine the size of the land farm area:

$$
\left(2 * 660 \mathrm{~m}_{3}\right) \div(2 * 0.15 \mathrm{~m})=4400 \mathrm{~m}^{2} \approx 66 \mathrm{~m} \times 66 \mathrm{~m}(220 \mathrm{ft} \times 200 \mathrm{ft})
$$

\section{A.5.2 Efficiency}

The amount of PCBs destroyed during land farming was estirnated from the volume of dredge material to be treated, the estimated mass of PCB before treatment, and the estimated average concentration after treatment. The volume of contaminated sediment (to be treated) is estimated at $660 \mathrm{~m}^{3}\left(860 \mathrm{yd}^{3}\right.$ ) (Section A.4).

The estimated mass of PCBs, calculated by summing the mass in each slough sement (Table A.2) between GS41 and Artic Avenue, is approximately $26.6 \mathrm{~kg}$.

Land farming treatment (after 1 to 3 years) is estimated to reduce the concentration of PCBs to $<2$ $\mathrm{ppm}(\mathrm{mg} / \mathrm{kg})$. Thus, the PCB mass after treatment is estimated at:

$$
660 \mathrm{~m}^{3} * 1800 \mathrm{~kg} / \mathrm{m}^{3} *<2 \mathrm{mg} / \mathrm{kg} * \mathrm{~kg} / 10^{6} \mathrm{mg}<2.4 \mathrm{~kg}
$$

This is a reduction of approximately $91 \%$.

\section{A.6 REFERENCES}

DeBoer, J., F. V. Valk, M.A.T. Kerkhoff, P. Hage, U.A.T. Brinkman. 1994. "8-Year Study of the Elimination of PCBs and Other Organochlorine Compounds from Eel (Anguilla anguilla) Under Natural Conditions", In Environ. Sci. Technol; Vol. 28, No. 13, p. 224.2-2248.

Harding Lawson Associates (HLA). 1989. Installation Restoration Program Remedial Investigation/Feasibility Study, Stage 3, Eie/son Air Force Base, Fairbanks, Alaska, Volume II, Draft Remedial Investigation/Feasibility Study (July 1988 to April 1989), Chapter IV, April 1989. (Doc. No. 1360). Administrative Record, Eielson Air Force Base, Fairbanks, Alaska.

Harkeness, M. R., J. B. McDermott, D. A. Abromowicz, J. J. Salvo, W. P. Flanagan, M. L. Stephans, F. J. Mondello, R. J. May, J. H. Lobos, K. M. Carroll, M. J. Brennan, A. A. Bracco, K. M. Fish, G. L. Warner, P. R. Wilson, D. K. Dietrch, D. T. Lin, C. B. Morgan, and W. L. Gately. 1993. "In Situ Stimulation of Aerobic PCB Biodegradation in Hudson River Sediments", In Science; Vol. 259, p. 503-507.

Rhee, G. Y., R. C. Sokol, B. Bush, and C. M. Bethoney. 1993. "Long-Term Study of the Anaerobic Dechlorination of Arochlor 1254 with and without Biphenyl Enrichment". In Environmental Science Technology; Vol. 27, No. 4, p. 714-719. American Chemical Society. 


\section{APPENDIX B}

\section{REMEDIAL ACTION ALTERNATIVE COST ESTIMATES}




\section{CONTENTS}

B. 1 OVERVIEW OF FEASIBILITY COST ESTIMATES $\ldots \ldots \ldots \ldots \ldots \ldots \ldots \ldots \ldots$

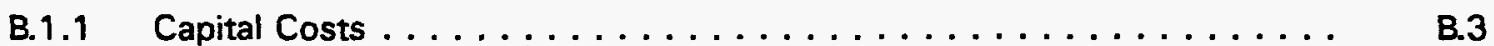

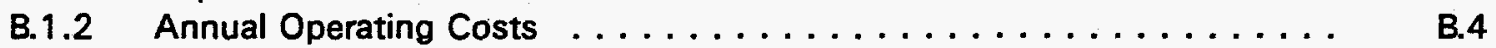

B.1.3 Present Worth Costs . . . . . . . . . . . . . . . . . B.4

B.2 PRESENTATION Of AlteRnATIVE COSTS $\ldots \ldots \ldots \ldots \ldots \ldots \ldots \ldots$ ATTACHMENTS

B.1 No Action Alternative

B.2 Limited Action Alternative

B.3 In Situ Capping Alternative

B.4 Dredge and Disposal Alternative

B.5 Dredge and Treat Alternative 
-

-

- 


\section{APPENDIX B REMEDIAL ACTION ALTERNATIVE COST ESTIMATES}

This appendix presents an order-of-magnitude construction cost estimate for each of the five alternatives described in Section 5.0. Cost is one of the seven criteria to evaluate the alternatives. A summary of the capital costs, annual operation and maintenance $(O \& M)$ costs, and the present worth costs is provided in Table B.1.

\section{B.1 OVERVIEW OF FEASIBILITY COST ESTIMATES}

Cost estimates were prepared using current pricing data, when available, to aid in the evaluation of alternatives. Final project cost will depend on actual labor and material costs, actual site conditions at the time of remediation, productivity, competitive market conditions, final project scope, final project schedule, the firm selected to perform the engineering, and many other variables. As a result, the final project cost will differ from the estimates presented here. Because of the inherent variability, financial needs and resources must be carefully reviewed before decisions are made or final remedial action budgets are estimated.

The cost estimates are order-of-magnitude cost estimates with an intended accuracy of +50 percent and -30 percent. This range applies only to the alternatives as described in Section 5.0 and does not account for major changes in the scope of any alternative. The specific technologies for each alternative were not selected with the intent of limiting flexibility in the remedial approach, but rather to provide a basis for cost estimating. The actual remedial actions and their associated costs will be determined when EPA selects the approach for the final design.

Cost estimates include total capital cost, annual O\&M costs, and total present worth costs for each alternative. Both capital and unit price costs are based on information solicited from Alaska and local contractors and from engineering judgement.

\section{B.1.1 Capital Costs}

Capital costs are the direct and indirect costs required to initiate and install the components of a remedial action. They include only those expenditures needed to design, construct, and install a remedial action. They exclude the costs needed to maintain a remedial action throughout its design life.

Installation costs include items such as costs for construction, site development, and buildings and services. Construction costs include costs needed to prepare for or implement the actions, such as the costs for materials, labor, and equipment. These costs have been adjusted for Alaska wherever possible. Decontamination facilities, health and safety equipnnent, and costs associated with confirmatory sampling have also been included where possible.

Indirect costs consist of engineering, supervision during construction, licenses and permits, and other services necessary to carry out a remedial action. They are not incurred as part of the remedial action but are ancillary to installation and construction costs. Indirect capital costs include bid and scope contingencies that reduce the likelihood of a cost overrun. Bid contingencies cover unknowns associated with the construction of the project, such as material or labor shortages. 
Scope contingencies include provisions for changes that normally occur as part of the final design and implementation. EPA and ADEC administration are also indirect costs, but they have not been included in the cost estimate.

\section{B.1.2. Annual Operating Costs}

Annual operating costs for a remedial action include the costs incurred each year following construction or installation of a project. For the purposes of the economic evaluation, they are assumed to be paid at the end of the year in which they occur.

\section{B.1.3 Present Worth Costs}

Annual O\&M costs occur over different periods of time for different alternatives. Present worth analyses provide a method for comparing costs that occur over different periods of time by discounting future costs to the present year. Present worth calculations were based on a maximum 30 -year period. O\&M costs that are incurred beyond the 30 -year period become insignificant in the present worth analysis. The present worth analyses were calculated assuming 3,5 , and 10 percent interest rates in order to provide a range of values. Future costs are not escalated for inflation.

\section{B.2 PRESENTATION OF ALTERNATIVE COSTS}

The estimated costs calculated for each alternative are presented in the following attachments:

Attachment B.1 Attachment B.2 Attachment B.3 Attachment B.4 Attachment B.5
No Action Alternative Limited Action Alternative In Situ Capping Alternative Dredge and Disposal Alternative Dredge Treat Alternative 


\section{ATTACHMENT B.1. NO ACTION ALTERNATIVE ORDER OF MAGNITUDE COST ESTIMATE}

Description:

Requires no action. But does include routine monitoring and sampling of the fish and sediment concentrations.

\section{Cost Component Description}

CAPITAL COSTS

A) Fish Remediation No Action Required

B) Sediment Remediation

No Action Required

CONSTRUCTION COST SUBTOTAL

Mobilization and \& Gen'l Reqm'ts @15\%

CONSTRUCTION COST SUBTOTAL

Contingencies

Bid Contingency@10\%

Scope Contingency @ 20\%

\section{Quantity Unit $\underline{\text { Pnice }} \frac{\text { Component }}{\underline{\text { Cost }}} \frac{\underline{\text { Category }}}{\underline{\text { Subtotal }}}$ \\ Quantity Unit $\underline{\text { Pnice }} \frac{\text { Component }}{\underline{\text { Cost }}} \frac{\underline{\text { Category }}}{\underline{\text { Subtotal }}}$}

Other Costs

Administrative @ 5\%

Services During Construction @ 10\%

Legal @ 5\% 
ATTACHMENT B.1. (Contd)

\section{Cost Component Description \\ Unit Component Category Quantity Unit Price}

\section{PRESENT WORTH COSTS}

PRESENT WORTH OF OPERATIONS \& MAINTENANCE COSTS

Present Worth of Fish Remediation O \& M Costs for Years 1-30

Assuming annual cost for 1-30 years@

Assuming annual cost for 1-30 years @

$3 \%$

$5 \%$

$10 \%$

resent Worth of Sediment Remediation O \& M Costs for Years 1-30

Assuming annual cost for 1-30 years@

Assuming annual cost for 1-30 years@

Assuming annual cost for 1-30 years @

PRESENT WORTH OF MONITORING COSTS

Present Worth of Fish Monitoring Costs for Years 1-30

Assuming annual cost for 1-30 years@

Assuming annual cost for 1-30 years @

Assuming annual cost for 1-30 years @

Present Worth of Sediment Monitoring Costs for Years 1-30

Assuming annual cost for 1-30 years @

Assuming annual cost for 1-30 years @

Assuming annual cost for $1-30$ years @

$\begin{array}{rr}3 \% & \$ 0 \\ 5 \% & \$ 0 \\ 10 \% & \$ 0\end{array}$

$\begin{array}{rr}3 \% & \$ 50,961 \\ 5 \% & \$ 39,968 \\ 10 \% & \$ 24,510\end{array}$

$3 \%$

$\$ 74,482$

$\$ 58,415$

$\$ 35,822$

$\$ 0$

\begin{tabular}{rr|}
$3 \%$ & $\$ 125,443$ \\
$5 \%$ & $\$ 98,384$ \\
$10 \%$ & $\$ 60,332$
\end{tabular}

The cost estimates shown have been prepared for guidance in project evaluation and implementation form the information available at the time of the estimate. Final project costs will depend on actual labor and material costs, actual site condition $s$ at the time of remediation, productivity, competitive market conditions, final project scope, final project schedule, the firm selected to perform the engineering, and many other variables. As a result, the final project costs will differ from the estimates presented here. Because of the inherent variability, project feasibility and funding needs must be carefully reviewed prior to making specific financial decisions to help ensure proper project evaluation and adequate funding. 


\section{ATTACHMENT B.2. LIMITED ACTION ALTERNATIVE ORDER OF MAGNITUDE COST ESTIMATE}

\section{Description:}

A fishing advisory/restrictions would be promulgated by the Alaska Department of Fish and Game. Cost to the Air Force is assumed to be negligible.

A dam of 4"-2' rock would be constructed to allow water flow and prevent fish migration. The dam will be $4^{\prime}$ thick at the top with side sloping at $45 \mathrm{deg}$. On the down stream side there will be a $4^{\prime}$ shelf $11 / 2^{\prime}$ thick to prevent erosion.

\section{Basis:}

The total rock volume of the dam (assuming a 10' wide stream) is $12 \mathrm{cu}$. yd. An additional $15 \mathrm{cu}$. yd of smaller rock will be laid to cover the bank above and below the dam to prevent wash out. Assumes the dam can be constructed during low water without diverting the stream or using other sediment controls. The dam can be constructed with a backhoe from the stream bank to maneuver the rocks.

\section{Cost Component Description}

\section{CAPITAL COSTS}

A) Fish Remediation

Fishing Advisory/Restrictions

No Action Required

Fish Control Dam

Site Preparation

4' - 6" Rock (delivered)

Dam Construction

2" - 4" Rock (delivered)

Bank Stabilization Rock

B) Sediment Remediation

No Action Required

CONSTRUCTION COST SUBTOTAL

Mobilization and \& Gen'l Reqm'ts @15\%

CONSTRUCTION COST SUBTOTAL

Contingencies

Bid Contingency@10\%

Scope Contingency@20\%

Other Costs

Administrative@ @\%

Services During Construction @ 10\%

Legal @ 5\%

IMPLEMENTATION COST TOTAL Engineering/Design @15\%
Unit Component Quantity Unit Price

$\begin{array}{rrrr}0 & & 0 & 0 \\ & & & \\ 8 & \text { HR } & 179 & 1532 \\ 12 & \text { YD } & 30 & 360 \\ 8 & \text { HR } & 179 & 1432 \\ 15 & \text { YD } & 30 & 450 \\ 8 & \text { HR } & 179 & 1432 \\ & & & \\ & 0 & & 0\end{array}$

0 
ATTACHMENT B.2. (Contd)

\section{Cost Component Description}

ANNUAL OPERATIONS \& MAINTENANCE COST

A) Fish Remediation (Years 1-30)

Fishing Advisory/Restrictions (Yearly)

No Action Required

Fish Control Dam

Monthly Monitoring

Annual maintenance

B) Sediment Remediation (Years 1-30)

No Action Required
Unit Component Quantity Unit Price $\frac{\text { Cost }}{\text { Subtotal }}$
$\$ 2,032$

$\begin{array}{rrrr}0 & & 0 & 0 \\ 12 & \text { HR } & 50 & 600 \\ 8 & \text { HR } & 179 & 1432 \\ 0 & & 0 & 0\end{array}$

0

ANNUAL OPERATIONS \& MAINTENANCE COST TOTAL

ANNUAL MONITORING COST

A) Fish Remediation (Years 1-30)

Fish Sample Analyses (Yearly)

Collection, Data Management \& Reporting (Yearly)

B) Sediment Remediation (Years 1-30)

Sediment Sample Analyses (Yearly)

Collection, Data Management \& Reporting (Yearly)

600

40 HR $50 \quad 2000$

12 EA $150 \quad 1800$

$\$ 3,800$

40 HR 50

2000

ANNUAL MONITORING COST TOTAL

$\$ 6,400$

\section{PRESENT WORTH COSTS}

PRESENT WORTH OF OPERATIONS \& MAINTENANCE COSTS

Present Worth of Fish Remediation $O \&$ M Costs for Years 1-30

Assuming annual cost for 1-30 years @

Assuming annual cost for $1-30$ years @

Assuming annual cost for $1-30$ years @

Present Worth of Sediment Remediation O \& M Costs for Years 1-30

Assuming annual cost for $1-30$ years @

Assuming annual cost for $1-30$ years @

Assuming annual cost for 1-30 years @

\section{PRESENT WORTH OF MONITORING COSTS}

Present Worth of Fish Monitoring Costs for Years 1-30

Assuming annual cost for $1-30$ years @

Assuming annual cost for 1-30 years @

Assuming annual cost for 1-30 years @

Present Worth of Sediment Monitoring Costs for Years 1-30

Assuming annual cost for $1-30$ years @ 
ATTACHMENT B.2. (Contd)

TOTAL PRESENT WORTH (CAPITAL + O\&M + MONITORING COSTS)

Assuming 30 years @

$3 \%$

$\$ 175,598$

Assuming 30 years @

$5 \%$

$\$ 139,948$

Assuming 30 years@

$10 \%$

$\$ 89,815$

The cost estimates shown have been prepared for guidance in project evaluation and implementation form the information available at the time of the estimate. Final project costs will depend on actual labor and material costs, actual site condition s at the time of remediation, productivity, competitive market conditions, final project scope, final project schedule, the firm selected to perform the engineering, and many other variables. As a result, the final project costs will differ from the estimates presented here. Because of the inherent variability, project feasibility and funding needs must be carefully reviewed prior to making specific financial decisions to help ensure proper project evaluation and adequate funding. 


\section{ATTACHEMENT B.3. \\ IN SITU CAPPING ALTERNATIVE ORDER OF MAGNITUDE COST ESTIMATE}

\section{Description:}

A fishing advisory/restrictions would be promulgated by the Alaska Department of Fish and Game.

Cost to the Air Force is assumed to be negligible.

The contaminated area would be isolated by installing temporary dams above and below the contaminated area. The stream flow would be pumped around the isolated area and the area pumped out to facilitate work in the stream bed. The steam bed is near ground water level so continued pumping may be required. The stream bed would be covered with a porous liner and successive layers of sand, gravel, and rock. The bottom of the stream bed will be raised 12-18".

\section{Basis:}

Assumes local material can be used for dam construction. Assumes the slough bed can be sufficiently pumped to allow access with a front end loader and hand contouring. The porous liner will retain the sediment and still allow any gases formed during decomposition of organic material to escape and not "lift" the bed. Liner area and rock requirements are based on half-round stream bed $12^{\prime}$ wide. Over liner will be spread: $6^{\prime \prime}$ of pea gravel, 6 " of $2^{\prime \prime}$ drain rock, and $6^{\prime \prime}$ of $2^{\prime \prime}-6^{\prime \prime}$ rock.

\section{Cost Component Description}

CAPITAL COSTS

A) Fish Remediation

Fishing Advisory/Restrictions

No Action Required

B) Sediment Remediation

Dam Construction \& Stream Diversion

Dam Construction

Hydraulic Pumps (1700 gpm; trailer mounted)

3 req'd - monthly rental.

8" PVC Pipe

Pipe Installation

Lining Installation

Bed Preparation (Loader plus 3 men)

Geotextile Liner

Liner Installation

Pea Gravel (delivered)

Gravel Contouring

Small Rock (delivered)

Rock Contouring

Large Rock

Rock Contouring

CONSTRUCTION COST SUBTOTAL

Mobilization and \& Gen'l Reqm'ts @15\%
Unit Component Category

\section{Quantity Unit Price $\underline{\text { Cost }}$ Subtotal}

\begin{tabular}{rrrrrr}
0 & & 0 & 0 & \\
& & & & $\$ 91,789$ \\
16 & HR & 179 & 2964 & \\
3 & MO & 1050 & 3150 & \\
& & & & \\
2200 & LF & 16 & 35222 & \\
16 & HR & 49 & 784 & \\
& & & & \\
16 & HR & 179 & 2964 & \\
20000 & SF & 1 & 20000 & \\
8 & HR & 179 & 1432 & \\
195 & YD & 25 & 4875 & \\
24 & HR & 179 & 4396 & \\
195 & YD & 18 & 3510 & \\
24 & HR & 179 & 4296 & \\
195 & YD & 20 & 3900 & \\
24 & HR & 179 & 4296 & \\
\cline { 4 - 4 } & & & & $\$ 91,789$ \\
& & & & $\$ 13,768$
\end{tabular}

FINAL 
ATTACHMENT B.3. (Contd)

\author{
Cost Component Description \\ CONSTRUCTION COST SUBTOTAL \\ Contingencies \\ Bid Contingency @ 10\% \\ Scope Contingency @ 20\% \\ Other Costs \\ Administrative@ @\% \\ Services During Construction @ 10\% \\ Legal @ 5\% \\ IMPLEMENTATION COST TOTAL \\ Engineering/Design@15\%
}

CAPITAL COST TOTAL
Unit Component Category

Quantity Unit Price

Subtotal

$\$ 105,557$

$10 \%$

$20 \%$

$\$ 10,556$

$\$ 21,111$

$5 \%$
$10 \%$
$5 \%$

$15 \%$

$\$ 5,278$

$\$ 10,556$

$\$ 5,278$

$\$ 158,336$

$\$ 23,750$

$\$ 182,086$

ANNUAL OPERATIONS \& MAINTENANCE COST

A) Fish Remediation (Years 1-8)

No Action Required

0

$12 \mathrm{HR} \quad 50$

8 HR 179

Annual maintenance

B) Sediment Remediation (Years 1-30)
Monthly Monitoring
$\$ 0$

0

$\$ 2,132$

600

1532

ANNUAL OPERATIONS \& MAINTENANCE COST TOTAL

\section{ANNUAL MONITORING COST}

A) Fish Remediation (Years 1-8)

Fish Sample Analyses (Yearly)

Collection, Data Management \& Reporting (Yearly)

B) Sediment Remediation (Years 1-30)

Sediment Sample Analyses (Yearly)

Collection, Data Management \& Reporting (Yearly)

ANNUAL MONITORING COST TOTAL

4 EA 150

40 HR 50

12 EA 150

40 HR 50
$\$ 2,600$

600

2000

$\$ 3,800$

1800

2000

\section{PRESENT WORTH COSTS}

PRESENT WORTH OF OPERATIONS \& MAINTENANCE COSTS

Present Worth of Fish Remediation O \& M Costs for Years 1-8

Assuming annual cost for 1-8 years @

Assuming annual cost for $1-8$ years @

$3 \%$

$\$ 0$

Assuming annual cost for 1-8 years @

Present Worth of Sediment Remediation O \& M Costs for Years 1-30

Assuming annual cost for $1-30$ years @

Assuming annual cost for 1-30 years @

Assuming annual cost for $1-30$ years @ 
ATTACHMENT B.3. (Contd)

Cost Component Description

Quantily Unit

Unit Component

Category

PRESENT WORTH OF MONITORING COSTS

Present Worth of Fish Remediation O \& M Costs for Years 1-8

Assuming annual cost for 1-8 years @

Assuming annual cost for 1-8 years @

$3 \%$

$\$ 18,251$

Assuming annual cost for 1-8 years @

$5 \%$

$\$ 16,804$

$10 \%$

$\$ 13,871$

Present Worth of Sediment Remediation O \& M Costs for Years 1-30 Assuming annual cost for $1-30$ years @ Assuming annual cost for 1-30 years@

$\$ 74,482$

$5 \%$

$\$ 58,415$

Assuming annual cost for $1-30$ years @

$10 \%$

$\$ 35,822$

ESTIMATED CAPITAL COST (from above)

$\$ 182,086$

TOTAL PRESENT WORTH OF CAPITAL COST \& OPERATIONS \& MAINTENANCE COST

Assuming 30 years @

Assuming 30 years @

$3 \%$

$5 \%$

Assuming 30 years @

$10 \%$

The cost estimates shown have been prepared for guidance in project evaluation and implementation form the information available at the time of the estimate. Final project costs will depend on actual labor and material costs, actual site condition s at the time of remediation, productivity, competitive market conditions, final project scope, final project schedule, the firm selected to perform the engineering, and many other variables. As a result, the final project costs will differ from the estimates presented here. Because of the inherent variability, project feasibility and funding needs must be carefully reviewed prior to making specific financial decisions to help ensure proper project evaluation and adequate funding. 


\section{ATTACHMENT B.4. \\ DREDGE AND DISPOSE ALTERNATIVE ORDER OF MAGNITUDE COST ESTIMATE}

Description:

Fishing advisory/restrictions would be promulgated by the Alaska Department of Fish and Game.

Cost to the Air Force is assumed to be negligible.

Sediment would be removed from the slough and buried on site. Temporary dams would be constructed above and below the primary contamination area. Surface water (currently flowing at 4 $10 \mathrm{cfs}$ ) would be pumped around the $1000 \mathrm{ft}$ area targeted for remediation. The steam bed would then be dredged to a depth of 1-2 ft with a trackhoe. The sediment would then be trucked to the disposal area. A disposal trench to would be excavated to hold the estimated $860 \mathrm{yd}^{3}$ of dredge material. The sediment would be dumped in the disposal trench and covered with 1 ' of native soil, and the area with reseeded with grass.

\section{Basis:}

Total material to be dredged is assumed to be $780 \mathrm{yd}^{3}$ plus $10 \%$ overdig $\left(860 \mathrm{yd}^{3}\right)$. It is assumed that an acceptable disposal area is already on site, and that there are no costs for disposal except for excavation necessary to use site. The clean soil from excavation of the disposal trench would be spread over the contaminated soil and planted w/ grass.

\section{Cost Component Description}

\section{CAPITAL COSTS}

A) Fish Remediation

Fishing Advisory/Restrictions

No Action Required

B) Sediment Remediation

Dam Construction \& Stream Diversion

Dam Construction

Backhoe Mobilization

Hydraulic Pumps (1700 gpm; trailer mounted)

3 req'd - monthly rental.

8". PVC Pipe

Pipe Installation

Dredging \& Material Testing

Excavator \& Operator ( $150 \mathrm{cu}$ yd/day)

Excavator Mobilization/Demobilization

Bulk Material Sampling (Screening -1.1/truck)

Haulage of Dredge Material

Truck and Operator (3)

Disposal

Bulldozer Mobilization

Excavate Trench \& Cover Dredgings

Prepare area for reseeding

Tractor Mobilization

Hydroseeding
Unit Component

\section{Quantity Unit Price \\ Subtotal}

\section{Ouantily Unit Price Cost}

$\begin{array}{rrrrr}0 & & 0 & 0 & \$ 82,584 \\ 16 & \text { HR } & 179 & 2864 \\ 1 & \text { EA } & 100 & 100 \\ 3 & \text { MO } & 1050 & 3150 \\ & & & & \\ 2200 & \text { LF } & 16 & 35222 \\ 16 & \text { HR } & 49 & 784 \\ & & & & \\ 48 & \text { HR } & 155 & 7440 \\ 2 & \text { EA } & 500 & 1000 \\ 100 & \text { EA } & 60 & 6000 \\ & & & \\ 96 & \text { HR } & 65 & 6240 \\ & & & & \\ 1 & \text { EA } & 500 & 500 \\ 56 & \text { HR } & 224 & 12544 \\ 8 & \text { HR } & 50 & 400 \\ 1 & \text { EA } & 100 & 100 \\ 50,000 & \text { SF } & 0.08 & 4000\end{array}$

FINAL 
ATTACHMENT B.4. (Contd)

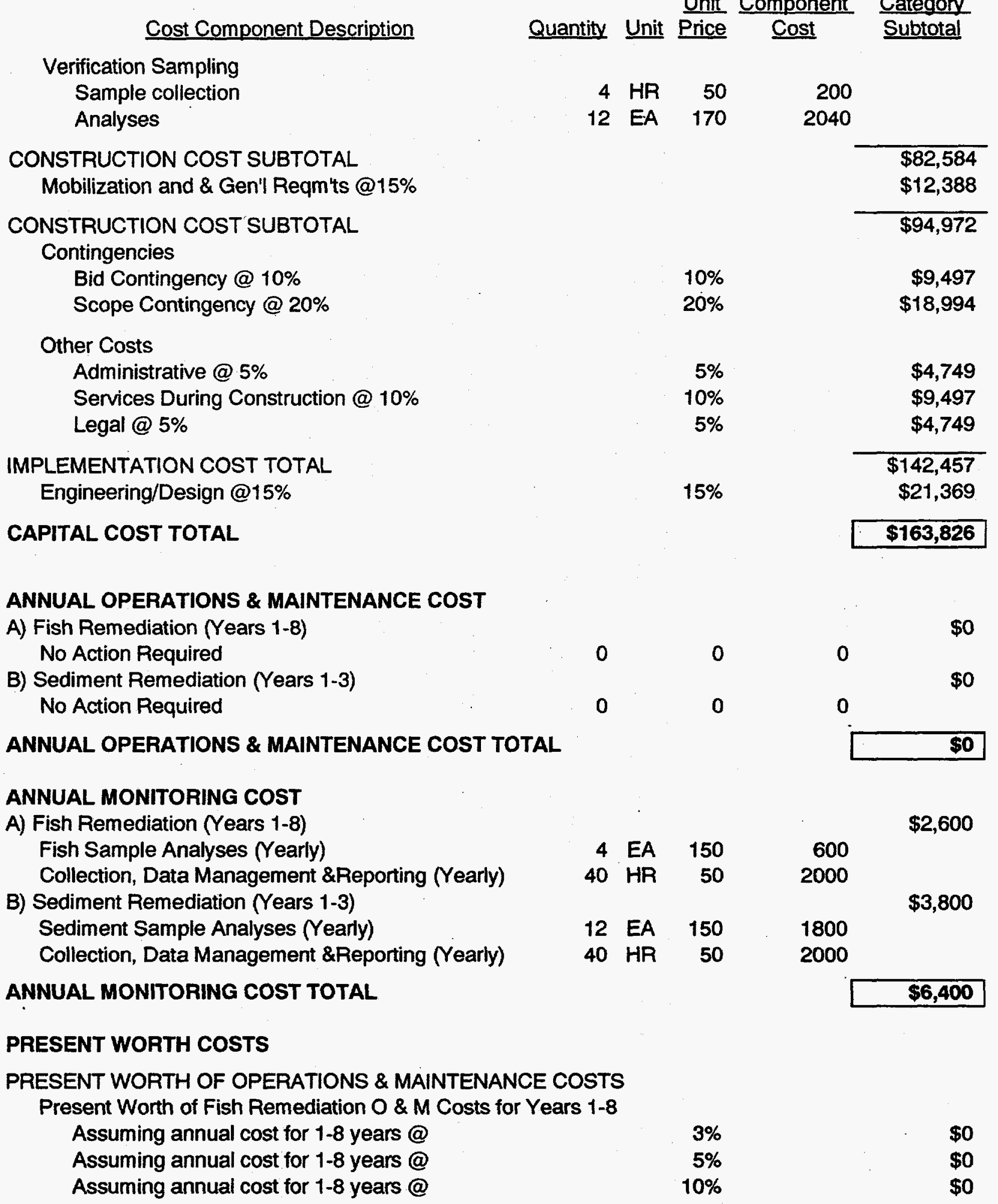


ATTACHMENT B.4. (Contd)

\section{Cost Component Description}

Present Worth of Sediment Remediation O \& M Costs for Years 1-3 Assuming annual cost for 1-3 years @ Assuming annual cost for 1-3 years @ Assuming annual cost for 1-3 years@

\section{PRESENT WORTH OF MONITORING COSTS}

Present Worth of Fish Monitoring Costs for Years 1-8

Assuming annual cost for 1-8 years @ Assuming annual cost for 1-8 years @ Assuming annual cost for 1-8 years @

Present Worth of Sediment Monitoring Costs for Years 1-3

Assuming annual cost for 1-3 years @ Assuming annual cost for $1-3$ years@ Assuming annual cost for 1-3 years @ $\frac{\text { Unit }}{\text { Price }} \frac{\text { Component }}{\text { Costegory }}$ Quantity Unit Price $\frac{\text { Cost }}{\text { Subtotal }}$

ESTIMATED CAPITAL COST (from above)

$\begin{array}{rr}3 \% & \$ 18,251 \\ 5 \% & \$ 16,804 \\ 10 \% & \$ 13,871 \\ & \\ 3 \% & \$ 10,749 \\ 5 \% & \$ 10,348 \\ 10 \% & \$ 9,450\end{array}$

TOTAL PRESENT WORTH OF CAPITAL COST \& OPERATIONS \& MAINTENANCE COST

Assuming 30 years @

Assuming 30 years @

$3 \%$

$5 \%$

$10 \%$

$\$ 163,826$

Assuming 30 years @

The cost estimates shown have been prepared for guidance in project evaluation and implementation form the information available at the time of the estimate. Final project costs will depend on actual labor and material costs, actual site condition $s$ at the time of remediation, productivity, competitive market conditions, final project scope, final project schedule, the firm selected to perform the engineering, and many other variables. As a result, the final project costs will differ from the estimates presented here. Because of the inherent variability, project feasibility and funding needs must be carefully reviewed prior to making specific financial decisions to help ensure proper project evaluation and adequate funding. 


\section{ATTACHMENT B.5. DREDGE AND TREAT ALTERNATIVE ORDER OF MAGNITUDE COST ESTIMATE}

\section{Description:}

Fishing advisory/restrictions would be promulgated by the Alaska Department of Fish and Game. Cost to the Air Force is assumed to be negligible.

Sediment would be removed from the slough and biologically treated on site, via land farming. Temporary dams would be constructed above and below the primary contamination area. Surface water (assumed to flow at 4-10 cfs) would be pumped around the $790 \mathrm{ft}$ area targeted for remediation. The steam bed would be dredged to a depth of 1-2 ft with a backhoe, and the sediment trucked to the treatment area. Soil amendments of straw, saw dust, and/or wood residues would be spread to thickness of about 6 inches over the treatment area. The dredged sediment would then be spread over the soil amendments and inoculated with white rot fungus, Phanerocheate Chrysosporium, and nutrients. The sediment, amendments, and nutrients would be tilled until evenly mixed.

\section{Basis:}

Total material to be dredged is assumed to be $580 \mathrm{yd}^{3}$ plus $10 \%$ overdig $\left(640 \mathrm{yd}^{3}\right)$. The saturated dredged sediment is assumed to contain $30 \%$ moisture. Density is $2877 \mathrm{lbs} / \mathrm{yd}^{3}$. Inoculum and nutrients must be added yearly (worst case). It is assumed that an acceptable treatment area is already on site, and that there are no added costs to use the site except for any necessary grading. The inoculum must be shipped from Utah in drums @ $40 \mathrm{lbs} / \mathrm{ft}^{3}$ and is applied at a rate of $1 \mathrm{yd} / 100$ $\mathrm{yd}^{3}$ sediment; nutrient addition is ammonium nitrate @ $1 \mathrm{lb} / 200 \mathrm{ft}^{2}$. Assumes treated soil can be left

\section{Cost Component Description}

Unit Component

Category

\section{CAPITAL COSTS}

A) Fish Remediation

Quantity Unit Price $\underline{\text { Cost }}$ Subtotal

Fishing Advisory/Restrictions

No Action Required

B) Sediment Remediation

Dam Construction \& Stream Diversion

Dam Construction

Backhoe Mobilization

Hydraulic Pumps (1700 gpm; trailer mounted)

3 req'd - monthly rental.

8" PVC Pipe

Pipe Installation

Dredging \& Material Testing

Excavator \& Operator

Excavator Mobilization/Demobilization

Bulk Material Sampling (Screening -1.1/truck)

Haulage of Dredge Material

Truck and Operator (3)

Verification Sampling

Sample collection

Analyses

$\begin{array}{rrrr}0 & & 0 & 0 \\ & & & \\ 16 & \text { HR } & 179 & 2864 \\ 1 & \text { EA } & 100 & 100 \\ 3 & \text { MO } & 1050 & 3150 \\ & & & \\ 200 & \text { LF } & 16 & 35222 \\ 16 & \text { HR } & 49 & 784 \\ & & & \\ 48 & \text { HR } & 155 & 7440 \\ 2 & \text { EA } & 500 & 1000 \\ 100 & \text { EA } & 60 & 6000 \\ & & & \\ 96 & \text { HR } & 65 & 6240 \\ & & & \\ 4 & \text { HR } & 50 & 200 \\ 12 & \text { EA } & 170 & 2040\end{array}$

FINAL 
ATTACHMENT B.5. (Contd)

\section{Cost Component Description}

Land Farming Biological Treatment

Level and Till Treatment Area

(included Tractor \& Operator)

Tractor Mobilization

Sawdust Soil Amendment (600 yd3, delivered)

Spread and Level Amendment (via Tractor)

Spread and Level Dredged Sediment

Nutrient and Inoculum Addition (Included in O\&M Costs)

CONSTRUCTION COST SUBTOTAL

Mobilization and \& Gen'l Reqm'ts @15\%

CONSTRUCTION COST SUBTOTAL

Contingencies

Bid Contingency@10\%

Scope Contingency @ 20\%

Other Costs

Administrative@ @\%

Services During Construction @ 10\%

Legal @ 5\%

IMPLEMENTATION COST TOTAL

Engineering/Design @15\%

CAPITAL COST TOTAL
Unit Component

Quantity Unit

8 HR

1 EA 100

20 TL 180

8 HR 50

8 HR 50

Cost
400

100

3600

400

400
Categon Subtotal

\section{ANNUAL OPERATIONS \& MAINTENANCE COST}

A) Fish Remediation (Years 1-8)

No Action Required

$10 \%$

$20 \%$

$\begin{array}{r}\$ 69,940 \\ \$ 10,491 \\ \hline \$ 80,431 \\ \$ 8,043 \\ \$ 16,086 \\ \\ \$ 4,022 \\ \$ 8,043 \\ \$ 4,022 \\ \hline \$ 120,647 \\ \$ 18,097 \\ \hline \$ 138,743 \\ \hline\end{array}$

B) Sediment Remediation (Years 1-3)

Treatment Testing of Dredge Spoils (Years 1-3)

Sample collection

Analyses

Nutrient and Inoculum Addition (Years 1-3)

Spread. Nutrients and Inoculum, and Till (disk)

Tractor (w/Disk) Mobilization

Inoculum

Inoculum Shipping (Freight for 25 drums)

Nutrients (Ammonium Nitrate)

0

$5 \%$

$10 \%$

$5 \%$

$15 \%$

0

4 HR 50

6 EA 150

8 HR 50

1 EA 100

6 CY 2500

1000 LB 2

200
$\$ 0$

$\$ 18,700$

200

900

400

100

15000

2000

100

ANNUAL OPERATIONS \& MAINTENANCE COST TOTAL

$\$ 18,700$

$\$ 2,600$

$\begin{array}{rlr}4 & \text { EA } & 150 \\ 40 & \text { HR } & 50 \\ & & \\ 12 & \text { EA } & 150 \\ 40 & \text { HR } & 50\end{array}$

600

2000

1800

2000
$\$ 3,800$

$\$ 6,400$

ANNUAL MONITORING COSTS TOTAL 
ATTACHMENT B.5. (Contd)

\section{Cost Component Description \\ Quantity Unit $\underline{\text { Unit }} \frac{\text { Component }}{\underline{\text { Cost }}} \frac{\text { Categony }}{\underline{\text { Subtotal }}}$}

\section{PRESENT WORTH COSTS}

PRESENT WORTH OF OPERATIONS \& MAINTENANCE COSTS

Present Worth of Fish Remediation O \& M Costs for Years 1-8

Assuming annual cost for 1-8 years @

Assuming annual cost for 1-8 years @

Present Worth of Sediment O\&M Costs for Years 1-3

Assuming annual cost for 1-3 years @

Assuming annual cost for 1-3 years @

Assuming annual cost for 1-3 years @

PRESENT WORTH OF MONITORING COSTS

Present Worth of Fish Monitoring Costs for Years 1-8

Assuming annual cost for $1-8$ years @

Assuming annual cost for $1-8$ years @

Assuming annual cost for 1-8 years @

Present Worth of Sediment Monitoring Costs for Years 1-3

Assuming annual cost for 1-3 years@

Assuming annual cost for 1-3 years @

Assuming annual cost for $1-3$ years @
$3 \%$

$5 \%$

$10 \%$

$3 \%$

$5 \%$

$10 \%$

$\$ 0$

$\$ 0$

$\$ 0$

$\$ 52,895$

$\$ 50,925$

$\$ 46,504$

$\$ 18,251$

$\$ 16,804$

$\$ 13,871$

$5 \%$

$\$ 10,749$

$\$ 10,348$

$\$ 9,450$

$\$ 138,743$
$5 \%$

$10 \%$

ESTIMATED CAPITAL COST (from above)

\section{TOTAL PRESENT WORTH OF CAPITAL COST \& OPERATIONS \& MAINTENANCE COST \\ Assuming 30 years @ \\ Assuming 30 years @ \\ Assuming 30 years @ \\ $3 \%$ \\ $5 \%$ \\ $10 \%$ \\ $\$ 220,638$ \\ $\$ 216,821$ \\ $\$ 208,568$}

The cost estimates shown have been prepared for guidance in project evaluation and implementation form the information available at the time of the estimate. Final project costs will depend on actual labor and material costs, actual site condition $s$ at the time of remediation, productivity, competitive market conditions, final project scope, final project schedule, the firm selected to perform the engineering, and many other variables. As a result, the final project costs will differ from the estimates presented here. Because of the inherent variability, project feasibility and funding needs must be carefully reviewed prior to making specific financial decisions to help ensure proper project evaluation and adequate funding. 
PNL-10839

UC-602

\section{Distribution}

No. of

Copies

OFFSITE

P. J. White

Marine Sciences Laboratory 1529 W. Sequim Bay Road

Sequim, WA 98382
No. of

Copies

ONSITE

17 Pacific Northwest Laboratory

L. M. Bagaasen

P7-43

G. B. Josephson

P7-41

D. L. Lanigan

K9-48

G. V. Last (5)

K9-48

R. E. Lewis

K9-48

R. M. Smith

K6-96

Information Release Office (7)

K1-06

Distr.1 